\title{
LVI. JAPAN.
}

15 September 161\%. ${ }^{1}$

Specx werd als chef der Nederlandsche factorij te Hirado opgevolgd door Hendrik Brouwer (1613), om dezen laatsten echter weder in 1614 te vervangen. Hij bleef de zaken leiden tot 1621. In den tijd van Speex's tweede verblijf in Japan, overleed (1616) Iyeyasoe en werd opgevolgd door zijn zoon Hidetada. Deze hernieuwde in 1617 den handelspas voor de Compagnie. (Vgl. Nachod, Japan, S. 149-172, XLIX f.; Kämpfer, Japan, bldz. 272 en Tafel XX).

Wanneer Hollandsche handelsschepen, als zij op Japan varen, opzettelijk of omdat zij moeijelijkheden ten gevolge van wind en golven ontmoeten, aan eene plaets, waar het ook zij, ${ }^{2}$ binnen het rijk Nippon ${ }^{3}$ landen, zoo zal men - kort af gezegd - hen niet te keer gaan.

Het $3^{\text {de }}$ jaar Genkwa

op den $16^{\text {den }}$ dag van de $8^{\text {ste }}$ maand,

(15 van Herfstmaand 1617) aan

\author{
Zegel \\ van den Sjoogoen \\ Minamoto Fidetada. ${ }^{5}$
}

\section{Henreika Forrowaro. ${ }^{4}$}

\section{BANDA.}

\section{Juni (?) 1618. ${ }^{6}$}

In Juni 1617 had de G.G. Laurens Reael de Banda-groep weder verlaten. De Engelschen waren op poeloe Nailaka, bij Roen, gebleven. Reael kwam in Maart 1618 terug. In dien tusschentijd waren de Lontoreezen op Groot-Banda weder met ons op vijandigen voet gekomen tengevolge van hoogere eischen, door onzen gouverneur op Banda aan de Bandaneezen gesteld ten aanzien der muskaatnoten-levering: een vijandschap, door de Engelschen gesteund. Een poging, om Lontor te veroveren, mislukte aan de onzen. Reael sloot toen een nieuw contract met de ons toen niet vijandig gezinde, althans niet openlijk vijandig gezinde, negerijen van Groot-Banda en met Rosengain. (Vgl. Tiele, Europeërs, IX, bldz. 200-202). ?

1 Overgenomen uit Lauts, Japan, bldz. 181 (noot 2): "De goedheid van het Ministerie van Koloniën stelt $\mathrm{mij}$ in staat de vertaling van deze pas te geven", zegt Lauts.

2 Dit verlof is hier opmerkelijk, omdat juist in dezen tijd overigens de handel van vreemdelingen beperkt was geworden tot Nagasaki en Hirado.

3 Inheemsche naam voor Japan.

4 Hendrik Brouwer zal dit moeten zijn. De Japansche autoriteiten vergisten zich dus in het adres. (Vgl. Nachod, S. $171 \mathrm{f}$., L.)

${ }^{5}$ Hidetada.

6 Uit het Contractboek.

${ }^{2}$ Van der Chijs, Banda-eilanden, heeft dit contract niet overgenomen. 
Accoordt, gemaeckt tusschen de Bandaneezen van Salamme ${ }^{1}$ ende de plaetse onder haer sorterende, ${ }^{2}$ als namentlijck Waijer, Dener ${ }^{3}$, Rossingeijn ende wadt(? $)^{4}$ hun ende den erentfesten gestrenge $\mathrm{Ed}^{\mathrm{en}} \mathrm{H}^{\mathrm{re}}$ Lourents Reael, gouvern ${ }^{\mathrm{r}}$ gener $^{\mathrm{l}}$ over de Oostjndien wegen de Mogende $\mathrm{H}^{\text {ren }}$ Staten Gener der Vereenighde Nederlantsche provintien, Sijn Princel. Ex ${ }^{\text {tie }}$ ende de $\mathrm{H}^{\mathrm{ren}}$ Bewinthebberen der Vereenighde Oostindische Compe

Eerstelijck de orangcays en principale van Salamme uyt de name van alle de boven verhaellde plaetsen zijn ende hebben geaccordeert met den bovengenoemden $\mathrm{Ed}^{\mathrm{e}} \mathrm{H}^{\mathrm{r}}$ Lourens Reael, namentlijck dat van beijde zijden ende elck van hun jnt bijsonder vergeven, dooden, ende doen te niete mits desen alle de voorgaende questies, hostiliteyten ende oneenigheden jn voorleden tijde met den anderen gehadt.

De voorschreven Bandaneesen sullen gehouden zijn, hare vrughten, te weten foelie, nooten ende andersints op 't eylandt Nera om te verkopen brengen ende aen de commies van de Vereenighde Comp ${ }^{\mathrm{e}}$ in een huys, daertoe buyten t' fordt gemaeckt, leveren, ongehouden zijnde, ten ware met haer belieffte, jnt fordt te komen ende om voor te komen alle discontentemendten van beyde zijde zullen de voorschreven Bandaneesen alltijt goede foelye ende nooten brengen ende soo contrarie bevonden wordt, sall den commies deselve in arrest mogen houden, mits dat hij daervan aen die van Salemme zall verwittigen, opdat zij neffens de president offte overste van wegen de Hoogmogende $\mathrm{H}^{\text {ren }}$ Staten Gener ${ }^{l}$ over dese eylanden van Banda naer geleegenth ${ }^{t}$ van zaeken mogen disponeren.

Eenige Bandaneese visschers, ontrent en bij de strandt van 't eylandt Nera komende, om te visschen, sullen deselve niet vermogen int bosch te gaen, om klappes off anders te halen meer dañ zij tot nooddrufft om dan te drincken van doen hebben ende soo contrarie bevonden wordt, sall men haer prauwen opt strandt ende niet jut bosch halen ende soo eenige groote prauwen, vermits op droogh sittende, schade soude mogen lyden met clappus off anders vant t' eylandt Nera gehaelt quam te krygen ${ }^{\mathbf{5}}$, en zall men desellve niet op strandt haelen, maer voor ancker offte andersints vasst-

1 Slaman of Celammon.

${ }^{2}$ Vgl. contract X, 23 Mei 1602.

3 Dender.

4 Ourat??

${ }^{5}$ De zin is hier bedorven. Klappes of elappus = klappernoten. 
gemaeckt drifftigh laten tot naerder advys ende dispositie vandt fordt.

Ende bij aldien eenige Bandaneesen van bovengenoemde plaetsen genootsaeckt waren, naer Lonthor offte Ortatten te gaen offte varen. sullen gehouden wesen een witte vlagge offte vreeteycken op hare prauweu te setten. Ende te lande reysende deselve zijn in de handt opgereght gedragen, ende en zullen niet vermogen, 't zij te water offte te lande te reysen, meer wapenen by haer hebbende [dan] een parangh offte crys ijder persoon ende soo wie contrarie bevonden wordt te doen, zullen als vijandt aengehouden, aengehaellt ende getracteerdt worden.

De voornoemde Bandaneesen sullen gehouden zijn, als boven geseijt, goede foellie ende nooten brengen ende wie bevonden wordt, mannekens foelie ${ }^{1}$ onder de goede te brengen, zall voor d'eerste maele deselve well schoon ende claer garbuleren ende alsdan aen den Commies leveren ende [ten] tweede male bevonden zijnde, sall men all sulcke goedt datelijck verbranden.

Eenige Bandaneese prauwen, joncken offte ander vaertuijgh in zee onse Hollandsche schepen off fregatten gemoetende, sullen gehouden zijn, zoo wanneer men naer haer schiet, haer zeylen datelijck te strycken, opdat zij den anderen mogen komen te spreecken ende soo deselve goede paspoordt offte bescheydt hebben, sall men haer vrij ende ongemolesteerdt laten passeeren ende repasseren.

Aldus geaccordeerdt ende overeengekomen bij de orangcays ende oversten van Salemme jn den name van de bovengenoemde plaetsen ter eenre ende den Erntfeste Ed ${ }^{\text {en }}$ Lourens Reael, gouvern ${ }^{r}$ gener ${ }^{l}$ over d'Oostjndies, ter andere zijde, ter presentie van lebe Later Maynen ende Adres ${ }^{2}$ als tuijgen, mede borgers van Salamme, den $25^{\text {en }}$ July $^{3}$ 1618. In t'casteell Nassouw op't eijlandt Nera in Banda.

\section{ARABIË.}

\section{Juli 1618. 4}

De eerste aanrakingen der Nederlanders met Arabie vonden plaats in 1614, bij gelegenheid van de reis naar Indië van den GG. Gerard Reynst,

\footnotetext{
1 Blijkbaar foelie van mannetjes-noten.

${ }^{2}$ De spelling der namen is blijkbaar verknoeid. In den eersten is het woord „lebeh" (dorpsgeestelijke, schriftgeleerde) te herkennen.

\$ Vermoedelijk Juni, want 11 Juli 1618 was Reael reeds weder van Banda vertrokken.

4 Uit het Contractboek.
} 
begonnen in Juli 1613. De bekende Pieter van den Broecke maakte als opperkoopman deze reis mede en werd onderweg door Reynst naar de Roode Zee gezonden, om handelsbetrekkingen aan te knoopen. In Augustus 1614 kwam hij in Aden en vandaar ging hij o. a. naar Shihir ten Oosten van Aden, in Hadramaut. In 1615 werd Van den Broecke, die in December 1614 te Bantam aankwam, opnieuw naar Arabië gezonden. In Januari $1616 \mathrm{kwam}$ hij bij Shihir, en ging vandaar naar Mocha. Uit Mocha deed hij een reis naar Sana, ten N.O. van Mocha, naar den beglerbeg (opperstadhouder namens den sultan van Turkije) van den wilajet Yemen. Ofschoon hij overal uitstekend werd ontvangen, kon hij niet geraken tot blijvende factorijen: de inheemsche autoriteiten moesten daarvan blijkbaar niet veel hebben. Wel echter werd de handel toegestaan. De O. I. C. zag het belang er van in; de Staten-Generaal spanden zich er voor en het gevolg was onderstaande last van den sultan van Turkeije, Osman II, aan den beglerbeg van Yemen. (Vgl. het Ms. journaal van Pieter van den Broecke in de Universiteits-bibliotheek te Leiden). Ofschoon de Staten-Generaal, en niet de O. I. C., hier met Turkije hebben gehandeld, meen ik toch, het document hier te mogen opnemen.

Translaet van een commandement des Turschen keyser aen den beglerbeij, dat is viceroij van Jemen.

Sulltan Ossman ${ }^{1}$ Chan, zoon van sulltan Aghmat Chan, alltijt victorieus.

Ghij, die zijt een $\mathrm{H}^{\mathrm{r}}$ der $\mathrm{H}^{\text {ren }}$ ende een gener ${ }^{l}$ over andere gouver ${ }^{r s}$, vereerdt met grooth $^{t}$ en authoriteijt, verkoosen van Godt ende door onse gratie gemaeckt beglerbey, dat is viceroy van Jemen. Als dese onse hooge keyzerlycke signature daer zall komen, zult ghij weten, hoe dat den ambassad ${ }^{\mathrm{r}}$ van de Generale Staten van de Vereenighde Nederlanden, ${ }^{2}$ residerende aen onse keyserlycke porta, een requesste aen de selvige heefft gepresenteerdt, te kennen gevende, hoe dat voor desen, nae dat de hooghgedaghte Generale Staten haren ambassad ${ }^{r}$ aen onse keyserlycke porta gesonden ende met deselvige de vrientschap in opreghtigh ${ }^{t}$ ende sinceryteyt beslooten hadden, in de caputulatien, ${ }^{3}$. die haer luyden gegeven zijn geweest, gescreven is dat de coopluyden, haere ondersaten ende jnwoonders van alle de landen onder haer gebiedt sorteerende, mogen komen gaen ende negotieren in alle de landen van onse bewaerde (?) rycken, zonder van ymandt daerinne belet offte gemolesteert te mogen werden, ende allsoo de hooggedaghte Generale Staten van de

1 Osman II, zoon van Achmed I, was sultan van Turkije van 1618-1622.

${ }^{2}$ Cornelis Haga. Vgl. Blok, Nederlandsche volk, IV, bldz. 21, 70, 363.

3 Verdragen met Turkije. 
Vereenighde Nederlanden in de Orientaellsche Jndien eenige eylanden ende starkten bezitten ende de Nederlandsche coopluydens in de selvige woonen ende negotieren, komende ende gaende in alle de schalen ${ }^{1}$ ende havenen van de voorgenoemde Jndien, soo ist dat den ambassad ${ }^{\mathrm{r}}$ van de Nederlanden resideerende aen onze keyserlycke porta in de naem van de Generale Staten, zyne meesters, versoght heefft, dat de coopluyden, woonende in de Jndien, sorterende onder hare gehoorsaemh ${ }^{t}$, gelijck de goede vrundschap toebetaemt ende in conformiteijt van onse keyserlycke caputalen ${ }^{2}$, met hare schepen uyt de selvige Jndien mogen komen ende gaen in Mucha, Aden, Schehery ende andere scalen dependerende van Jemen $^{3}$ ende in deselvige vreedsamelijck handelen ende haere coopluydens ende consuls woonen, zonder van ymandt belet offte gemolesteerdt te worden, versoekende tot dien fijne onse keyserlycke commandementen, weshalven allsoo de hooghgedaghte Generale Staten voor desen haren ambassad ${ }^{\mathrm{r}}$ aen onse keysersycke porta gesonden ende de vrundschap met een goede ende opreghte meninge volbraght hebben, soo is ook hare begeerte gevallen ter plaetse daer aen genomen is, ${ }^{4}$ ende onse hooge $\mathrm{Key}^{\mathrm{rs}}$ bevell is uytgegaen op dese manier, dat zyluydens met hare schepen vreedsamelijck mogen konnen gaen ende negotieren, hare consuls ende coopluydens woonende in alle de voorgenoemde plaetsen van Mocha, Aden, Schehery ende alle andere scalen, dependerende van Jemen, zonder dat ymandt jegens de keyserlijcke kapitulatien haer magh hinderen offte molesteren. Wij commanderen derhalven, dat dese keyserlycke beveelen daer komende de Nederlandsche coopluydens, soo lange als van hare zijde niet en zall gedaen worden contrarierende de vrundschap, met hare schepen zullen mogen negotieren, haere consuls en coopluydens wonende in de voorgenoemde plaetsen, dependerende van Jemen ende dat niemandt jegens de keyserlijcke caputilatie ende heylige wet haer daerinne mag verhinderen offte molesteren, t'welck onse ernstige keyserlijcke- wille is, overmits het vertrouwen dat wij hebben, dat de hooghgedaghte Generale Staten volcomentlijck ende opreghtelijck in de vrienschap sullen volharden ende vast blijven staen. Jn dese maniere ende in conformiteyt van onse keyserlijcke bevelen sullen zoo wie [wel?] hare consulls als koopluyden in de voorgenoemde

1 Havens, stapelplaatsen (Fransch: échelle).

2 Capitulatiën.

3 Vgl. het Ms. journaal van Pieter van den Broecke.

4 De zin is hier bedorven. 
plaetsen mogen woonen ende in alle hare andere affayren, nae dat van noode zall wesen, zult ghij haer eere ende vrindtschap bewijsen, opdat zij in stillte ende vreede mogen blijven. Alldus zullt ghij weten ende dese onze keyserlijcke bevelen gelesen hebbende, deselvige restitueeren in handen van de consulls ende coopluydens ende sullt aen dese onze hooge keyserlijcke signature gelooff geven. Geschreven in Constantinopelen int beginsell van den maendt Rezieb $1027,{ }^{1}$ twelck is nae onse rekeninge int beginsell van Julio 1618.

Onder aen in dorse is de signatuijre van den Secretaris van State ende beteijckent is gesien.

\section{SOLOR- EN TIMOR-GROEP.}

7 September 1618. ${ }^{2}$

Toen Apollonius Scotte in April 1613 het Portugeesche fort op Solor had veroverd, sloot hij een contract met sommige hoofden van dit en eenige omliggende eilanden. (Vgl. Tiele, Europeërs, VIII, bldz. 137-139.) Van dit contract is mij geen exemplaar onder oogen gekomen, wel onderstaande copie van zijn hernieuwing en bevestiging ${ }^{3}$ in 1618 door Jan Pieterszoon Coen. In 1615 hadden wij ons fort op Solor geslecht, omdat de GG. Reynst van meening was, dat het niet noodig was voor onzen handel op Timor. (Tiele, t. a. p., VUI, bldz. 202-204). Maar in 1618 werd het hersteld op verzoek onzer Soloreesche bondgenooten, die den oorlog tegen de Portugeezen hadden volgehouden en omdat de handel op Timor voordeelen gaf voldoende om er toe over te gaan. Soloreesche gezanten waren te Djakatra verschenen, om het verzoek te doen en bij die gelegenheid werd het contract van 1613 hernieuwd. (Vgl. Tiele, t. a. p., IX, bldz. 237, v.; onuitgegeven missives van Coen aan de Bewindhebbers, 22 Augustus 1617, 24 Juni 1618; onuitgegeven resoluties van President en Raad te Djakatra, 30 Juni en 13 Augustus 1618, enz.)

Contract gemaeckt met den aely chilly Patany ${ }^{4}$ ende $d^{\prime} E^{e}$ van Sooloor.

Eerstelijck ick, capiteijn Appollonius Schotte, vassall ende dienaer

1 Rĕdjab?

2 Uit het Contractboek.

3 Dat Tiele, t. a. p., bldz. 139, noot 3 , zegt, dat het contract "met de verkeerde dagteekening 7 Sept. 1618" wordt gevonden in het Contractboek, is dus minder nauwkeurig uitgedrukt.

4 Wie die kaitjil Partani (Bartani, Patani) is geweest? Tiele, t. a.p., bldz. 138, zegt in noot ', dat hij "misschien een Ternataan van afkomst" was. In het exemplaar zijner opstellen, dat hij zelf gebruikte en dat thans in mijn bezit is, heeft hij een manuscripte aanteekening gemaakt bij deze 
van den prince Maurits, van de steeden Hollandt ende Zeelandt, contracteren met chilly Partany ende de sangadgis, namentlijck sangadge Lamahale ${ }^{1}$, sengadije Adonnare ${ }^{1}$, ende Servetty ${ }^{2}$, als sangadge Lammakere ${ }^{3}$ ende sangadge Trong ${ }^{1}$ in de veroveringh van de plaetse ende tcassteell Sooloor, hebben op dussdanige maniere met den anderen gecontracteerdt: soo ymandt bestaedt, overlasst te doen aen chillij Partanij ofte de sengadgis voornoemt, dat het zall in sulcken consequentie getrocken worden offt geschiede aan den koninck van Ternate ${ }^{4}$ offte aen den koninck van Hollandt. Wij sullen, des van noode wesende, revengeren ende voorkomen.

Ten anderen zoo ymandt bestondt eenigh leedt, onreght offte overlasst aen de Hollanders te doen, zullen die van Soloor ende die van de Moluccos ${ }^{4}$ gehouden zijn, met hunne maght voor te komen, gelijck mede den Hollanders aen die van Solor gehouden sullen zijn te doen en tegens hunne vijanden te beschermen.

Item soo die van Soloor eenige mishandelinge deden aen de Hollanders, die zullen van ons gesamentlijck gestrafft worden ende ingevalle de Hollanders die van Soloor onderstonden te beschadigen offte onheyll aen te doen, sullen mede op dezelffde maniere door den Raedt gestrafft te worden. Wyders heeft den Capiteijn Moor 5 gecontracteerdt met chellij Patanij ende $d^{\prime} E d^{e}$ van 't landt van Soloor, mits hun vereerende vijff bassen ${ }^{6}$, te weten yder plaetse een basse als mede yder plaetse een corgie $^{7}$ kleeden, hun voorders belastende, zoo ymandt quame te bestaen vyandschap aen chillij Partanij offte aen d'Ed. van Soloor te doen, datse in sulcken gevalle 't selve aen $d^{\prime} E d^{\text {en }} \mathrm{H}^{\mathrm{r}}$ Gener' zouden adviseren ende dat de

bladzijde en daarin spreekt hij bepaald van „de Ternataansche Kaitsjil Partani." (Vgl. Tiele, Bouwstoffen, I, bldz. 84, 94.) Verschillende streken van Solor en omliggende eilanden "staen van outs onder den Coninck van Ternaten, maer werden geregeert van hare Sangagys, die egeen gebiet en hebben, maer nyet anders als hoofden van de gemeenten en zyn, ende alsoo niet en vermogen als tgene die gemeynte belieft." Kaitjil Partani bekleedde op Solor een aanzienlijke plaats.

${ }^{1}$ Op Andonare (Adoenara).

${ }^{2}$ Serbette op Flores.

3 Op Solor.

4 Dit wijst weder op den band tusschen Ternate en deze streken.

${ }^{5}$ Hier zal met dezen titel genoemd zijn A. Scotte.

- Scheepsgeschut.

7 Volgens Hobson-Jobson, p. 197, is dit een handelsterm voor "a score" (een twintigtal). 
coopluyden van de scheepen alsdan die van Solor zouden komen assisteeren tegen hunne vyanden, min off meer offtet landt van Sooloor de koninck Moulasser ${ }^{1}$ van Ternaten toebehoorende; dat oock de Capiteijn Moor aen den koninck van Goa offte Macassar ${ }^{2}$ zoude adviseren, dat hij hem niet en soude onderstaen ende ververderen die van Soloor te beschadigen offte vyandschap aen te doen offte dattet den Capiteijn Moor van wegen die van Soloor soude wreeken ende sulx beletten. ${ }^{3}$

Vorders dat de Hollanders die van Solor geen overlast en soude aendoen, als mede dat men die van Solor by hun geloove offte seckte ${ }^{+}$zoude laten blyven, zonder int minste haer tot ander geloove te persuaderen, min nogh meer, gelyck men aen den koninck van Ternate doet; ende zoo ymandt hier tegen quame te woelen, soude gestrafft worden als een overtreder van gebodt van den koninck van. Hollandt. Soo die van Soloor daer en tegen hun verloopen tegen de Hollanders, sullen door chilly Pattany ende d' Ede van Solor gestrafft worden.

Offte het geviell, tot Soloor eenige van Ternata quam, t'zij met brieven offte zonder deselve, sullen geexamineert ende gevisiteerdt worden door den Capiteyn als door chilly Partany ende d'Ed ${ }^{\text {le }}$ van 't landt van Soloor, offte het brieven van gelooff ${ }^{5}$ offte niet, en soo bevonden worde, dat ymandt onderstonde vallsche brieven uijt den name van den $k^{k}{ }^{k}$ van Ternate hier te brengen, die niet behoorlijck gemerckt offte gezegelt en waren, desulcke in eenige faute bevonden werden, zullen nae merite van zaecken door den Raedt gestrafft worden.

Nogh heefft den $\mathrm{Cap}^{\mathrm{n}}$ Moor gecontracteerdt, hoe men het cooper als sillvergelt soude goedt van alloy maeken, zijn behoorlycke gewighte laten hebben, als mede op zynen besetten prijs stellen, op datter niemandt door .verkordt en soude werden, als ook mere eenen zekeren prijs te stellen op de visch, op den touwack ${ }^{6}$ ende arack, ende zoo ymandt op de marckt quame te kyven offte questie te

\footnotetext{
1 Sultan Modafar.

2 Gowa, hier $=$ Makassar.

3 Het is bekend, dat de Makassaren reeds op verschillende plaatsen dezer eilanden hun gezag hadden gevestigd. (Vgl. Tiele, Europeërs, VIII, bldz. 136).

4 Een gedeelte der Soloreezen was door de Portugeezen tot het Christendom bekeerd. (Vgl. bv. Tiele, t. a. p., VIII, bldz. 202.)

${ }^{5}$ Credentiebrieven, geloofsbrieven.

- Toewak, een bedwelmende drank.
} 
moveren, zullen door den Koopman ${ }^{1}$ daer over gestrafft worden, allsoo sulcke kraakelen maer ontstaen door koopen ende verkoopen.

Wijders zoo eenige schepen quamen ende vervielen op 't landt van d'Eijnde ${ }^{2}$ offte Casike, ${ }^{3}$ Pagga ${ }^{4}$ als mede op de andere kant van landt aen Tanijongh van Goa ${ }^{5}$ ende de Hollanders alldaer een ongeluck offte resolster ${ }^{6}$ overquamen, zullen die van Sooloor gehouden zijn, deselve in alle manieren te helpen ende te assisteren.

Eenige vrouwen lyber ende vrye wesende, doghter offte weduwe, hun begeerden met de Holland ${ }^{r s}$ in de huwelycken staet te begeven, sallt toegelaten worden ${ }^{7}$; soo ymandts vrouwen offte kinderen hun quamen te verloopen, sullen door den $\mathrm{Cap}^{\mathrm{n}}$ ende Chilly gestrafft worden.

Item soo eenige Moorse natie ${ }^{8}$ bij de Hollanders quamen wegh te loopen, zullen de Hollanders deselve wederom restitueren; van gelycken zoo der eenige Christene quamen bij de Mooren te loopen, sullen de Mooren gehouden zijn, deselve wederom te reghte te brengen aen den toebehoorenden.

Chilly Partany ende alle $\mathrm{d}^{\prime} \mathrm{Ed}^{\mathrm{le}}$ van $\mathrm{t}$ landt van Soloor, jegenwoordigh wesende, besluyten met $\mathrm{S}^{\mathrm{r}} \mathrm{Cap}^{\mathrm{n}}$ Moor, offte ${ }^{9}$ nae deesen eenige plaetsen meer quamen ende contribueerden aen de Hollanders ende het geviele, dat ze die van Soloor bedurven, hun landt schade aen deede offte eenige Hollanders doodt smeeten, sullen ons daer buyten houden. ${ }^{10}$

Ten andren zoo de Hollan ${ }^{\text {rs }}$ met die van Banda quamen met den anderen vreede te treffen ende die van Banda hun beteren willden,

1 De vertegenwoordiger der O. I. C.

2 Endeh.

s Sikka?

4 Paga.

5 In 't Aardrïkskundig en Statistiek Woordenboek van Nederlandsch Indië wordt genoemd "Goa, eiland bij Flores, welks middenpunt ligt op 9o $5^{\prime} \mathrm{Z}$. Br., 1210 53' O. L." Maar de door mij gebruikte kopie is onduidelijk. Er kan ook gelezen worden: "Tanijongh vongoa", misschien bongoa of boenga. Tandjong boenga $=$ bloemenkaap $=$ Cabo de flores $($ Portugeeseh), de Noordoostelijke spits van Flores, heeft vermoedelijk den naam aan het eiland gegeven.

6 Desaster?

7 Vele Portugeezen waren gehuwd met Soloreesche vrouwen.

8 De Mohammedaansche propaganda werd van Makassar uit in deze streken gedreven. (Vgl. Tiele, Europeërs, VII, bldz. 136.)

9 Indien.

10 Geheel duidelijk is mij hier de bedoeling niet, evenmin die als van de volgende alinea. 
dogh so die van Banda niet en verstaen tot pays, sullen de Hollanders hun getroost wezen etc ${ }^{\mathrm{a}}$.

Was onderteekendt Appolonius Schotte, Willem Jacobszoon, Jan Janszoon, Fr. van de Velde, 1 Creijn v. Raemburg, Gregorius Cornelij.

Nogh stondt onder dese namen geschreven:

Den jnhoudt van voorschreven contract ons overtolckt ${ }^{2}$ wesende ende verstaen hebbende, annoveren, renoveren ende confirmeren wij $t^{\prime}$ allige in allen deele mits desen. Jn Jacatra ady $7^{\mathrm{e}} 7^{\text {ber }} \mathrm{A}^{\circ} 1618$. Was onderteeckend Jan Pieterszoon Coen.

\section{AMBON.}

\section{9, 20 November en 23 December 1618. ${ }^{3}$}

De gouverneur van Ambon, Blocq, werd in Juli 1617 als zoodanig vervangen door Van der Haghen, die daar bij den inlander „zeer wel gezien en bemind" was. Hij werd echter in 1618 lid van den Raad van Indië en Herman van Speult volgde hem in de Ambon-kwartieren op. Met kracht handhaafde deze het gezag der Compagnie. Zóó trad hij op tegen den zeeroof en den menschenhandel van sommige dorpen op KleinCeram, Cerams Noordkust, Boano, Kelang enz. en tuchtigde verschillende kampongs, wier bewoners dan ook het hoofd in den schoot legden. (Tịele, Europeërs, IX, bldz. 202-206).

Aangezien de menigvuldige klagten over de overgroote rooveryen van die van Bonoa, geaccompagneert met die van Assahoedi, + Hatepoeteh ${ }^{5}$ ende Kelang, nog dagelyks augmenteren, zoo van onze onderdaanen, als van ouze geassocieerden, waar over genoodzaakt zyn onze macht te verzamelen, ende dat te meer, overmits Kimelaha Sabadyn, ${ }^{6}$ Stadhouder wegens den Koning van Ternate, onder wiens protectie, en bescherming, die van Bonoa, Assahoedi, Hatepoeteh, en Kelang staan, over verscheide onze aanklagten ons geen recht

1 Vermoedelijk Adriaan van de Velde, die Scotte's opvolger werd. (Tiele, Bouwstoffen, I, bldz. X.)

2 Ook dit contract bv. was dus niet in het Nederlandsch opgemaakt.

3 Overgenomen uit Valentijn, Ambon, II, b, bldz. 41, v.

4 Op de Westkust van Klein-Ceram.

${ }^{5}$ Hatapoetih op Kelang?

6 Opvolger van Bassi Frangi als stadhouder van Klein-Ceram: (Zie hiervóór bldz. 71 en Tiele, t. a. p., bldz. 264). 
en heeft gedaan, allegerende tot zyn excuse, 't zelve niet magtig te wezen, onaangezien hy onlangs geleden tot twee verscheide reizen daar is geweest met 5 of 6 correcorren, welke excusen niet suffiçant waren om langer zoodanigen geweld, en overlast te lyden, te meer, considererende, dat niet alleen kimelaha Sabadyn naarlatig was gebleven omme ons genoeg te doen over den overlast, ons by die van Boano, ende consoorten aangedaan, dan dat mede over verscheide insolente proceduren der Loehoenesen ${ }^{1}$ daar klagtig over zijn geweest, geen regt en was gevolgt, het welke alles naar deliberatie overwogen zynde, zoo is eenstemmig bij den Luitenant-Gouverueur ${ }^{2}$ voorsz., onze onderdanen en geassocieerden besloten, dat wy met onze armade, bestaande in 35 corcorren, zouden onderstaan, of men die van Boano, en hare consoorten, zoude konnen constringeeren met geweld, tot voldoeninge van onze geleden schaden, waar op is gevolgd, dat wy den 5 November met de gantsche armade onze reize hebben vervorderd, ende eigentlyk den 14 November voor Boana gearriveerd, alwaar besloten wierd 't geene volgd:

Op huiden den 19 November 1618 zijn op strand van Boano vergadert, Herman van Speult, Lieutenant Gouverneur en Directeur over de Eilanden, Fortressen ende commercien van Amboina, met meest alle de Koningen en Oversten van de landen en steden, onder het bovengemelde Gouvernement resorteerende, nevens onze geassocieerden, als Capitein Hitoe, den Koning van Hitoe, en de Orang Kaja's van Thamahoe en Nollot ${ }^{3}$ mitsgaders Lato Coli ${ }^{4}$, ende Kipati Naro ${ }^{5}$, als middelaars ten eenre, ende den Sengadji ${ }^{6}$ van

\footnotetext{
1 De stadhouder van Klein-Ceram resideerde toen te Loehoe. (Bouwstoffen, I, bldz. III).

2 Van Speult nam toen nog slechts het gouverneurschap waar en had den titel behouden, dien hij reeds onder Van der Haghen had gehad. (Tiele, Europeërs, VIII, bldz. 198).

3 Beide op Saparoea.

4 Latoe = koning (G. W. W. C. Van Hoëvell in deze Bijdragen, IV reeks, I, bldz. 78) Dus de „koning" van Koli (In 't Noorden van Ceram of op Kelang)?

5 De kiaih pati van Naro?

- De vertegenwoordiger van Ternate's sultan op het eiland.
} 
Boano ten andere zijde, de welke naar verscheide sessies in genade is aangenomen op naarvolgende conditien.

Eerstelijk is by den Luitenant Gouverneur voorsz. met hulpe van de bovengemelde Heeren ter neder gelegd, doot en te niete gedaan, met desistentie van alle vorige pretensien, zoo 't geene zedert de tyden van de Portugeesen op die van Boano hadden te pretenderen over zodanige rooveryen, van luiden ende goederen, als by die van Boano voorsz. zijn gecommitteerd, wel verstaande, dat die van Boano eerst ende vooral zullen restitueeren; alle zoodanige gevangenen, als zy 't zeedert de tyden van de Portugeezen genomen hebben, welke verklaringe zy luiden zullen gehouden wezen te doen op haren Moshhâf, ende zal de restitutie geschieden in volgende manieren, te weten, dat zij de geene, die nog in leven ende in hare handen zijn, persoonlyk wederom zullen geven ende de geene, die overleden ofte buitens lands verkogt zyn, zullen zy vergoeden, voor een Orang Kaja 100 petolen, ende voor een slave 60 petolen, ende tot eene amende van hare begane faute beloven zy te betalen aan den Luitenant Gouverneur voorsz. 1800 petolen, ende daar en boven eene corcor van vier gnadjos. ${ }^{1}$

Mede beloofden die van Boano voorsz. van nu voortaan nog tot geenigen dage meer te rooven op eenige der voorsz. Heeren landen, luiden, ofte goederen, ende haar voorder te dragen, als goede en getrouwe geassocieerden toestaat.

Doch gemerkt by de voorsz. Heeren voor zeker gehouden werd, dat (naar 't gemein spreekwoord) de exter haar huppelen niet en zal agterwegen blyven (als wezende zy luiden van over ettelyke 100 jaaren gewoon, hun met rooven te erneeren) ${ }^{2}$ waar over te bedugten staat, zy haar eerlang wederom zullen te buiten gaan, in welken gevallen de bovengemelde Heeren, onze onderdanen, ende geassocieerden, gezamenderhand beloven, ende zweeren, aan den Luitenant Gouverneur voorsz. op de eerste aanklagte hem te assisteeren met alle hare magt, omme die van Boano ofte de contraventeurs van dezen geheel te destrueeren ende uit te roeien. Aldus gedaan, en besloten op de strand van Boano. Datum ut supra.

Op huiden den 20 November 1618 zoo zyn ten beroepe van den

I Roeibanken. (Valentijn, Ambon, a, bldz. 183. Zie ook Van Hoëvell, Ambonsch-Maleisch, bldz. 23, sub voce "ngadjoe" en De Clereq, Maleisch der Molukken, bldz. 39.

2 Onderhouden. 
Luitenant Gouverneur, nevens onze onderdanen en geassocieerden voorsz. ter eenre, gecompareerd op de strand van Saoedi 1 de orangkaja's der zelver negry, mitsgaders Latoe Coli, en kipati Naro, als middelaars, de welke, als complicen van die vau Boano in de rooving, hebben gerestitueerd alle het volk, dat zij voor haar quote ${ }^{2}$ hadden gekregen, te weten 7 perzoonen; betalende daarenboven eene amende, ofte boete van drie honderd petoolen, nevens een coracorre van vier gnadjo's, hebbende haar daarbenevens onderworpen de bovengemelde conditien, die zy lieden op haren Moshhâf hebben bezworen. Aldus gedaan ter bovengemelde plaatse. Datum ut supra.

Op huiden den 23n December 1618 compareerden ten beroepe van de bovengemelde heeren in de $\operatorname{logie}^{3}$ van Cambello de orang kaja's van Hatepoeteh en Kelang, die welke mede schuldig in de rooving met die van Boano zijn bevonden, de welke restitueerden een persoon ofte gevangen, zoo zij voor hunlieden quote hadden genoten, betalende daarenboven voor een boete ofte amende drie honderd petolen; haar submitterende zoodanige articulen, als met die van Boano waren beraamd, hebbende 't zelve bevestigt op haren Moshhâf.

Aldus gedaan ter bovengemelde plaatze. Datum ut supra.

\section{DJA KATRA.}

\section{Januari 1619. 4}

De gebeurtenissen in Djakatra op, het eind van 1618 en het begin van 1619 zijn bekend. De strijd om het monopolie, tusschen de Nederlanders en de Engelschen in het Oosten van den Archipel, vooral op de Bandagroep, tot uitbarsting gekomen, zette zich aan Java's stranden voort, o. a. in Bantam en Djakatra, in welke beide plaatsen deze Westersche kooplieden óók tegen elkander concurreerden, maar geen van beide gezien waren. Slechts de hoop op handel of andere voordeelen deed hare bebestuurders nu eens de eene, dan weder de andere vreemdelingen vriendelijker behandelen.

\section{Assahoedi.}

2 Aandeel.

${ }^{3}$ Sedert 1615 hadden wij daar een garnizoentje. (Vgl. Tiele, Europeërs, VIII, bldz. 145-149, en wat geheel onze verhoudingen op Klein-Ceram betreft, zie Bouwstoffen, I, passim, Register: sub voce Kambeloe, Loehoe, enz.)

4 Uit het Contractboek. - Van der Chijs, Jakatra, bldz. 210, heeft dit contract afgedrukt „volgens een oud afschrift op de Alg. Secretarie te Batavia berustende." 
Op last van Coen hadden de onzen hunne loge te Djakatra versterkt. en met een garnizoentje vuorzien. Bemerkende, dat zijne positie daar niet veilig was, besloot hij den 22 October 1618, "met de versterking. der loge voort te varen en haar tegen alle geweld in volkomen defensie te brengen." Dit verbitterde Djakatra, dat - natuurlijk - niet wilde weten van een Nederlandsche sterkte in zijn stad - en het helde weder meer tot de Engelschen over. Thomas Dale, toen de leider der Engelsche politiek aan Java's kusten, wilde zich over de houding der Nederlanders op de Bandagroep tegen de Engelschen wreken en nam een Nederlandsch schip bij Bantam. Ook hier op Java dus openlijke vijandschap tusschen de beide Westersche natiën. Coen trad vijandig tegen de Engelschen in Djakatra op; verliet 30 December deze vestiging; raakte 2 Januari 1619 slaags met de Engelsehe vloot en ging daarop naar het Oosten van den Archipel. Hij had de verdediging der Nederlandsche sterkte overgelaten aan Pieter van den Broecke. Zij werd belegerd door Engelschen en Djakatranen. Van den Broecke ging in op het denkbeeld van Djakrata om te onderhandelen en onderstaand contract werd gesloten. (Vgl. Tiele; Europëers, IX, bldz. 207-217; Van der Chijs, Jakatra, bldz. 66-89; De Jonge, Opkomst, IV, bldz. XLVII-LVI, LXXIX-XCVII; Van Deventer, Nederlanders op Java, I, bldz. 109.)

Nieuw accoordt ende bestandt, gemaeckt met den koninck van Jacatra, genaemt Wydyaeck Ramma ${ }^{1}$, ter eenre ende Pieter van den Broeke, command ${ }^{\mathrm{r}}$, ter andere zijde, wegens de voorgaende oorlogh tusschen hem ende de Generale Vereenigde Oostjndische Comp ${ }^{\mathrm{e}}$ geresen, in ordre als volght.

Eerstelijck zall den koninck voorschreven beloove, het voorgaende contract, bij de Gener ${ }^{\prime}$ Pieter Both ende Gerrit Reynst geteekent $^{2}$, in alles te onderhouden ende naer te komen als van [vóór?] desen geschiet is.

Ten tweede zal den Koninck gehouden wesen te gedoogen, dat ons fordt, welck hij seght tegens de voorgaende contracten getimmert te zijn, in effect als nu tegenwoordigh is zall blijven staen ter [terug?] komste van den $\mathrm{H}^{\mathrm{r}}$ Gener $^{13}$, zonder in die tijt daeraen ijets meer te timmeren.

Ten derde niet toestaen, dat d'Engelsche huijsinge offte logie soo naer ons fort sullen bouwen als voor desen geweest is, om alle ongeneughte voor te komen.

1 Widjảjå Kråmå.

2 Zie hiervóór, $\mathrm{n}^{\mathrm{i}} \mathrm{XXXVIII}$ en XLIX.

3 Gouverneur-Generaal, nl. Jan Pieterszoon Coen. Deze, in 1617 door de Bewindhebbers tot gouverneur-generaal benoemd, had nog wel niet deze hooge waardigheid aanvaard, maar wordt, ook door Van den Broecke in zijn manuscript journaal, reeds "generael" genoemd. 
Ten vierde datter op twintigh vadem buijten ons pagger geen huijsen van Chinesen offte Javanen mogen gebout worden.

$\mathrm{Om}$ welcke voorverhaellde poincten als 't geene den $\mathrm{Ko}_{\mathrm{o}^{\mathrm{k}}}$ vorder pretendeert, men hem betalen zall eens voor all de somme van ses duijsend $R^{\text {en }}$ van aghten, te weten 5000 in comptant en 1000 in kleeden, waermede hij beloofft, alle voorgaende questies doodt ende ter needer geleijt sullen zijn.

Alle welcke bovengeschreven artijkelen wij ondergeschreven bekeunen met malcanderen gecontracteerdt te hebben ende belooven van weder zijde nu ende ten allen tijde onverbrekelijck te onderhouden. Jn kennisse der waerh ${ }^{t}$ hebben dit met ons gewoonlijcke handteken ondertekent. Int fordt Jaccatra den $19^{\text {en }} \mathrm{Ja}^{\text {ry }} 1619$. Onderstonden eenige Javaense letteren geschreven ${ }^{1}$.

\section{DJAKA'TRA.}

\section{Februari 1619. 2}

Van den Broecke legde in zijne positie te Djakatra geen voldoend doorzicht aan den dag; hij liep in de val en werd met enkele Nederlanders den 22 Januari op verraderlijke wijze gevangen genomen. Pieter van Raey kreeg nu de leiding. Deze, van meening, dat de versterking niet lang zoude kunnen uitbouden eene belegering van de thans nauw verbonden Djakatranen en Engelschen, sloot den 31 Januari onderstaand verdrag van overgave met Dale en den pangeran van Djakatra, welk verdrag den volgenden dag werd bekrachtigd. (Vgl. Van der Chijs, Jakatra, bldz. 90-103; De Jonge, Opkomst, IV, bldz. XCVII-CVII; Tiele, Europeërs, IX, bldz. 217-218; Van Deventer, Nederlanders op Java, I, bldz. 110 , v. v.; ms. journaal van Van den Broecke, op deze data).

1 Van den Broecke vertelt in zijn ms. journaal het volgende:

„Den $19^{\text {en }}$ ditto (Januari) is ons volek op het versoeck van de Jauannen weder naer thoff gegaen met het contrackt omdat het den Conninck soude onderteijckennen, bij soo verde hem de conditien aenstonden; dan den Conninck is niet te voorsijn gecommen, soo dat sonder jets berecht [te] hebben, wederom quamen.

Den 20 ditto is ons volck door queaj Aria wederom geroepen ten hove te commen. Daer commende was den Conninck, geaccompanieert met syn twee broeders, den prister ende den tommagom neffens noch eenigh ander groote heeren, als men wel dencken can dat op Java sijn, den Conninck, naer langh versijden reeden over en weder gealligeert sijnde, accorderden de punten vant contrackt seer noode, naer dat het hem differente malen van punt tot punt vijet onsse Duijtsse taele getolckt was; versochten, sijn handttijcken daer op dede, het welck eijndelijek ondertijekent heeft."

2 Uit het Contractboek. - Van der Chijs heeft gepubliceerd een, oud afschrift op de Alg. Secretarie te Batavia berustende." (t. a. p., bldz. 212.) 
Artijkelen geaccord $^{t}$ tusschen den coninck van Jacatra, den $\mathrm{Ed}^{\mathrm{en}} \mathrm{H}^{\mathrm{r}}$ gener ${ }^{\mathrm{l}}$ president, raedt ende coopl $^{\mathrm{n}}$ van de Engellsche Comp ${ }^{e}$, trafyquerende jnde Oostjndien ter eender zijde ende den command ${ }^{\mathrm{r}}$ capiteyn ende coopluijden vande Nederlandsche Vereenighde Oostjndische Comp ${ }^{\mathrm{e}}$ jnt fordt Jacatra ter andere zijde, den $1^{\mathrm{e}}$ Februarij $A^{\circ} 1619$.

Ten eersten sullen den command ${ }^{\mathrm{r}}$ cap $^{\mathrm{n}}$ ende coopl $^{\mathrm{n}}$ van de Nederlandsche Vereenigde Oostjndische Compe het fordt, volck, ammonitie van oorlooge aen de voornoemde Engelsche overgeven ende het gelt, de coopmanschappen, juwelen ende andere Comp ${ }^{\mathrm{s}}$ goederen aen den koninck van Jacatra.

Dies sullen de voornoemde Engelse weder aen de Hollanders geven een schip, daer voor van de comptanten, jegenwoordigh int fordt zynde, zall betaelt worden $2000 \mathrm{R}^{\mathrm{a}}$ van aghten. Het voorschreven schip zall versorght zijn met vier goede stucken, vyftigh musquets ende haer toebehooren, ses vaten kruijdt ende vyff en twintigh pieken, oock met goede zeylen, ankers, cabells ende victualie voor ses maenden tijts met vrijgeley van lyff ende liberteijt om te gaen naer de Cust van Cormandell offte daer het hem zall gelieven, uytgenomen Amboyna offte de Muluccos.

Sullen ook mede alle de Christenen int fordt zijnde liber ende vrij zijn, van wat natie offte qualiteyt zij oock moghten wesen, ende sullen mogen met hun uytdragen alle 't geene haer partjculierlijck toecomt, stoffen, kleederen ende jn comptanten de somma van $6200 \mathrm{R}^{\mathrm{a}}$ van aghten.' Daer eu boven en sullen hare persoonen ende goederen transporteeren bij d'Engelsche aen d'Eylanden ', sonder van de Javanen offte ymandt anders beschadigt te worden.

De Hollanders sullen gehouden wesen, eenen dagh naerde onderteekeningh van desen uyt het fordt te vertreckeu ende de geene die nogh ongedoopt zyn, sullen blyven binnen het fordt, uijtgesondert de Japonnesen ${ }^{2}$.

Ende die maghtigh zijn 't geweer te voeren, nu int fordt zijnde, ende ook de gevangenen sullen belooven, van nu aff tot toecomende November 1619 geene wapenen tegen d'Engellsche natie te voeren ende zullen derhallven ontlasst worden ende vrijgestellt worden als d'andere, alle hetwelcke wij tot allen tijde met eede bevesstigen.

' Journaal van Van den Broecke heeft: "de eijlanden voor Jacea."

2 Die in dienst waren van de Nederlanders. - Dat de Nederlanders niet naar Ambon of de Molukken mochten vertrekken, ligt natuurlijk hieraan, dat dáár toen hunne hoofdmacht was gevestigd. 
Soolange de Hollanders ende hare goederen aen de Eylanden sullen zijn, aldaer door twee schepen beschermt worden tegen alle Javaense ende andere vyanden meer.

Ende als het schip, daervan voorseyt is, zall gereet zyn, 't welck binnen thien offte vyffthien dagen geschieden zall, zullen deselve vertrecken ende ontfangen van de $\mathrm{Ed}^{\mathrm{en}} \mathrm{H}^{\mathrm{r}}$ generaell $\mathrm{S}^{\mathrm{r}}$ Thomas van Dale, Ridder ende gener ${ }^{l}$ van de Engellsche, vrij paspoordt om te gaen naer de voornoemde Custe van Cormandell ende zullen te zee ende te lande vrij zijn van alle molesstatie ende overlast van de Engelse voornoemt.

Van de Hollanders zullen gaen in osstagie aen de Engelse schepen twaelff personen, totdat het fordt in handen van den voornoemden gener ${ }^{l}$ ende d'Engelse zall overgeleverdt en dit contract aen beijde zyde volldaen zijn.

Oock en zullen geen Javanen, zoo lange de Hollanders nog int fordt zijn, mogen daerbinnen komen, dan alleen de geene die van den Koninck werden gesonden en dat niet boven de aght personen.

Welcke artykelen wij accordeeren ende belooven waerachtelijck naer te komen. Soo waerlijck hellpe ons Godt. Actum als boven jnt fordt Jacatra ${ }^{1}$.

\section{BANTAM.}

9 Februari 1619. 2

Zooals bekend is, is het verdrag van overgave van 31 Januari-1 Februari niet tot uitvoering gekomen en wel tengevolge van het optreden van Bantam. De inlandsche autoriteiten dáár hadden reeds met leede oogen gezien, dat de Nederlanders zich in Djakatra hadden versterkt, maar zagen evenmin gaarne, dat de Engelschen de Nederlandsche versterking zouden gaan bezetten. Geen machtsuitbreiding van welke deze beide Europeesche natiën ook! Bantam trad nu op in de zaken van Djakatra, hetwelk als een leen van Bantam werd aangemerkt. Een aanzienlijke Bantamsche macht kwam voor Djakatra, vóórdat de overgave feitelijk had plaats gevonden. Van de overgave kwam niets. Wel werden onderhandelingen begonnen tusschen de onzen en Bantam. Onderstaande voorwaarden werden ter eventueele bekrachtiging naar Bantam gezonden. (Vgl. Van der Chijs, Jakatra, bldz. 103-114; De Jonge, Opkomst, IV, bldz. CVII-CX; Tiele, Europeërs, bldz. 219-220; Van Deventer, Nederlanders op Java, bldz. 115 v. v.; ms. journaal van Van den Broecke).

1 In Van den Broecke's journaal staat nog: „Ondertijekent bij den conninck van Jacea, genampt Wijdruch Rama, Thomas Dael met sijnnen Raedt, en die vant fort voornoempt."

${ }^{2}$ Uit het Contractboek. - Van der Chijs neemt het over "van een oud afschrift op de Alg. Sekretarie te Batavia berustende." (T. a. p., bldz. 215.) 
Artijkelen geeyst bij de Raden leggende jnt fordt Jacatra, op den eysch ende versoeck van den koninck van Bantam in forme als volght.

Alsoo d'Koninck ons affeyscht het fort voorn ${ }^{t}$, omt selve aff te breken ende te raseren, sall hem t'selve bij ons overgeven ende in handen gelevert worden, om daer mede te doen als hem sall gelieven, mits ons vergunnende de conditien vorders genomineerdt.

Eerst voor all sall den Koninck gehouden zijn ons toe te zenden joucken, prauwen ende alles wat moghte nodigh zyn om ons ende onse goederen souder schade ende verhinderinghe [in] te schepen ende naer Bantam te voeren, ende ons hier voor Jacatra onderwegen offte op de rheede, mitsgaders tot Bantam, te bevryden van alle overlast ende molestatie, die ons door de Engelsche offte eenige andere moghte aengedaen worden.

Sullen wij mogen ook tot onser believen alldaer op de rheede te leggen, aen landt overgaen offte vertrecken, soo als de sake ende den tijt sall vereyschen ende dat, als vooren geseght is, bevrijdt van alle overlast offte ongevall ende sullen wij ons ook vervoegen bij ende mede jnt Fransche ' scheepken, den Koninck toebehoorende ende aldaer op de reede leggende, om onse joncken ende ons selffs daerinne en omtrent te onthouden ende soo ons als dan nogh yets moghte ontbreken, als verversinge ende andere behoefflyckheden, sall ons vergunt werden, met gelt te mogen kopen; zoo zullen wij ook tot ons believen mogen aen landt komen ende van daer weder te schepe-varen, wanneer het noodigh zall zyn, gelijck voor desen geschiedt is.

Dat alle het volck van wat natie zij zijn, als Holland ${ }^{\text {rs }}$, Negros ${ }^{2}$, Japonnesen, getroude ende ongetroude, sullen mogen met ons uijt het fordt te vertrecken, in volle geweer, vliegende vaendell, brandende lonten ende alle haer toebehoorende bagagie, zonder van eenige Javanen gevisiteerdt offte belett te worden.

Sullen wij mede uijt het fordt dragen, vrij ende onverhindert, alle de coopmansschappen ende comptanten, de Comp ${ }^{\mathrm{e}}$ toebehoorende, mits dat den Koninck daervan sall genieten een gereght vierde part, namentlijck vyff en twintigh vant 100 , ook mede uijt te voeren de helffte van alle het geschut, kruijdt, kogels met

1 Een der twee schepen van Dieppe, onder Charles de Nets.en Augustin de Beaulieu, was in 1617 aan den vorst van Bantam verkocht. (Tiele, Europeërs, VIII, bldz. 209, v.)

2 Wat onder dezen term hier verstaan wordt, is mij niet recht duidelijk. 
alle resterende toebehoorte, oock alle de provisie, victualie, montcossten ende haer toebehoorte als watervaten ende andere dingen daertoe noodigh, binnen 't fordt zijnde.

Dat hier tot Jacatra, als het fordt zall overgeven zijn, zullen mogen vrij ende liber blyven woonen 5 offte. 6 man, om te koopen arack ende andere provisie, onse schepen ende volck nodigh zijnde. t' Comptoir tot Bantam sall gestelt worden in forme en vryheyt, om met de Chineese ende andere natie te mogen negotieren, als mede van ${ }^{1}$ desen geschiet ende een comptoir toebehorende is.

Alle onse gevangenen, van hier vervoerdt ${ }^{2}$, zullen losgelaten, ontslagen ende vrij gestelt worden.

Ten laetsten sullen wij ook vermogen, eer van hier vertrecken, onse joncken met haer cleynste geschut, bassen ende steenstucken [te] versorgen tot defentie ende behullp voor ende tegen die geene, die ons moghten molesteren; sullen oock geen Javanen meer aen boordt off in de logie mogen komen, dan als de Holland ${ }^{\text {rs }}$ zelffs zullen gelieven, oock de joncken die op de rheede zijn liggende, niet bij ymandt anders dan door ons alleen bewaerdt werden.

Ditt alles sal den koninck van Bantam ons met eede bij den Allcoran ofte Mosaff ende met sijn zeegelle ende handteeken bevestigen ende versekeren, sonder argh offte list naer te komen ende onderhouden. Dit doende, zall hem onse fortresse ende genoemde in handen gelevert overgegeven worden. Actum int fordt Jacatra $9^{\text {e }}$ Februarij 1619.

\section{BANTAM.}

11 Maart 1619. ${ }^{3}$

De voorwaarden van 9 Februari werden te Bantam niet bekrachtigd. Bantam stelde meer besliste eischen van overgave der versterking, althans van hare slechting. De Nederlanders besloten thans, te blijven; den 27 Februari werd het besluit genomen, om „de plaetse tegen de heydense Javanen te behouden, door sulcke middelen als God verleend had of nog verleenen mogte, soo lange het in vermogen was." Verdere onderhandelingen met Bantam leidden tot onderstaand ontwerp-contract.

Het verdere verloop der Djakatra'sche aangelegenheden, de verdrijving der Bantammers, welke hunnen leenman van Djakatra uit zijn gebied hadden

1 "Vóór": zie Van der Chijs, Jakatra, bldz. 216.

2 Pieter Van den Broecke en de zijnen waren op last van Bantam uit Djakatra naar Bantam vervoerd.

3 Uit het Contractboek. 
verdreven en de stichting van Batavia (30 Mei 1619) zijn bekend. (VgL. Van der Chijs, Jakatra, bldz. 114, v. v.; De Jonge, Opkomst, IV, bldz. CX-CXIII; Tiele, Europëers, IX, bldz. 220-223, 226-227; Van Deventer, Nederlanders op Java, bldz. 118, vv.)

Contract ende verbondt gemaeckt tusschen Zijne Maij ${ }^{t}$ den koninck van Bantam ende d'E. Gecommitteerde wegen de Vereenighde Nederlandsche Oostjndische Compe tegenwoordigh jnt fordt op Jacatra.

Eerstelijck sall den koninck van Bantam gehouden wesen ende hem verbinden, ons ende d'onse, soo hier tot Jacatra als tot Bantam in de logie, te bevrijden voor alle overlaste ende gewellt van jnwoonderen allhier tot Bantam als der Engelse ende niet te gedoogen nogh toe te laten, dat op ons tegenwoord ${ }^{5}$ forth eenigh voorder geschut, t'zij door de Engelsche offte jnwoonderen van Bantam en hier, geplant en gestelt sall worden, maer ter contrarie alle middelen van hosstiliteijten te voorkomen ende ons alltsamen, als vooren geseght is, voor alle moetwillige beschermen.

Ons sall ook alle liberteijt ende vrijheijt, soo hier als tot Bantam, vergundt werden omme opentlycken onsen handell als voor desen te mogen 'dryven ende proffijt van onse $\mathrm{H}^{\text {ren }}$ Meessteren te betraghten, latende ondertusschen ons fordt in esse, ${ }^{1}$ alst jegenwoordigh is. Ende tot meerder versekeringe van t' voorschreven, zall ons Sijne Maijt tot onderpant als oosstagiers hier in ons tegenwoordigh fordt beschicken twee persoonen, te weten quiaij Nebe, geseijt Lacmoij ${ }^{2}$ ende Limko Abdull Gaffar offte den sabandar quiay agus Warga ${ }^{3}$ in zijn plaets, ten tijde dat dit ons tegenwoordigh contract in allen deele effect magh sorteren ende naergekomen kan werden.

Hier en tegen sullen de gecommitteerde van $d^{0}$ fordt gehouden wesen, geen Javanen te beschadigen offte tegen de jnwoonderen eenige hosstiliteijt te gebruycken, ende ter aencomste van hunnen generaell offte eenige haerder schepen, waerinne hun zonder pyryckell van overlast der Engellse offte andere zoude konnen embarqueren, de voorschreven sterckte te verlaten ende te raseeren. ${ }^{4}$

Zall ook den Coninck uit vrijen wille ende niet in schijn van

1 In wezen,

9 Vgl. Van der Chijs, Jakatra, bldz. 145.

s Kiahi mas Warga of agoes Warga. (Van der Chijs, Jakatra, bldz. 125, $\mathrm{v}, 129$.

4 Men had in onze versterking blijkbaar de bedoeling, de zaken slepende te houden tot Coens terugkomst. 
contract vereerdt ende toegesonden worden, te weten soo haest de voorschreven twee personen in ostagie sullen bekomen hebben, tgereghte vierdepart van alle des Comp ${ }^{8}$ goederen int voorschreven fordt berustende offte naer taxatie desselffs de weerde van dien, als mede ter comste van den voorschreven gener ${ }^{1}$ offte de schepen de volcomene helfft van alle het groff geschut ende steenstucken.

Item tot voordere vriendtschap ende eenigh ${ }^{t}$ belooven ende zweeren wij ondergeschreven, den koninck van Bantam ende den zijnen voor alle gewelt der Engelse ende sijner vyanden te bevryden ende des van noode zijnde hem in alles te assisteren ende tot meerder versekeringh van dit voorschreven sullen onse vrienden tot Bantam hun alldaer zoo langh onthouden, mits dat haer den handell van nu aff vergundt sall worden. Sullen ook de vrienden Hend ${ }^{k}$ Jansz. van Uffelen ende Dirck Lamberts, voor desen van Zijn Maijt herwaerts gesonden ${ }^{1}$, hun opt spoedighste, soo haesst alles volcomentlijck gecontracteerdt ende bij den Coninck onderteekent sall wesen, weder naer Bantam vervoegen, op dat alles met meerder sinceriteijt en sonder bedrogh naergekomen magh worden.

Dit alles hier voornoemt belooven ende zweeren jck, pangaran Arij Rana de Mengala ${ }^{2}$ bij mijne konincklijcke waerheijt ende wij, gecommitteerde present jnt fordt op Jacatra, in alleen deelen naerkomen, ende te versorgen dat alle naergekoomen zall werden. Jn kennisse der waerh ${ }^{t}$ hebben hier van twee eender jnhoudt laten schrijven ende beijder met eijgener handen onderteekent, d'eene berusstende onder mij, koninck ${ }^{3}$ vau Bantam, ende d'ander onder ons, voorschreven gecommitteerde. Aldus gedaen zonder argh offte list int fordt Bat ${ }^{a}+$ op Jacatra desen $11^{\mathrm{e}}$ Meerdt $\mathrm{A}^{0}$ 1619. Was onderteekent Pieter van Raey, Jan van Gorcum, Henrick Janszoon, A. G. Hullsebos, Jvert Hermanszoon, Van Uffele, J. Coetely, Abram Stricken, Hendrk Hermsen.

\footnotetext{
1 Vgl. over hen Van der Chijs, Jakatra, bldz. 111, 114, 119, enz.

2 Pangeran Aria Rana di Menggala, Bantam's rijksbestuurder. (Van Deventer, t. a. p., I, bldz. 75).

${ }^{3}$ Dit komt niet overeen met de veronderstelde onderteekening van den Rijksbestuurder.

${ }^{4}$ Van Raeij en de zijnen hadden het Nederlandsche fort den naam Batavia gegeven. (Volgens Van Deventer, t. a. p., bldz. 119, juist den 11 Maart, den datum dus van deze concept-overeenkomst. Vgl. De Jonge, Opkomst, IV, bldz. CXII).
} 


\section{KUST VAN KOROMANDEL.}

25 Juli 1619. 1

Bij den ferman van Augustus 1606 ( $\mathrm{n}^{\circ} \mathrm{XIX}$ ) waren de in- en uitgaande rechten, door de Nederlanders te Mazulipatam te betalen, bepaald op 4 pet. Later, in 1612 , werd hiervoor een vast bedrag overeengekomen, nl. 3000 pagoden, ter waarde van ongeveer 25000 gulden. De waarde der pagoden was in Mazulipatam niet altijd gelijk. (Vgl. Havart, Cormandel, II, bladz. 100; Valentijn, IV, I, bladz. 358). In 1617 werd deze overeenkomst bevestigd. (Vgl. Havart, II, bladz. 100-102; Van Dijk, Wemmer van Berchem, bladz. $20-24,36$, v.) Ook thans weder in 1619 . De groote waarde van den Koromandelschen handel voor de O.1. C. werd door den lateren G.G. Hendrik Brouwer eens als volgt omschreven: „De Custe van Coromandel (is) den slincken arm van de Molucos ende omliggende eylanden, gemerckt sonder doecken, van daer comende, de negotie doot is in de Molucos." (Onuitgegeven brief aan de Bewindhebbers, Juni 1612 op het R. A.)

Firman ons door den-koninck van Goleonda toegezouden.

Jck sende een firman, dat de geheele werelt waerdt is. aen de Hollanders, doordien Etmachan ${ }^{2}$ van de band ${ }^{\mathrm{r}}{ }^{3}$ van Masulypatam mij van den handell der Hollanders heefft onderreght.

Jck hebbe gelicentieerdt, dat de Hollanders, gelijck voor desen ${ }^{4}$ waer het ende met wien haer geliefft, mogen handelen, koopen ende verkoopen, mits betalende drie duysent pagoden, ${ }^{5}$ jaerlijex vrij van alle tollen ende jmpossten sullen zijn ende wie tegens dit firman yets attenteert off wie een ander firman hiertegens soeckt, zall als een verrader van den Koninck gehouden werden.

Zoo haesst dit firman comt, laet de Hollanders in haer huys gaen

1 Uit het Contractboek.

2 Havart, t.a. p., bldz. 102, heeft: „Aitemaedcham, opziender van Mazulipatam". - Het exemplaar in het Contractboek der Kamer Zeeland, dat gecopiëerd is in de tweede helft der $18^{\text {do }}$ eeuw, heeft: „Ayternaad Hawaldaer van Mazulipatam". Over de aanzienlijke waardigheid van hawaladaar van Mazulipatam, welke de stad pachtte van den vorst van Golkonda en haar namens hem bestuurde, zie men Havart, I, bldz. 225-227. (Vgl. HobsonJobson, p. 313, 806, sub voce „Havildar”.)

3 Bandar: zeehaven.

4 Vgl. hierachter (Aanhangsel) de documenten van 1614 en 1617, overgenomen uit Havart.

5 Havart, t. a.p., heeft "oude Pagoden". 
ende haer negotie als voor desen drijven, sonder yts meer te gedencken, dat voor desen is gepasseert. ${ }^{1}$ Desen $25^{\mathrm{e}} \mathrm{Julij}^{\mathrm{A}^{\circ}} 1619$.

Van dit firman hebbe Cherceyll ${ }^{2}$ tot getuijge genomen.

\section{AMBON.}

\section{Julịj 1620. ${ }^{3}$}

Het contract van Februari 1605 ( $\mathrm{n}^{\circ}$ XIV) was hernieuwd geworden den 9 Augustus 1609 (n० XXIX). Frederik de Houtman, die in April 1620 op de Ambon-groep verscheen, en Herman van Speult vonden wenschelijk, dat deze verdragen nog werden bevestigd en aangevuld. (Vgl. Tiele, Bouwstoffen, I, bladz. L, 255, 267.) „D'Mooren hebben hier oock voor een gebruyck gehadt dat [zij] deese inwoonders [nl. „die aen't Casteel woonen"] d'frayste vrouwen sochten te ontrecken, waermet haer soo verknochten aen malckander, dat sy ter gelegender tyd al 't samen wel Hiettesen souwden hebben geworden." De gouverneur Van Speult had daarom een hooge boete gesteld op het trouwen van inlandsche Christenvrouwen met Mohammedanen. (Onuitgegeven missive van A. Gysels aan de Bewindhebbers, 5 Augustus 1619. Gysels was ambtenaar der O. I. C. op Ambon.) Alleen de "Ampliátie" van het contract laat ik hier volgen. ${ }^{4}$

Waar by nog deze Ampliatie gekomen is.

En overmits hier eenige fauten begaan zyn, als dat die van Hitoe eenige Christen vrouwen genomen, en haar Moors gemaakt en getrouwd hebben, en opdat zulke fauten niet meer zouden geschieden, hebben de Gouverneurs ${ }^{5}$ Frederik Houtman, ende Herman van Speult, met de Orang Kaja's geresolveerd, dat zoo wie van nu voortaan eenige Christen-vrouwen, zonder weten van den Gouverneur, van Amboina haald, zal verbeuren 1000 petoolen voor 't Kasteel; ende zoo de Christenen van 't Kasteel eenige Moorse vrouwen van Hitoe, of daar omtrent, zonder consent haalden, zullen in gelijke

1 Havart, t.a.p., teekent hierbij aan: „Men moet weten, dat in die tijd de Hollanders uit Mazulipatam gevlugt waren." Inderdaad waren er onaangenaamheden voorgevallen tusschen de Nederlanders en de Mohammedaansche autoriteiten van die stad en hadden de onzen in de eerste helft van 1619 haar verlaten (Valentijn, V, 1, a, bldz. 61.)

2 Geen persoonsnaam, maar de titel van een hooggeplaatsten ambtenaar van den sultan van Golkonda (rijkskanselier of grootzegelbewaarder). (Vgl. Dagh-Register 1624-1629, bldz. 33; Havart, I, bldz. 159; II, 212, enz.)

3 Overgenomen uit Valentijn, Ambon, II, b, bldz. 43, v.

4 Op bldz. 33 hiervóór $\left(5^{\mathrm{e}}\right)$ staat: ${ }^{4} \mathrm{Of}$ het geviel, dat de Hollanders, eenige oorloch doende". Valentijn heeft hier: „Eenige overlast".

5 Vgl. Tiele, Bouvstoffen, II, bldz. 255, noot 1. 
poene vervallen, ende zoo het voor de tweede reis geschied, zullen zonder genade aan den lyve gestraft worden.

Geschreven in presentie van den Heer Gouverneur Houtman, en den heer Gouverneur Herman van Speult, Capitein Hitoe, den Orang Kaja Pati Toeban, ${ }^{1}$ den Orang Kaja Tanahitoemeseng, ${ }^{1}$ ende den Orang Kaja Tatohatoe, ${ }^{1}$ den eersten Juli A ${ }^{0} 1620$.

Was onderteekend, Frederik Houtman en Herman van Speult.

\section{VII. DJAMBI.}

\section{Juli $1620{ }^{2}$.}

Coen had, om in den peperhandel niet afhankelijk te zijn van Bantam, betrekkingen aangeknoopt met peperhavens op Sumatra, o. a. in 1615 met Djambi (Tiele, Bouwstoffen, I, bldz. XXXI; De Jonge, Opkomst, IV, bldz. 33), waar in hetzelfde jaar een Nederlandsche loge werd gebouwd, iets wat aan den Engelschen, die blijkbaar óók in 1615 voor 't eerst in Djambi kwamen, al spoedig eveneens werd vergund. Toen elders in den Archipel de verhouding tusschen Nederlanders en Engelschen steeds minder gunstig werd, deed dit ook zijn invloed in Djambi gevoelen. $\mathrm{Na}$ de bekende vereeniging tusschen de Nederlandsche en Engelsche Compagnieën in 1619 (Vgl. De Jonge, Opkomst, IV, bldz. CXXIV_CXXVI) werd de officieele verhouding beter (De Jonge, Opkomst, IV, bldz. 126, v. - Tiele, Europeërs, VIII, bldz. 215, IX, bladz. 247) en dit verklaart onderstaand contract, dat vooral ten doel had, het opdrijven van den peperprijs te voorkomen. (Onuitgegeven missive van Coen aan de Bewindhebbers van 8 Jan. 1621.)

A consulltacion off agreement maghe ${ }^{3}$ in Jambe the $24^{\text {th }}$ Julio 1620 on the behallffe off the two Companyes: orn ${ }^{3}$ hon $^{\text {ble }}$ jmployers off England and the Netherlands tradinge the East Indias, etc ${ }^{\mathrm{a}}$.

Weheras it hath pleased allmightye God of $\mathrm{H}^{\text {is }}$ gratyous goodnes, to ijoojne in looue and amytie the two worthy Companies off England and the Netherlands, our Hon ${ }^{\text {ble }}$ jmployers in the trade and commerce off India;

and to avoude + the troublesome dissintions and emulations which) former experience hath manivessted to have beene amonght the servants of the same companyes in all $\mathrm{p}^{\text {ts } 4}$ and places where

1 Pati Toeban, orangkaja Tanahitoemesing en orangkaja Tatahatoe behoorden tot de vier hootden van Hitoe. (Zie hiervóór, bldz. 31, noot 4.)

2 Uit het Contractboek.

s Made? - Our? - De tekst is zéér bedorven.

4 Avoid? - Ports. 
both ptyes were and haue beene resident, as allsoe to our better knowleege and experience hath beene pformed heere jn Jambe, not onelye in te ventinge and sale of commodities brought hither, but allsoo in pcuringe (?) and strivinge on both sides to jnvest himeselffe $\mathbf{w}^{\text {th }}$ the comoditie off this place, beinge pepper, raysinge and advancinge the prices one upon another to the unspeakable lose, hinderance and damage off both Companies, our hon ${ }^{\text {ble }}$ jmployers.

To hinder and absolutelye debarr all such (?) jnconveniences, as allsoe being the expresse order off both our principall, the president for thee English Companaye and the generaell for the Netherlands Companye, both resident in Jacatra ${ }^{1}$, that neyther off us, our selves nor anye one for us, shall buy or couse to bought or procure any pepper to anye off our $\operatorname{Comp}^{e}$ at or above the rate off 8 rialls, eyght per pecule ${ }^{2}$, except upon some enew (?) consideration or just occasion for the same, allwayes provided, itt be $\mathrm{w}^{\text {th }}$ consent and fixenige (?) of both sides and note of her wise (?)

Alsoe beinge agreed and concluded betweene both companies, our honble jmployers at home, ratified and confirmed bij both principalls, the President aend Gener at Jaccatra, that the traet off this place, als off all other, where wee shall bee both setled, to be equallye reparted and divided in hallues, allbeyt the one emcompasse (?) and purtchase a greated ${ }^{3}$ some or quantitie off pepper more then the other, and the same ptije shall be contented aend not dijnije to share the same equallye and at the same rates $w^{\text {ch }}$ cost hime, whoudt usinge anij sijnijster or jndirect meanes, soe that eagh Comp ${ }^{\mathrm{e}}$ off our honble jmployers may enioij their desire accordinge to theyr agreements maghe.

Allsoe wee hould it requisite, that uppon any occation off schippinge pepper as upon the aryvall off any schippe, jonke or otherwijse, that neijther off us nor anije for us doe jmbarke, schippe or cause to bee jmbarked or schipped or carrijed out off eijther off our goodownes ${ }^{4}$ or houses anye pepper here in Jambe w ${ }^{\text {thout }}$ giuinge tene ${ }^{5}$ notice to ouse ${ }^{6}$ another, wher one or two off eagh

1 Batavia.

2 Pikol: thans pl.m. 62 kilogram.

3 A greater?

4 Goedang of gědoeng $=$ pakhuis.

5 True?

6 One? 
side may bee appoincted to take true notice ther off, wherbye noe jealousie or difference may aryse to the discontinuance off our loues aend amijtie with another. Ffurthermore wee hould convenient, that iff eijther off us schall hane jnvested all is ${ }^{1}$ cargason, both off goes ${ }^{2}$ vendable aend moneijes jn pepper, that then and not before te other haueinge a cargason off moneijes oll goes ${ }^{3}$ or both, may and shal be lauwfull for hune ${ }^{4}$ tho employe the same for the pticulier accompt off his employers, provided that zee ${ }^{5}$ giues notice tho the other ptye, that a just accompt be kept aparte.

Allsoe is requisite toreniers (?) considaracons, that neyther off us nor anye for us schall barganije, ${ }^{6}$ buy or pcure for his avne pticuler Comp $^{e}$ anije pepper out off anije jonnck or prowe ${ }^{7}$ what soeuer, wthin this riuer or road apptayninge or belonginge to Jambe wthout a joynt consent off both ptyes and iff anye shall be soe bought, to be equallije shared in hallues and $\mathrm{w}^{\mathrm{hr}}$ off eijther parthye schall breake or cause to be brooken anije off the forementioned agrements, shall bee held as a disturber off the comende ${ }^{8}$ peace and bee referred tho the principals att Jacatra for his censure accordinglije.

\section{KUST VAN KOROMANDEL.}

28 Augustus 1620. ${ }^{9}$

$\mathrm{Na}$ de gebeurtenissen van 1612 (zie hiervóór, bldz. 100-104) hadden de Nederlanders zich in Pulicat staande gehouden, niettegenstaande de inlandsche autoriteiten zich niet in elk opzicht hielden aan het verdrag, den 12 December van dat jaar gesloten, niettegenstaande ook de tegenwerking der Portugeezen. Zóó werden de kosten van het opbouwen der "begonnen fortresse" ten slotte door de O.I. C. zelve gedragen. Maar zij wèrd voltooid (1613) en met een garnizoen voorzien. Echter was het niet zonder groote moeilijkheden, dat het pleit werd gewonnen en „extraordinarie onredelijoke schenckagie" kon niet worden gespaard. De moeilijkheden werden vermeerderd door de onophoudelijke binnenlandsche twisten

1 Its.

2 Goods?

3 And goods?

4 Him ?

s $\mathrm{He}$ ?

6 Bargain.

7 Pěrahoe, prauw.

8 Common?

9 Uit het Contractboek. 
onder de inlandsche aanzienlijken, niet in toom gehouden door een krachtig centraal bestuur. Een deel van hen trok partij tegen de onzen en het kwam tot vijandelijkheden, welke de O.I. C. gelukkig te boven kwam. Het belang van dit centrum van handel werd steeds meer door de onzen ingezien; vooral de bekende Kustdoeken, zoo gewild in den Maleischen Archipel, kwamen dáár ter markt van de versehillende deelen van de Kust van Koromandel en elders en waren in die dagen voor onze commereie van groote beteekenis. Ook de Engelschen kwamen er handeldrijven. (Vgl. Van Dijk, Wemmer van Berchem, bldz. 27-46; Foster, Madras, p. 2,f.; W. W. Hunter, History of British India, I, p. 297, 369.)

Contract gemaeckt door Jtteragie, ${ }^{1}$ heer over de Ommelanden van Palliacatta, ter eenre ende Assly Patclitt Groa ende Ragie Chitty ter andere zijde voor den tijd van drie jaren, jngaende den $28^{\mathrm{e}}$ Augustus $\mathrm{A}^{\circ} 1620$ over gouverno deser stadt Palliacatta als 't landt, daer onder sorteerende. ${ }^{2}$

Credentie brieff door Jnteragie aen d'onse gegeven, slaende op 't voorgaende accoordt, den 28e Augustus 1620.

Jck Gouber Interagie, die over 4.0 Jentijsche $^{3}$ mijlen landts gouvernere, hebbe dese brief van credentie gegeven aen den capitayn moor der Hollanders. Allsoo jck omtrent Paliacatta was gekomen wegen de visiadores, ${ }^{+}$ben ook int fordt bij den Capytayn Moor gekomen ende alles dat voor desen tijt was gepasseerdt " met den anderen affgedaen; ende omdat Pederagie ${ }^{5}$ niet naer behooren met mij heefft gehandelt, soo heeffț den capitayn moor voorn ${ }^{t}$ den voorschreven Pederagie mij doen visiteren, ${ }^{7}$ derhalven jck hem door tusschenspreeken van de Capytayn de visie $^{8}$ hebben laten behouden, mits dat hem voortaen sall dragen ende gouverneren jn de stadt als ten tijde van Obayana ${ }^{9}$ ende jnt landt daer de visie over heefft

1 Vgl. over hem Van Dijk, t.a.p., bldz. 30. Hij was nog altijd een der leiders van de onder elkander strijdende partijen in de binnenlandsche twisten.

2 Deze overeenkomst kan ik weglaten, omdat zij voor ons van geen belang is. Wel neem ik het dáár onderstaand verdrag op.

$s$ Hier vermoedelijk inlandsche mijlen. Het woord is afgeleid van het Portugeesche "gentio" = Heiden, vervolgens meer bepaald de inheemsche bewoners van Vóór-Indië. (Vgl. de plaatsen bij Hobson-Jobson, p. 280.)

"Portugeesch "visitadores" = opzichters ? De bedoeling is mij niet duidelijk.

${ }^{5}$ Vgl. Van Dijk, Wemmer van Berchem, bldz. 30. Er waren vijandelijkheden gepleegd tusschen hem en de O.I. C.

6 Een der visiadores in Pulicat.

7 Bezoeken.

${ }^{8}$ De beteekenis hiervan in ons verband is mij niet volkomen duidelijk.

9 Zie hiervóór bldz. 101, noot 6 . 
naer oude cosstuijme ende gebruijcke. Dit alles hebbe vergunt aen Pederagie. Dies heefft den voornoemde cap $^{t}$ moor ook toegelaten, dat [ik] ' eenigh volck tot vijsie in de stadt sall laeten, ende sall desen soo lange van valido ${ }^{2}$ wesen als Pederagie het boven geschreven sall onderhouden; ende soo yets in de stadt offte landt daertegens doet, sall den Capiteyn Moor mijn in mijne gereghtigheit mainteneren ende Pederagie niet assisteren. Boven de voornoemde Pederagie sall ook geen ander vysiadoor daar in de stadt laten wesen.

Ende jngevalle eenige vyanden op 't fordt ${ }^{3}$ offte op de stadt ijets attenteeren, beloove ick de selve met alle mijn maght te beschermen ende te assisteren. Desen van geloove hebbe ick gegeven. Was onderteyckent S. v. D. A. P.(?) ${ }^{4}$ met de name van zijnen ${ }^{5}$ Godt.

\section{BANDA.}

\section{Maart 1621 ? 6}

De gebeurtenissen op de Banda-eilanden volgden den weg, die tot het bittere einde zoude leiden, zonder dat de telkens gesloten verdragen en overeenkomsten daarin duurzame verbetering ten goede brachten (Zie hiervóór, $\mathrm{n}^{\circ} \mathrm{LI}, \mathrm{LIV}, \mathrm{LVII}$.). De toestand werd verergerd, als de Bandaneezen kans zagen, de muskaatnoten aan andere handelaren te verkoopen: Europeesche of inlandsche. Zóó brak Slaman (hiervóór, no LVII) in 't begin van 1620 met de Compagnie. (Tiele, Europeërs, IX, bldz. 235.) Toen nu Coen in Januari 1621 zijn bekenden oorlogstocht naar de ongelukkige eilandengroep ondernam en daar forscher optrad dan ooit, werden Slaman en andere streken gedwongen, het hoofd in den schoot te leggen. (Van der Chijs, Banda-eilanden, bldz. 109, v.v.; Tiele, Bouwstoffen, I, bldz. XLII, v.v., 272 , v.v. ; Europeërs, IX, bladz. 252, v.v.) Niet onwaarschijnlijk, al is het niet zeker, is onderstaand contract toen met Slaman en eenige andere streken van Groot-Banda en Rosengain gesloten.

Volghen d'artikelen, die syluyden ons belooft hebben, als volcht:

1. Dat sy altsamen sullen sweeren ende bekennen de Ed. Mog.

I Dat deze inlassching de juiste is, blijkt uit een ander exemplaar van deze overeenkomst, welke in 't Contractboek voorkomt sub dato 28 Augustus 1624, een blijkbaar foutieven datum.

2 Portugeesch $=$ van kracht.

3 Het fort Geldria nl.

4 In het ander exemplaar staat: „S. o. d. S. P." De verklaring dezer letters kan ik niet geven.

5 In het ander exemplaar: "mijnen Godt."

o Overgenomen uit Van der Chijs, Banda-eilanden, bldz. 183. 
Heeren Staeten ende Synne princelycke Excell. voor haer ende haerder naecomelinghen hooft ende heeren, beloovende deselve in aller getrouwicheijt (sonder eenighe listicheit) te dienen, alsoock mede aen den Gouverneur, die van den Generaal ${ }^{1}$ hier in synne plaatse gelaeten sal worden, ofte oock die hier by den Gouverneur in syne plaetse gestelt soude moghen worden.

2. Dat se haer lant mette casteelen ende vruchten geven in handen vau den Generael, gelijck sy oock by deesen waerelycken (sonder eenigh bedroch) in synne handen geven, sonder dat iemant anders daarop iets sal hebben te pretendeeren, bekennende hiermede de Ed. Mog. Heeren Staeten ende synne Prinselycke Exell., ende geene anderen voor haere hooft ende wettelycke Heeren.

3. Tot een erkentenisse van dien sullen sy haeren heere betaelen de thienden van alle haere vruchten.

4. Sullen haere vruchten nergens te coop brenghen als op Neyra ende Poulluay aen de cooplieden aldaer; sullen oock leverbaer goet moeten leveren.

5. Sullen oock geen sterckten moghen maecken, maar sullen gehouden wesen op 't strang te commen wonen. ${ }^{2}$

6. Indien den Gouverneur van Banda eenighe hulpe van doene heeft, tsij in oorloghe off int maecken van sterckten, sullen hem (soo veele mogelycke) terstont helpen, doch dat volgens de belofte haer gedaen. ${ }^{3}$

7. Sy en sullen selve geen recht moghen doen, maar, alsser iet voorvalt, sullen den Gouverneur aandienen, dewelcke dan mette Orangcays van 't land de saecke sal affdoen.

8. Soo beloven ende sweeren sy, haer te houden tegens ${ }^{*}$ haeren heere, gelyck een goede ende oprechte gemeynte betaemt, ende sonder eenighe list naer te commen alle de ordonnantiën ende geboden, die hy hen geven soude.

9. Dit alles sweeren sy luyden niet alleen voor haar selven, meer voor alle de gene, die op haer lant sullen commen wonen, belovende oock te helpen, dattet van andere naergecommen soude worden, ende te helpen straffen, die daertegens sullen comen te doen.

1 Gouverneur-generaal.

2 Het meer door de onzen gebruikte middel, om de inlanders gemakkelijker onder bedwang te houden.

$s$ Deze laatste zinsnede is mij niet duidelijk.

4 Ten aanzien van, tegenover. 


\section{BANDA.}

9 Mei 1621. 1

Hoe óók poeloe Roen zich aan den wil van Coen onderwierp, is bekend uit de bij het voorgaande contract aangehaalde bronnen en literatuur, waar ook zijn behandeld de bloedige gebeurtenissen gedurende en nà het sluiten dezer contracten van Maart en Mei 1621.

Jan Pieterss. Coen, Gouverneur Generaal, wegen de hooge Mogende Heeren Staten Generaal, sijne princelijcke Excellentie, prince van Orange etc. ende Heeren bewinthebberen der Generaele Oost-Indische Compe der Vereenichde Nederlanden jn Indien,

die van Puluron in genade aengenomen hebbende, heeft haar vergunt opt selvige eylant te mogen blijven woonen op naer volgende conditien.

In deu eersten, dat d'Orangcays ende Overhooffden vant eylant Puloron sullen beloven ende sweeren; gelijck sij bij desen uyt den naem ende van wegen de gantsche gemeente op haeren Moessaf alle te samen ende elck van hun int byzonder belooven ende sweren voor haer ende haere nacomelingen, de Hoge Mogende Heeren Staten Generael ende sijn Excell. Prince van Orange etc. ende de Heeren Bewinthebberen der Generale Oost-Indische Compagnie van de Vereenichde Nederlanden voor haere Souveraine ende gebiedende Heeren t'erkennen, gehouw ende getrouw te sijn, gelijck mede den Heer Gouverneur Generaal, sijnen Luitenant Gouverneur alhier residerende ${ }^{2}$ ofte andere gesubstitueerde overhooffden ende dat alle haer E. ordonnantien nacomen sullen.

Sullen dien volgende de voorsz. Orangcayen ende Overhooffden van Puloron verclaeren dat sij 't eylandt genoempt Puloron, stercten, steden ende vruchten vandien, gelijck die van Slamma, Wayer, Demmer, Comber ende Rossangijn gedaen hebben ${ }^{3}$ vąn haere voornoemde plaetsen, aenden Ed. Heer Gouverneur Generael suyver ende daerop niemandt iets heeft te pretenderen, sinceerlijck sonder arch ofte list overgegeven ende opgedragen hebben voor haer ende haere naercomelingen, gelijck sij tselve eylant ter goeder trouwen opdragen ende overgeven mits desen. Dat sij dienvolgende geen ander princen off potentaten erkennen off houden voor haere Souveraine gebiedende

1 Overgenomen uit Tiele, Bouwstoffen, I, bldz. 284-286.

2 M. a. w. onze gouverneur van Banda.

${ }^{3} \mathrm{Zie}$ het voorgaande contract. 
ende wettige Heren als de Hooge Mogende Heeren Staten Generael der Vereenighde Nederlanden ende haere gesubstitueerde over dese eylanden.

Sullen in erkentenisse aen haeren Heere den tienden in alle de vruchten die voornoemde eyland Pouloron opbrengt betaelen.

Sullen alle de nooten ende foulie wel geconditioneert op Poulouay oft Nera te coop brengen aende geene die van wegen den Gouverneur daertoe gesteld sijn ende aen andere geene vercoopen moghen.

Sullen geen versterckinge mogen maecken ende beneden t'geberchte blijven woonen.

De Gouverneur, vant landt eenige assistentie van noden hebbende t'sij ten oorloge off fortificatie in deze landen, sullen de voorsz. onderdanen gehouden wesen datelijck soo veel doenlijk t'assisteeren.

Sullen niet vermogen justitie t' zij int civil off crimineel 't exerceeren, maar sullen aenden Gouverneur voorsz. recht versoecken, die ten overstaan van d' Orancays van do eylandt alle voorvallende saecken sal decideren.

Sullen voorder beloven ende sweren, dat sij haer in alles tegen haere voorsz. bescherm ende gebiedende Heeren als goede ende getrouwe onderdanen toestaen, dragen, dese ende haerer E. ofte haerer E. gesubstitueerde statuiten ende ordonnantien sonder eenich tegenseggen ofte wederspannicheyt sullen aennemen ende in alles naercomen, 't welck de voorsz. Orangcayen ende overhooffden beloven ende sweeren sullen, niet alleen elck voor haer selven, maar oock te helpen bevoirderen dat het bij andere onderhouden worde, ende de Gouverneur tassisteren, de contraventeurs vandien te straffen.

Toirconde vant welcke d'Orancayen ende alle die op Pouloron woonen ofte naermaels souden mogen comen woonen dese voorsz. articulen hebben beswooren t' onderhouden ende naer te comen ende hebben oversulcx dese met eygen handen onderteekent.

Int schip Nieuw Hollandia, leggende in d'eylanden Banda, adij 9 May $\mathrm{A}^{\circ} 1621$.

(Volgen de onderteekeningen in Arabische karakters).

Dit is een schrift van de Orangcayas van Poulon Ay ${ }^{1}$ ende Poulou Run aen de Generael, den welcken Godt de Heere segenen wil tot alle plaetsen.

1 Een groot deel der bewoners van $\mathrm{Ai}$ waren naar Roen gevlucht na de verovering van Ai door Lam in 1616. (Vgl. contract LI; Tiele, Europeërs, bldz. 178.) 
Voorders bidden wij aen den Generael om dese acht artijckelen te onderhouden opdat daer geen twist meer en ontsta, want alreede alle de Orangcayas van gantsch Banda sijn met den Generael geaccordeert, het gantsche lant van Banda te geven aen den Prince van Hollant in handen van den Generael. Alsoo hebben oock gedaen alle de Orangcayas van Poulou Ay ende Poulou Run, ende hebben het lant van Poulou Run gegeven aen den Prince van Hollant in handen van den Generael. Daerom bidden wij altsamen aen den Generael te willen beloven dese acht artijckelen te doen achtervolgen, opdat hier nae geenen twist meer en ontsta, opdat oock den Prince van Hollant een Heere blijve over tgansche lant van Bauda, soo lange de werelt staet; bidden derhalve altsamen aen den Generael het voorgaende ${ }^{1}$ ons te willen beloven.

Eerstelijck onse ${ }^{2}$ religie, datse ons geen over[last] in onse religie en doen, maer dat wij volgens onse religie mogen leven ende de Hollanders volgens de hare.

Ten tweeden dat niemant aen ons vrou en kinderen overlast en doe.

Ten derden dat niemant in iemants huys en come om quaet te doen.

Ten vierden dat niemant onverdient geslagen en werde; indien de Bandanesen, ${ }^{3}$ datse met recht gestraft werden.

Ten vijfden dat niemant het sijne ontrooft en werde tegen zijnen danck.

Ten sesten dat niemant gedwongen en werde tot eenich werck, want wij altsamen tot sulcken werck niet gewent en zijn.

Ten sevensten en laet ons niet ter oorloge brengen in andere landen maer indien eenige vijant in Banda comt, soo sullen wij met de Bandanesen * t'samen met de Hollanders de vijanden tegenstaen.

Ten achtsten indien eenige Bandanesen bij de Hollanders quamen loopen, datse die sullen wedergeven, ofte indien eenige Hollanders bij de Bandanesen quamen datse die oock sullen wederleveren, opdat (?) daernaer geen twist meer en ontstae ende geen misbruycken meer en geschieden tusschen de Bandanesen ende Hollanders, opdat den

1 Natuurlijk een schrijffout voor: „volgende".

2 Van der Chijs, t.a.p., blz. 129, noot 3, teekent hierbij aan: „De voorwaarden hebben kennelijk een Bandaschen, geen Nederlandschen oversprong". Al weder een bewijs, dat de Bandaneezen wel degelijk wisten wat zij onderteekenden. (Vgl. hiervóór, bldz. 25, noot 1). Trouwens, beide documenten zijn ook in 't Maleisch opgemaakt. Zie hierachter, blz. 166-170.

3 Hier is blijkbaar iets uitgevallen, maar de bedoeling is op te maken uit den Maleischen tekst: „dat, indien een Bandanees straf verdient, die straf na gehouden beraadslaging worde opgelegd."

${ }^{4}$ Bewoners van Groot-Banda: is hiermede vermoedelijk gemeend. 
Generael volcomelijck het lant van Banda mach goet doen soo lange de weerelt staet, opdat den name des Heeren Generaels mach verbreyt werden in allen plaatsen, soo wel inde landen bovenswints als benedenswints gelegen. Dat oock desen handel des Generaels niet verbroken en werde, so lange de weerelt staat. Dit bidden wij altsamen dat ons den Generael belove, want de misbruycken van dese acht artijckelen en connen wij niet dragen ${ }^{1}$ ende daer soude twist wt ontstaen tusschen de Bandanesen ende Hollanders.

Daerom geven wij altsamen met reynder herten te kennen aen den Generael, want wij hebben gehoort het gebot ende wille des Generaels om t'lant Banda te onderhouden soo lange de weerelt staat. Ende indien de Generael noch sulx begeert, wij begeeren sulx oock duysentfout ende van herten, gelijck den Generael wil. Daarom bidden wij aenden Generael dat dese acht artijckelen niet overtreden en werden opdat de genoechdoeninge ende oprechticheyt van den Generael over den gantschen aertbodem mogen gehoort werden ende alle landen zijn woort mogen volgen. Dit selve weet den Generael wel, maer om dat wij reyn van herten zijn, soo helpen wij het den Generael alleen gedencken, want onse oprechticheyt is bij de menschen vergeten, alleen en heeft se Godt niet vergeten. Wat valter echter nu meer te beraetslagen bij den Generaal ons aengaende? De daet des Generaels behaecht ons duysentfout dat hij het lant Banda onderhouden wil. Daerom geven wij lieden altsamen dit aenden Generael met reynder herten te kennen ende bidden den Generael, dese acht artyckelen te onderhouden, opdat de handeling des Generaels mogen bestendich blijven tot in eeuwicheyt, soo lange de werelt staet.

Voorder indien den Generael onse aller bede aenneemt van dese acht artijckelen, soo versoecken wij daervan een schrift vanden Generael om voor ons te houden, vreesende off den Generael wechginge ende een ander Generaal quame ende dat de handelingen van desen Generael niet overtreden en werden, vreesende noch voor eenigen twist. Daerom bidden wij altsamen vanden Generael dat hij dit belove opdat geen quaet meer en geschiede. Dit alleenlijck, wat sal dan den Generael, meer beraetslagen als het laut van Banda te versorgen, want het recht van Banda is nu in des Generaels handen; alleenelijck staet het t'sijnen bevele ende den Generael de beloften van den Orangcayas van Poulou ay ende Poulou run

1 De Maleische tekst beteekent: "want de handelingen in de 8 artikelen vermeld, kunnen wij niet dragen." 
raeckende dese acht artijckelen aengeuomen hebbende, niemant en mach dan meer des Generaels geboden verbreecken ofte omstooten. Aldus gedaen in 't schip Nieuw Hollandia desen $9^{\text {en }}$ Mey a $a^{0} 1621$.

Voorders dese acht artijckelen heeft den Generael aenden Orangcayas van Poulou ay ende Poulou run met trouwe beloften gegunt; niemant machse verbreken; alle de Gouverneurs van Banda off eenige andere sullen volgen dese acht artijckelen, gelijckse den Generael belooft heeft, geen andere en mogen de selve ook overtreden want den Generael heeft het belooft aen alle de Orangcayas van Poulou ay ende Poulou run. Actum als boven.

\section{J. P. Coen.}

Hieronder volgt de Maleische tekst der beide bovenstaande stukken.

Jan Pietersz. Coen, Gouvernador Generael deri pada prince Orange, dengan orang caya caya sacalien deri negri Hollande, souda bri ampon pada orang Poulourun, lagi souda cassie padanja doudoc de negrinja Poulou run, tatapi deanja tourut parácara ini jang comedien.

Sa paracarra orang caya caya lagi nang sjappa ${ }^{1}$ capalla deri negri Poulou Run djandji lagi basompa deri pada diaor: ${ }^{2}$ poụ̣ja raijat sacalien pada deanja pounja Mousappa samoa sama, lagi saorang pada dia kendiri, djandji lagi basompa macca diaor: mengaco orang besar besar itou, jang pagang segalla negri Hollande pounja houcom lagi prince Orange menjadi diaorang lagi tjoutsjounja pounja tuan lagi capella, jangan boat barang boudi attau mosselehat padanja, tatapi lalaijani padanja baibaic, begitou lagi pada Gouvernador jang ganti pada Guael desini, lagi tinghal sacaran desini de tanna Bandan, attau capalla lain jang jadi tarou deri gouvernador iton, attau ganti dia, lagi tourut samoa jang diaor: souro menouro.

Orang caija caija lagi capalla samoa de Poulou-run bri dalam tangan Generael tanna Poulou run dengan cottanja sacalien, lagi segalla boanja, septi orang Selammon, Waijar, Oundinner, Comber daen Rossangijn souda boat daulou. Macca itou jadi songho songho, boucan dengan barang mosselehat, lagi barang orang lain tida bole minta satou satou deri negri itou, hanja boucan diaor: djandji itou

\footnotetext{
1 Siapa.

2 Diaorang.
} 
pada diaorang kendiri, tatapi lagi pada diaor: pounja tjoutsjou, begitou seperti diaorang bri songho songho, lagi dengan hati tjoutsji negri ini padanja, dengan sourat ini, macca begitou diaorang tida kenal barang orang lain menjadi capalanja attau tuanja jang hala], melaincan orang besar besar jang pagang Hollande pounja houcom, attau orang itou jang souda tarou desini berganti deanja.

Agar caliattan baibaic macca diaor: kenal tuanja, diaor: bri pada diaorang deri segalla boanja, jang tanna Poulou-run bri, deri sapoulou satou.

Diaor: bava bonga palla samua de Nera ca de Poulou Aij aken djuwal pada nang sjappa souda jadi tarou desanna deri pada Gouvernador memblican: hanja jangan diaor: bava boa jang tida baic, lagi jangan diaor: djuwal acan pada orang lain.

Diaorang tida bole boat barang cotta lagi, hanja doudoc de bava de panja 1 jouga. Djicalou Gouvernador de Bandan tsjinta barang toulong de prang pon baic, boat cotta pon baic de negri Bandan ini, diaorang bangat toulong padanja, lagi tourut dia pounja prenta, begitou jouga septi diaor: dapat lagi septi souda jadi cassie padanja.

Diaorang tide bole boat barang houcom kendiri, hanja manacalla satou satou jadi tsjidera, diaorang minta houcom pada Gouvernador, jang comedien bitsjara dengan orang caija caija deri poulou itou, lagi demikien diaorang houcom segalla barang barang.

Diaorang lagi djandji daen basompa macca diaor: mau boat samoa paracarra capada tuanja, septi patout pada raijat jang baic lagi adil, tourut baibau (jangan nacalboudi) pada dia pounja prenta attau sabda deri orang itou jang souda jadi tarou berganti diaorang.

Samoa itou orang caya caija lagi capalla de negri djandji lagi basompa, boucan jouga pada diaorang kendiri hanja lagi diaor: mau toulong macca orang lain pon boat begitou, lagi pon toulong pada Gouveruador berhoucom pada jang sjappa tida mau tourut samoa itou.

Agar catouwan, ${ }^{2}$ samoa itou orang caija caija lagi capalla sacalien deri negri Poulou-run souda basompa tourut samoa paracarra itou, boucan jouga diaorang kendiri, hanja orang samoa jang doudoc de Poulou-run attau jang comedien datan, doudoc desanna, tagal itou diaorang souda batandacan sourat ini dengan tanganja kendiri.

\footnotetext{
1 Pontjak?
}

2 Ketahoean. 
Souda jadi de cappel Hollandia, jang souda berlabo de Banda, dalam boulan Mey hari jang casembila dalan tauwon 1621 .

Ini sourat segalla orang caija caija Poulo Ay daen Ponlou-run, datang pada Generael jang de paliharacan Allah pada sacalien tampat.

Adapon comedien deri itou, kita sacalien minta pada Generael, aken berboattan jang delapan paracarra itou, suppaija jangan jadi fitena comedien lagi,- carna bawa tella segalla orang caịja sacalien tana Baudan berdjandji dengan Gnael, membriacan tanna Bandan sacalien pada prince Hollande dalam tangan Generael dengan segalla orang caija caija Poulou-run pon demikin lagi membriacan tanna Poulou-run pada prince Hollande dalam tangan Generael jouga. Sebab itoula, macca kita sacalien minta djandji pada Gnael aken berboattan jang dualapan paracarra itou suppaija jangan jadi fitena comedien lagi, suppaya namma (?) tana Bandan itou de pagang ole prince Hollande, sampey dounja binassa jouga, adapon jang pertama kita sacalien minta djandji pada Generael.

Saparacarra agama kita, jangan dia haribiroucanja barang berboattan agamma kita, melaincan kita sacalien doudoc dengan agamma kita, orang Hollande pon doudoc dengan agammanja.

Cadua paracarra jangan haribirou pada anac bini orang.

Catiga paracarra jangan massoc pada rouma orang dengan berboattan djahat.

Ca ampat paracarra jangan memoucol orang dengan tiada salla, djicalou salla orang Bandan, melaincan dengan bitsjara jouga.

Calima paracarra jangan merampas pounja orang dengan tiada souca.

$\mathrm{Ca}$ anam paracarra jangan seassat pada orang dengan barang cardja, carna kita sacalien tida beassa pada berboattan jang demikien itou.

Catoudjou paracarra jangan dibava kita prang pada negri lain, melaincan djica barang adda mouso datan de negri Bandan, macca kita sama samma orang Bandan dengan orang Hollande menlawan mouso itou.

Cadelapan paracarra, djica orang Bandan lari pada orang Hollande, melaincan dia poulangcan jouga, attau orang Hollande lari pada orang Bandan, melaincain dia poulangcan jouga, suppaija jangan jadi fitena comedien lagi, daen jangan jadi bersallahan antara orang Bandan dengan orang Hollande, suppaya sempourna bacardjahan Generael menbaiki tana Bandan, sampey dounja binassa jouga, suppaija mosohour nama Generael pada barang sacalien 
tampat, de bava angin lagi, deatas angin; jangan berouba lagi sampey dounja binassa jouga bacardjahan Generael sacaran. Itoula kita sacalien minta djandji pada Generael, carna berboattan delapan paracarra itou, tiada dapat kita sacalien tanghong padanja, melaincan jadi fitena jouga antara orang Bandan dengan orang Hollande.

Sebab itoula macca kita sacalien membri tau pada Generael dengau hati kita tsjoutsji, carna kita sacalien tella meningar sabda Generael acan sacaran ini ija hendac membaiki tanna Bandan sampey dounja binassa jouga. Adapon sacali cahendac Generael demikien, kita sacalien pon hendac saribou scali dengan souca, septi cahendac Generael lagi; sebab itoula macca kita minta djandji pada Generael aken berboattan jang delapan paracarra itou, jangan mengardjacan dia, suppaija sempourna bacardjan Generael sampeij cadengaran pada sacalien alam aken adil nama Generael, suppaija barang negri icot cattanja. Itoupon kiranja Generael tella souda mengatauwi, tatapi sebab kita dengan hati tsjoutsji, macca kita sacalien membri ingat pada Generael jouga, carna bahouwa kita sacalien manusia ini adda jouga loepa, melaincan Allah ta allah jouga tida loupa. Itoupon manna lebi bitsjara Generael jouga deripada kita sacalien, saribouscali souca pada bacardjahan Generael, sacaran hendac baiki tanna Bandan, sebab itoula macca kita sacalien bri tau pada Generael dengan hati kita sacalien tsjoutsji, macca kita minta pada Generael aken berboatan jang delapan paracarra itou, suppaija cacal bacardjahan Generael lama lammanja sampey dounja binassa jouga.

Adapon djicalou Generael trima pada mintahan kita sacalien pada berboatan delapan paracarra itoe, kita sacalien minta sourat pada Generael, suppaija kita sacalien pagang, tacot Generael poulang, calou datang Generael jang lain lagi, suppaija jangan melalouwi prenta Generael, tacot jadi fitena lagi, sebab itoula macca kita sacalien minta djandji pada Generael, suppaija jangan jadi bersallahan lagi, itou pon melaincan manna lebi bitsjara Generael jouga, acan membaiki tanna Bandan, carna houcom tanna Bandan itou sacarang dalam tangan Generael souda, melaincan atas prenta Generael jouga, macca souda Gnael trima djandji orang caija caija Poulon Ay daen Poulou-Run aken berboattan delapan paracarra itou, tiada dapat orang lain berouba pada prenta Gnael lagi. Souda jadi dalam cappel Hollandia dalam boulan Meij, hari nang casembilan, dalam tauwon 1621 .

Adapon jang djandji delapan paracarra itou souda Generael bri, dengan djandji baibaic pada orang caya caya sacalien Poulou-Ay 
daen Poulou Run, tiada dapat orang lain berouba lagi, barang Gouvernador jang deri Bandan attan Gouvernador jang lain tourut jouga septi djandji Generael pada berboattan delapan paracarra itou, tiada dapat orang lain mengardjacan bacardjahan itoe lagi, carna Generael souda bri djandji dengan segalla orang caija caija PoulouAij daen Poulou-Run.

\section{J. P. Coen.}

\section{AMBON.}

\section{Juni 1621. 1}

De gouverneur Van Speult had geen gemakkelijke taak op de Ambongroep. Niet alleen, dat het gezag der Compagnie en haar handelsstaatkunde - die de Amboneezen uitsluiten wilde van de commercie met andere vreemdelingen, b.v. met de Engelschen - steeds meer ontevredenheid teweeg brachten onder de inheemsche bewoners dier eilanden; maar ook (en niet het minst) werkte de houding der Ternatanen mede, om de toestanden minder bevredigend te doen zijn. De sultan van Ternate en zijne vertegenwoordigers op de Ambon-eilanden begrepen zeer goed, dat de meerdere machts- en invloedsontwikkeling der Nederlanders dáár te hunnen nadeele moest komen en betwistten o. a. de rechten der O. I. C. op sommige dorpen. Vooral Hidajat of Daja - een aanzienlijk Ternataan ${ }^{2}-$ is in de jaren van Van Speult de leider der anti-Nederlandsche elementen. Ook het optreden van den Nederlandschen gouverneur tegen den Islam werkte in de richting van vijandschap en zelfs de kapitein Hitoe werd hierdoor onvriendelijker gestemd.

Toen nu minder gunstige berichten over de positie der Nederlanders te Djakatra Ambon bereikten en daarmede de hoop op tusschenkomst der Engelschen mêe sprak, nam de onrust grooter en ernstiger verhoudingen aan. De wapenen deden zich alweer spoedig gelden. Een kentering kwam natuurlijk weder na de verovering door ons van Djakatra en het terugtrekken, voor het oogenblik, van de Engelschen. Toen nu Coen, na zijn optreden op de Banda-eilanden, in Mei 1621 op Ambon kwam, kon hij daar gemakkelijk de leiders naar zijn zin zetten en hunne meer of minder ondergeschikte verhouding tot de Compagnie door hen doen bekennen en bevestigen. (Vgl. hiervóór verschillende contracten met de Ambon-eilanden.) Dit gebeurde in eenige bijeenkomsten in het kasteel Vietoria van 1-7 Juni 1621, onder leiding van den Gouverneur-Generaal gehouden. (Vgl. Tiele, Europeërs, IX, bldz. 262-268; Bouwstoffen, I,

1 Overgenomen uit Valentijn, II, b, blz. 50, v.

${ }^{2} \mathrm{Hij}$ werd de opvolger van Sabadin (die in 1619 overleed) als stadhouder van Klein-Ceram. (Vgl. hiervóór, bldz. 142, noot 6; Tiele, Europeërs, IX, bldz. 264; Tiele, Bouwstoffen, I, bldz. XLVII, 264, 269, 295, v. enz.). Reeds vóór Sabadins dood nam hij op de Ambon-eilanden een plaats in de verhoudingen in, niet zonder beteekenis. (Bouwstoffen, I, 226, enz.) 
bldz. XLVII, 294-297; Valentijn, II, b, bldz. 45-51). Het resultaat der besprekingen is nêergelegd in onderstaande hoogstbelangrijke akte, welke (in verband met die besprekingen) doet zien den omvang van het Nederlandsch gezag in die streken ' ${ }^{\prime}$ in 1621.

De Ed: Heer Jan Pieterssoon Coen, Gouverneur-Generaal, van wegen de Ed: hoog Mogende Heeren Staten Generaal, zyn Excellentie, Mauritius, Prince van Orangie, Grave van Nassau enz., de Heeren Bewindhebberen der Generale Compagnie van de Vereenigde Nederlanden in Indien, zeer genegen zynde omme de inwoonderen harer onderdanen van de landen, eilanden, steden ende plaatsen in 't lant van Amboina, ende daar omtrent gelegen, in ruste, vrede, ende eenigheit te houden, ende alle misverstanden, zoo veel mogelyk is, te weeren, ende te ondertasten, van waar die haren oorspronk nemen, zoo heeft zyu Ed: aan Harman van Speult, zynen Luitenant Gouverneur, belast, alle de onderzaten, bondgenoten ende nabuerige vrinden, te beroepen, waar op de hier voorgenoemde Koningen, hoofden ende principalen ${ }^{2}$, zyn gecompareerd, die ter presentie van den bovengemelden Heere Gouverneur Generaal, de Ed: Heer Frederik Houtman, Harman van Speult, Willem van Witsen, ende ondergeschreven getuigen, ider in 't bezonder hebben verklaard, beloofd ende gezwooren, gelyk zy verklaren, beloven ende zweeren by dezen solemnelen eede, aan handen van den Ed: Heer Generaal, en de presente

1 Niet verschenen op die vergaderingen: Amahei, Makariki, Sooehoekoe, Sepa, Tamilaoe, Toeloeti (alle dorpen op Cerams Zuidkust), Boeroe, Amblaoe, Lisabata (op de Noordwestkust van Ceram), Boano en Kelang.

? Volgens Valentijn, die blijkbaar het Ambonsche archief hier heeft geraadpleegd, waren dit de volgende inlandsche hoofden. De kapitein en de orangkaja's van Hitoe (30 negerijen), de radja van Noesaniwe (7 negerijen), het (gewezen) hoofd van Hoetoemoeri, radja Kilang (3 neg.), radja Soja (3 neg.), het hoofd van Ema (3 neg.), het hoofd van Halong, dat van Hatiweh (3 neg.), van Wai, Alang, Liliboi, de orangkaja's van Lariki, van Oering en Asiloeloe, het hoofd van Bagoeala enz., allen op Lei-Timor, en langs de Zuid-West- en Noordkusten van Hitoe. Verder de radja's van Oelat (4 neg.), van Toehaha, van Paperoe, de hoofden van Haria, van Boi, van Tiow, van Sirisori, van Thamahoe (Iha en Maoe, 8 neg.), allen op Saparoea. Van het eiland Haroekoe: de hoofden, onder verschillende benamingen, van Oma, Aboro, Haroekoe, Samet, Karioe, Hatoeaha (4 neg.). Van het eiland Noesalaoet: de hoofden van Titawai, Lenitoe, Aboeboe, Sila, Amet, Akoon, Nalahia. Op de Zuidkust van Ceram: de hoofden van Kamarian, Seroeawan, Roemakai, Titoelale, Latoe en Haewoeri (5 neg.) en „de hoofden van Elipapoeteh": een onnauwkeurige omschrijving. Verder in West-Cerams binnenland verschillende Alfoersche „koningen", enz., o. a. van Sahoelau, Soemait, Wasia (ruim 30 negerijen). - Over Manipa, zie beneden n ${ }^{\circ}$ LXXIV. 
Raaden gedaan, de bovengemelte Hoog Mogende Heeren Staaten Generaal, zijn Excellentie Mauritius, Prince van Orangie, Grave van Nassau enz., de Heeren Bewindhebberen, ende hare gesubstitueerden, tegenwoordige, ende toekomende, voor hare Souveraine Heeren te erkennen, gehoorzamen, gehouw ende getrouw te zyn, ende te assisteeren, tegen alle vyanden, zoo wel te water als te land, als getrouwe onderdanen toestaat te doen, gelyk zy voor deezen belooft, en gezworen hebben.

Actum in 't Kasteel in Amboina dezen 7 Juni A. 1621, was getekent J. P. Coen, Fredrik Houtman, Harman van Speult, Willem van Witsen, P. Pietersz. Wagensveld, Cornelis van den Berg, Cornelis de Meyer, Daniel du Buquoy, Laurens de Maarschalk, 't merk van ${ }^{1}$ Jan Cornelisz, Luitenant, J. van Breul, Maarten Jansz. Visscher, 't merk van ${ }^{2}$ Charles Houw, vendrig, Jan Graswinkel, Hendrik Lievensz., Christoffel van der Gracht, Jozephus Mostaard, Georgius Musschamp, Henri Woolman, Simon Colin, Mathieu de Klerk, Hans Jansz., dit merk van Gerrit Gerritsz. Bak. ${ }^{3}$

LXXII. JAPAN.

1621. 4

De vijandelijkheden, tusschen Nederlandsche en Portugeesche schepen in de zeeën van Japan bedreven, welke den toenmaligen handel der Portugeezen op Japan af breuk deden, hadden reeds sedert eenige jaren de Japansche autoriteiten ontstemd. Erger werd dit nog, doordat ook Chineesche vaartuigen door de onzen werden aangeklampt, toen aan de Nederlanders niet grifweg de handel op Chineesche havens werd ingeruimd. Na het verdrag van 1619 tusschen de Nederlandsche en

${ }^{1}$ Hier staat bij Valentijn een A, die niet tot den naam behoort blijkbaar. - Opmerkelijk is het wel, dat drie der Nederlandsche onderteekenaars hunnen naam niet konden schrijven.

" Hierbij de letters „C. V. A. O."

3 Deze akte is onderteekend, behalve door den Raad van 't kasteel Victoria, ook door den Raad, welken Coen had mêegebracht. De leden staan door elkaar naar hunnen rang.

Sommige namen zijn door Valentijn verkeerd gespeld: ik vond echter niet noodig, op deze schrijffouten afzonderlijk opmerkzaam te maken.

4 Overgenomen uit Valentijn, V, 2, b (Japan), bldz. 30, v.

De datum dezer bepalingen staat niet vast: zij komen voor in een brief van Specx van 20 September 1621 en schijnen niet lang te voren te zijn uitgevaardigd. 
Engelsche Oost-Indische Compagnieën, toen de verhouding tusschen Engeland en Nederland in het Oosten voor het oogenblik aanmerkelijk verbeterd werd en de Engelschen met de Nederlanders gezamenlijk óók in Oost-Azië optraden, nam de Japansche regeering een ernstiger toon dan vroeger aan. Vandaar onderstaande bepalingen. (Nachod, Japan, S. 169-176; Lauts, Japan, bldz. 179-184; Tiele, Bouwstoffen, I, bldz. 75, $177,178,182)$.

Werd verboden geen Japansche natie, gehuurd, ofte gekogt, zonder pas van de Majesteit, met onze, of de Engelsche ${ }^{1}$ schepen, of jonken uit te voeren. ${ }^{2}$

Geen korte sabels, korte of geen andere geweeren, ende oorlogsmaterialen ${ }^{3}$, zullen mogen uitgevoerd werden.

De Hollanders, ofte Engelschen, zullen omtrent Japan op zee niet rooven. ${ }^{4}$

Tot Nangasacki zullen, zoo die van 't groot schip, 5 als andere schepen van buiten 's lands, hun handeling doen conform de ordre, die by tyden van Ongosiosama daar in gesteld is, zonder iets te veranderen. ${ }^{6}$

Op 't schip, dat van de kooplieden in Nangasacki by de Hollanders, ende Engelschen in zee geroofd is, onderzocht zynde, zeggen, dat

1 Dat de Nederlanders en Engelschen in deze bepalingen steeds naast elkander worden genoemd, wordt natuurlijk verklaard door hunne onderlinge verhouding na het verdrag van 1619 .

${ }^{2}$ Het blijkt uit de aanteekeningen, door Specx gemaakt bij deze bepalingen, dat dit artikel verband houdt met het gebruiken in onzen militairen dienst van Japanners. Het is bekend, dat de O.I. C. vele Japanners in dienst had. (Vgl. Nachod, t.a.p., S. 157; Valentijn, t. a. p., blz. 30; Tiele, Bouwstoffen, I, 365, sub voce: Japanners in Nederl. dienst).

Het onderscheid, hier gemaakt, tusschen gehuurd en gekocht, is mij in dit verband niet duidelijk.

De dapperheid der Japansche soldaten werd door de onzen over 't geheel zeer geroemd.

3 Specx vindt in dit verbod van uitvoer van wapenen weinig bezwaar voor de O. I. C., indien ten minste onder oorlogsmaterialen niet ook koper en ijzer bedoeld worden.

4 Specx meent, dat de Japanners niet voldoende kennen het onderscheid tusschen zeeroof en het aanslaan van 's vijands schepen.

${ }^{5}$ Vermoedelijk wordt hiermede bedoeld het groote Portugeesche handelsschip, dat jaarlijks van Macao naar Nangasaki voer. (Nachod, t. a. p., S. 40).

"Specx ziet hierin voor ons geen bezwaar. De Portugeezen "en andere vreemde scheepen, tot Nangasacki komende", hebben blijkbaar meerdere vrijheden in den handel verzocht. Dit is hun dan echter geweigerd en deze weigering is tegelijk tot andere vreemdelingen uitgestrekt. Maar wij blijven in dezelfde conditie als voorheen, onder de bepalingen n.l. van Ongosiosamma (Iyeyasoe). Vgl. hiervóór, $\mathrm{n}^{\circ} \mathrm{XL}$. 
daar twee Paapen ' in geweest zijn, ende daarom 't zelve genomen hebben. Of 'er Paapen zyn, zult [gij] ${ }^{2}$ naauw onderzoek doen, ende hen laten weeten.

\section{DJAMBI.}

25 October 1621. ${ }^{3}$

Niettegenstaande het accoord van 24 Juli 1620 , bleef de verhouding tusschen de vertegenwoordigers te Djambi der Nederlandsche en Engelsche Compagnieën op het stuk van den handel te wenschen over laten. (Onuitgegeven missice van Pieter de Carpentier, directeur-generaal, aan de Bewindhebbers, 9 Juli 1621.) Een nieuwe overeenkomst bleek noodig.

Articulen geraemt ende geaccordeert tusschen de gedeputeerde van de Engellsche ende Nederlandersche Comp ${ }^{e}$ in Jamby, zoo om den peper tot lager prijs te brengen, als ook om voor te koomen ende aff te weeren alle confusie ende misverstanden, die te weder zyde zouden mogen komen te rijzen.

Ten eersten dat van nu voortaen van wederzijde van geenige persoonen de peper hooger zullen koopen als $7 \frac{1}{2}$ Rs 't picoll 4 , uytgesondert 12 persoonen, wesende de principaellste coopluijden deser stede, die men geven ende betallen sal a $7 \frac{3}{4} \mathrm{Rx}^{\mathrm{s}}$ 't $\mathrm{p}^{1}$, allsoo het voorkoop $^{\mathrm{rs}}$ zijn; ende dat dese resolutie niet sall verandert worden van ymant int particulier, maer staen tot breeder ende naeder resolutie van de voornoemde gedeputeerde van beyde de Comp ${ }^{\mathrm{e}}$. De namen van de 12 voornoemde koopl $^{\mathrm{n}}$ staan in margine als te sien is. ${ }^{5}$

Ten tweede dat alle oude uytstaende schullden, zoo die voort' accoord van d' $\mathrm{E}$. $\mathrm{H}^{\text {ren }}$ raden van $\mathrm{B}^{{ }^{6}}$ uijtstonden, als anders, dat die van nu voortaen niet meer zullen in rekeningh gebraght offte van gesprooken

1 Zooals bekend, waren de Christenvervolgingen in Japan reeds begonnen. (Vgl. Nachod, t. a. p., S. 62ff, 161ff.)

2 Nl. de vorst (daimyo) van Hirado, die deze bepalingen ter mededeeling aan de Nederlanders had ontvangen van het toen krachtige centrale Japansche bestuur. - De groote macht der verschillende grootere of kleinere leenvorsten (daimyo) was vooral sedert Iyeyasoe's optreden aanmerkelijk verminderd ten bate van de macht des Shogoens. (Vgl. Nachod, t. a. p., S. 123).

3 Uit het Contractboek.

$4 \mathrm{Bij}$ de vorige overeenkomst (zie hiervóór, bldz. 157) was dit bepaald op. 8 realen als maximum.

${ }^{5}$ Ik laat deze namen zonder beteekenis weg.

6 Batavia. 
worden ende dat alle peper, die naer dato deses te wederzijden ontfangen zall worden, egalijck gedeellt ende elcx sijn portie sall gegeven worden, volgens 't voorn ${ }^{\mathrm{d}}$ accoordt van de Raedt van defensie. ${ }^{1}$ Ymandt van beijde de Comp ${ }^{e}$ hebbende meer peper ontfangen als de anderen, zall den geenen, die de minste parthye heefft, met reght ende zonder tegen seggen van d'ander mogen eyschen t'eeniger tijt de helffte van de $\mathrm{pp}^{\mathrm{r}}$, die den anderen meer zoude mogen ontfangen hebben, mits gevende datelijck contant gellt oft kleeden in betalingh, zonder eenigh tegenseggen offte uijtstell te wederzijde, zoo van de nieuwe als uijtstaende schulden, hoedanigh die soude mogen wesen.

Ten derde dat nae dato deses eenige prauwen met $\mathrm{pp}^{\mathrm{r}}$ van 0ulou ${ }^{2}$ affkomende ende de persoonen, die se toekompt, schulldigh zijn aen beyde de Comp ${ }^{\mathrm{e}}$, dat de dienaren vau beyde de compagnien de peper haer niet met gewellt offte force, gelijck voor desen geschiet is, d'een tegen den anderen affnemende, om elcx voor syn particulier zyn schullden eerst in te krygen, maer dat zulcke debiteuren, haer peper affkomende, zall gelykelijck gedeellt worden pro rato van haer schullt, nae deselve bevonden zall worden veell off weynigh te wesen, well verstaende, dat niemandt zall mogen spreken offte peper aen slaen, voor en all eer de schulld ${ }^{\mathrm{r}}$ verschenen is.

In kennisse ende tot bevestigingh dese onse resolutie, hebben wij, de gedeputeerde van beyde de Comp ${ }^{\mathrm{e}}$, hier aff twee alleensluydende resolutien laten schrijven ende geteekent den $25^{\mathrm{e}} 8$ ber a ${ }^{\circ} 1621$ stilo novo, in Jambij.

\section{AMBON.}

1 5e Februari 1622. ${ }^{3}$

Ook op Manipa werd tengevolge van het optreden van Van Speult tegenover Hidajat de invloed der Compagnie sterker en in Februari 1622 werd onderstaand contract gesloten. (Vgl. Tiele, Europeërs, IX, bldz. 269, v. - Bouwstoffen, I, bldz. XLVIII, 271, 317-321.)

Alsoo wij ondergeschreven, hoofden, en Orang Kaja's van 't eiland, ende de negoryen van Manipa, in Junio

\footnotetext{
1 Zooals bekend is, waren de gemeenschappelijke belangen der Nederlanders en Engelschen toevertrouwd aan den z.g. Raad van Defensie, bestaande uit vier Nederlanders en vier Engelschen.

2 Vermoedelijk worden hiermede bedoeld de bovenstreken der Djambi rivier (Batang Hari), Oeloe-Djambi.

3 Overgenomen uit Valentijn, II, b, bldz. 53, v.
} 
laestleden door de Orang Kaja's Lessebessi, en Walkoeko, onze gedeputeerden, ons hebben begeven onder de gehoorzaamheid van de Ed. Hoog Mogende Heeren Staten, den Prince van Orangie, de Heeren Bewindhebberen, ende hare Gouverneurs alhier, en dat ten aanzien van den contiuueelen overlast zoo ons, onze geassocieerde vrienden, te weeten die van Lessidi, Cambello en Loehoe, zyn doende, nu onlangs zijn geconstringeerd geweest onze toevlucht te nemen tot de bovengemelde Heeren, om haren Gouverneur van Amboina assistentie en hulpe te verzoeken jegens Kimelaha Daja, Gouverneur wegens den Konink van Ternate, die tegenwoordig op 't eiland Manipa aan de Oostsyde legt, met een armade van 20 a 25 corcorren, om haar land af te lopen, en dat overmits de voorzeide Orang Kaja's haar onder de bovengemelde Heeren hadden begeven, waar over den Gouverneur van Speult, ten aanzien van haar ernstelyk verzoek, zig verpligt vindende volgens belofte van de Heeren Generaal en Raaden van India; haar in haren nood daar tegens te assisteeren met het jagt Pera, de kaag Geldria, en een chaloep, de welke, verstaan hebbende, dat onder de hoofden van voorsz. negrys eenig verschil was, heeft geraden gevonden alle de ondergeschreven Orang Kaja's van Manipa te beroepen, ende den eed van getrouwe onderdauigheit, die zij voor dezen door hare gedeputeerden gedaan hadden aan den Ed: Heere Generael Coen, perzoonlyk in den bovengemelden Gouverneurs presentie souden vernieuwen, het welken zy op haarvolgende conditien by hare Moshhaf, of Wet-boek hebben bezwooren.

Eerstelyk, dat zy de bovengemelte Heeren, ende niemand anders voor hare Souveraine overigheid aanneemen, willen erkennen, gehoorzamen en respecteren, hun jegens alle vyanden, zoo te water als te lande, willen assisteeren als getrouwe en gehoorzame onderdanen schuldig zyn te doen, hem nu nog tot geenigen tyden te verlaten.

Ten tweden, beloven de bovengemelde Orang Kaja's, in gevalle den dienst van de bovengemelde Heeren vereischt, eenige brieven aan 't Kasteel, ofte andere bygelegene plaatzen te zenden, dat zij die zonder eenig loon zullen bestellen.

Ten derden, zoo belooven zy, zoo de bovengemelde Gouverneur 
geraden vond, aldaar een fort, of steenen Logie te maken, dat zy alle materialen, zoo van kalk, steen, hout, en arbeit daar toe zouden fourneeren zonder eenig loon.

Ten vierden, prezenteren de voorsz. Orang Kaja's den bovengemelden Heeren hare Souverainen te geven zoodanigen tol, ofte erkentenisse, als zy onder den anderen, naar vermogen en reden zullen bevinden te bestaan.

Hier en tegen heeft de Gouverneur van Speult, wegens de voorz. Heeren haar beloofd, en gezworen 't naarvolgende te houden, en naar te komen.

Eerstelyk, dat wy haar zullen defendeeren en beschermen jegens alle yyanden, die haar zouden willen overlast doen, naar ons vermogen.

Ten tweeden, dat men haar in hun geloove geen geweld, nog overlast en zal doen, of dwingen haar geloove te verlaten, dan dat zulx aan haar zal staan daar by te blyven, of 't zelve af te staan, waar in ider van haar syn eigen vrye wille zal hebben.

Ten derden, dat men niet en zal gedogen, dat hare vrouwen of kinderen door de onzen eenig overlast ofte outrage zoude geschieden, zonder behoorlyk regt.

Ten vierden, dat men haar hunne nagelen zal betalen ten pryze als men die van Loehoe, Hitoe en Cambello doet, en tot gelyke prys de kleeden zal verkoopen, nog minder, nog meerder.

Ten besluite, om dat alle de bovengenoemde artikelen van wederzyde volkomen onverbrekelyke zoude agtervolgd, ende naergekomen werden, zoo hebben het zelven in kennisse der waarheid met hun eigen handen onderteikent. Aldus gedaan, en gearresteerd, op 't eiland Manipa, in de negry van Toeban ${ }^{1}$, dezen 15 Februari 1622.

\section{V. AMBON.}

14 Januari 1623. ${ }^{2}$

Oók Lesidi (op de Westkust van Klein-Ceram) begaf zich „vrijwillich onder onse gehoorsaemheyt", al zou deze houding niet van langen duur zijn. (Tiele, Bouwstoffen, I, bldz. 333.)

1 Aan de Zuidwestkust van Manipa.

2 Overgenomen uit Valentijn, II, b, bldz. 51, v.

$7^{\circ}$ Volgr. III. 
Alzoo de ondergeschreven Orang Kaja's van Lessidi, als maght en authorisatie hebbende van Latoe Colli ', hier aan 't Kasteel van Amboina haar hebben verkogt ${ }^{2}$, van wegen Latoe Colli en haar ouderdanen, en bekennen vrijwillig verkogt ${ }^{2}$ te hebben, hen op naarvolgende conditien onder de gehoorzaamheit van de Ed: HoogMogende Heeren Staaten Generaal, zyn Princelyke Excellentie, en de heeren Bewindhebberen te willen begeven, dat haar niet en hebben konnen weigeren.

Eerstelyk, is de conditie, dat men haar luiden in haar geloove ongemolesteerd zal laten, ende niemand moeyelyk en zal vallen, dan by zoo verre iemand uit zig zelven versochte Christen te worden, daar tegen en zullen zy luiden niet hebben te zeggen.

Ten anderen, beloven en zweeren de bovengemelde Orang Kaja's uit de name, en als magt hebbende van wegens Lato Colli, en zyne onderdanen, op hare wetboeken, en by God, de hooggemelde Heeren Staaten, zyn Princelyke Excellentie, de Heeren Bewindhebberen, ofte hare Gouverneurs, jegenwoordig, ofte toekomende, in alles gehouw en getrouw te zyn, en te blyven, en jegens alle vyanden, zoo te water als te lande, gelyk getrouwe onderdanen betaamd, te assisteren.

Ten derden, beloven de bovengemelde Orang Kaja's, uit den name van hare superiores, van $\mathrm{nu}$ af aan met niemand eenige pitsjaringe ${ }^{3}$ meer te houden, als met voorweten van den Gouverneur voornoemd, nog veel min met imand anders te roejen ${ }^{4}$, als met de hooggemelde Heeren hare Gouverneurs.

Daar en tegen beloofd en zweerd de Heer Gouverneur van Speult, wegens de Hoog Mogende Heeren Staaten Generaal, zyn Princelyke Excellentie, en de Ed. Heeren Bewindhebberen over de eilanden van Amboina, haar in hare geregtigheid voor te staan, en jegens allen

1 Vermoedelijk heb ik mij vergist op bldz. 143 hiervóór, noot 4. - Uit bldz. 265, deel I, van Tiele's Bouwstoffen, blijkt, dat hij was „de oudste van de Olysivas", terwijl zoowel uit ons Contract als uit een ms. Missive van den bekenden gouverneur van Ambon Artus Gysels, van 10 September 1632 blijkt, dat hij hoofd was van Lesidi.

${ }^{2}$ Zal moeten worden gelezen: "versogt" (of "vervoegt").

$s$ Bitjara = beraad, beraadslaging. - Natuurlijk om te voorkomen verderen invloed der Ternatanen, tot het gebied van wier sultan Lesidi inderdaad behoorde. (Vgl. o. a. Tiele, Bouwstoffen, I, bldz. 320.)

4 Een van de dienstprestaties, waartoe Ternatanen, Portugeezen en Nederlanders de bewoners der Ambonsche negerijen verplichtten. 
overlast te beschermen, en te bevryden, als een goed en getrouw hoofd betaamt ende schuldig is te doen.

Ten vyfden, beloven de Orang Kaja's, de nagelen aan niemand anders, ofte geene andere natien ter wereld, te verkoopen, ofte te leveren, als aan de bovengemelde Heeren haren gecommitteerden, gelyk voor dezen geschied is, op poene, dat men de genen, die daar op [schuldig?] zullen bevonden worden, capitalyk aan den lyve zal straffen.

Alle welke bovengemelde artikelen de Gouverneur bij eede heeft bezworen, voor zoo veel hem betreft, te zullen naarkomen, en aan de andere zyde, beloven en zweren de ondergemelde Orang Kaja's op hare wet alles, wat hier boven gementioneerd is, onverbrekelyk naar te komen, en te doen agtervolgen. In kennisse der waarheit is deze acte van beide de partyen onderteekend buiten arg, list ofte bedrog, ten overstaan van de Koningen van Kilang, Soya, de hoofden en Orang Kaja's van Halong, Hative, Tawiri ${ }^{1}$, en Mardika. ${ }^{2}$

Actum in 't Kasteel Amboina dezen 14 Januari A. 1623, was getekend Herman van Speult, Isaac de Bruin, Laurens de Maarschalk, Lebe Sabtoe, Orang Kay Toeha Picoe, 't merk van Orang Kay Loekoli, 't merk van Manuel Radja Kilang, Laurens de Silva, Radja Soya, 't merk van Diego, Pati Halong, Manuel Castanja, 't merk van Don Pedro, Paulo Gomes, 't merk van Antoni Tawiri.

\section{BANDA.}

26 Mei $1623 .^{3}$

De - althans gedeeltelijk - aan de Portugeezen reeds vóór de komst der onzen in het Oosten bekende eilanden-groepen ten Zuidwesten van Nieuw-Guinea, hadden al spoedig de aandacht der Nederlanders getrokken (in 1605 of 1606 waren zij door het Duif ken onder Willem Janszoon aangedaan), en reeds in het eerste kwart der $17^{\text {de }}$ eeuw werd de mogelijkheid overwogen, deze zoo dicht bij Banda gelegen streken onder

1 Al deze plaatsen liggen op Lei-Timor, in de buurt van 't kasteel Victoria.

2 De z.g. Kampong Mardika bevond zich in de buurt van het Kasteel en bestond, uit vreemdelingen, met de Portugeesen eerst uit de Molluccos hier gekomen, en van hen gebruikt, om zig met deze lieden tegen de Amboineesen te versterken". (Valentijn, II, bldz. 123, b, bldz. 16.)

-3 Overgenomen uit Van Dijk, Carpentaria, b, bldz. 57 vv.

Ik plaats dit en het volgende document onder Banda, omdat in 's Compagnie's tijd de betrekkingen met de Aroe- en Kei-eilanden onder het beleid stonden van den gouverneur van Banda. 
ons gezag of invloed te brengen. Dit gebeurde in 1623 op den beroemden ontdekkingstocht van de Pera en de Arnhem onder bevel van Jan Carstenszoon (Carstensz), enz. Uitdrukkelijk was een der doeleinden van die reis, „om met die van Queij, Aroe en Tenimber vriendschap te maken", terwijl aan de scheepshoofden werd gelast, „met alle coninghen, ende volckeren, die [zij zouden] mogten bejegenen, in vriendschap ende verbont [te] sien te treden, ende haer pogen te trecken onder de protectie van de Staten der Vereenigde Nederlanden". (Vgl. Heeres, Australië, bldz. $21,2 \dot{2} \mathrm{j}^{\circ} 20$.) Het gelukte Carstensz op zijn terugtocht, nadat in Januari en Februari, op de heenreis, de voorbereidende maatregelen reeds waren getroffen, een contract te sluiten met de bewoners van verschillende kampongs der Aroe-eilanden. (Van Dijk, Carpentaria, b, bldz. 5, vv., 50 , vv.)

Jan Carstensoon, Commandeur over de jachten Pera ende Aernem, ende die van sijnen Rade sijn, vuijt last ende commissie van den Ed. Heer Generael Jan Pieterzoon Coen, wegen de Hoog Mog. Heeren Staten Generael, Sijne Ex ${ }^{t i e}$ Prince van Orangien etc ${ }^{\mathrm{a}}$, ende de Heeren Bewinthebberen der Generaele Oostindische Compagnie van de Vereenichde Nederlanden, naar 't eijlandt A ru met voorschr. twee jachten gesonden, omme de orancaijs ende volckeren onder de gehoorsaemheijt van de Hooggemelte Heeren sien te trecken, dat op den $4^{\text {en }}$ Februarius $\mathrm{A}^{\circ} 1623$, Godt sij gedanckt, geschiet is, ende hebben haer alsoo alle de orancais ende volckeren van 't eijlant voorn. goetwillich ende gaerne onder de gehoorsaemheijt ende subjectie van de gemelte heeren overgeven, ende 't landt opgedragen op naervolgende conditiën ende ordonnantiën.

Ten eersten.

Dat d'orancais ende overhooffden van de dorpen Wodgier, Tutewanangh, Salguadingh, Bocan, Guamar, Bagambel, Maịjeoor, Rato, Tarangan ${ }^{1}$ ende meer, sullen belooven ende sweeren, gelijck

1 Uit deze opsomming blijkt, dat met het „eijlandt Aru" wordt bedoeld de eilandengroep. In het journaal van Carstenszoon wordt dan ook in éénzelfde alinea gesproken èn van "t eijlandt Aro" èn van "het noordelijcke" of noordelijkste „eijlandt van Aro". (Van Dijk, Carpentaria, bldz. 4.)

Verschillende dezer in het contract genoemde dorpen zijn zeer goed te recht te brengen. Wodgier is poeloe Oedjir; met Bocan zal bedoeld zijn Wokam; Guamar is poeloe Wamar, terwijl Maikor en Trangan duidelijk zijn te herkennen. (Vgl. voor de plaatsbepaling nog: Heeres, Dortsman, in deze Bijdragen, $6^{\text {de }}$ volgreeks, $I I$, bldz. 87 vv.) 
zij bij deesen vuijten naem ende van weegen de gantsche gemeente, op haer maniere, al t'samen ende elck van hun int besonder belooven, ende sweeren, de Hoog Mo. Heeren Staten Generael, Sijne Ex ${ }^{\text {tie }}$ Prince van Orangie etc ${ }^{\mathrm{a}}$, ende de Heeren Bewindhebberen der Generale Oostindische Comp ${ }^{\text {ie }}$ van de Vereenichde Nederlanden voor hare souveraine ende gebiedende Heeren te erkennen, gehouw ende getrouw te sijn, gelijk mede d'Ed. Heer Generael ende sijne Gouverneurs ofte gesubstitueerde.

2.

Verclaren over sulcx de voorschr. Orancais, dat sij alle hare landen. sterckten, steeden ende vruchten aen de gemelte Heeren suijver ende daerop niemant ijets heeft te pretendeeren, sinseerlijck, sonder arch of list, overgeven en opgedragen hebben, voor haer ende voor hare nacomelingen, gelijck sij deselve landen ter goeder trouwen opdragen ende overgeven midts desen; ende dat geen ander Prins ofte Potentaten, dan alleene de voormelde Heeren sullen kennen voor haere Souveraine ende wettige Heeren.

3.

De orancais ende volckeren hebben als onderdaenen bewillicht ende toegelaten, dat in de wederommereijse op 't voorschr. eijlant int dorp Wodgier een houte columne, door gebreck van steen, opgericht is, daerinne met leesbare letteren 't navolgende in effecte gesneeden staat:

$\mathrm{A}^{\circ} 1623$ den eersten Februarius sijn hier tot Aru aengecommen de jachten Pera ende Aernem, commandeur Jan Carstens, cooplieden Jan Bruwel ende Pr Lintgens, schippers Jan Sluijs ende Dirck Melisz., stuerluijden Arent Martensz. ende Jan Jansz., door ordre ende commissie van den Ed. Heer Generael Jan Pietersz. Coen, wegen de Hoog Mog. Heeren Staten Generael, Sijne Exc ${ }^{\text {tie }}$ Prince van Orangie etc. ende de Heeren Bewinthebberen der Vereenichde Oostindische Comp ${ }^{\text {ie }}$ gesonden, en is bij ons voors. op den 4 Febr. passato possessie van 't eijlandt voor de Hoog gemelte Heeren genomen, ende de orancais ende volckeren onder de gehoorsaemheijt ende subjectie van voorgemelte Heeren begeven ende de prinsen vlagge ontfangen.

4.

De Commandeur ende sijn Raet hebben de voors. onderdaenen belooft ende toegeseijt, gelijck sij belooven ende toeseggen mits deesen 
wt den naem ende van wegen als boven, dat sijluijden met haer vaertuijgh ende coopmanschappen in Amboina ende Banda mogen commen soo vrij ende onbeschadicht als oft sij in haer eijgen landt waren; oock dat haer gevangen, die in voorseijde plaetsen noch in levende sijn, wedergegeven ende restitueert sullen worden.

כ.

De vọors. onderdanen en sullen niet vermogen eenige handelingen met de verdrevene ${ }^{1}$ Bandanesen ofte Cerammers ${ }^{2}$ te doen, ja oock veel min met haer eenige bitchiaringe te houden ende de gevluchte bij haer vuijt het eijlandt te verjagen ende bannen.

De voors. onderdanen sullen oock niet vermogen op eenige andere plaetsen te varen noch te handelen, dan tot Amboina ende Banda, tensij met behoorlijck consent ende passe van de Gouverneurs aldaer.

Aldus gedaen ter preseutie van de ondergenomineerde orancais, int jacht Pera, geanckert onder 't eijlandt Aru, voor 't dorp Wodgier. Adij 26 May A ${ }^{\circ} 1623$.

Jan Carstenzoon.

Jan van Sluịjs.

Arent Martsen de Leeuw.

Pedro Lintges.
Was onderteijckent

Aco.

Levarga.

Bur Belle.

Sulacke.

Queijlabo.

Luberouw.

Terra Terra.

Baran.

Vavoreij.

Ruma Lissy.

Mau Suweij.

Vaij Lieuw.

\section{VII. BANIA.}

\section{1, 3 Juni 1623. ${ }^{3}$}

Ook met enkele dorpen van de Kei-eilanden sloot Carstensz een contract in de eerste dagen van Juni 1623, nadat reeds in Januari voorIoopige

$1 \mathrm{Nl}$. de door ons verdrevene.

2 De van hun land verdreven Bandaneezen zochten vooral hun toevlucht op de Zuid-Oostkust van Ceram en de eilanden ten Zuid-Oosten daarvan.

3 Overgenomen uit Van Dijk, Carpentaria, b, bldz. 55. 
besprekingen met verschillende hoofden waren gehouden. (Van Dijk, Carpentaria, b, bldz. 3, 53, vv.) Deze overeenkomst heb ik niet aangetroffen. Wel blijkt uit Carstensz' journaal, dat deze kampongs na eenige overleggingen zich "eijndelijek als onderdaenen onder de gehoorsaemheijt ende subjectie" van de Staten-Generaal hebben begeven "ende prince vlagge ontfangen". Met toestemming van hoofden en bevolking werd ook hier "een houte columme (bij gebrek aan steen)... opgericht", met onderstaand opschrift :

$\mathrm{A}^{0}$ 1623, den lesten Meij, is hier tot Queij aengecomen 't jacht Pera, commandeur Jan Carstensz., coopman Pieter Lintges, schipper Jan Sluijs, stierman Arend Martensz., door ordre ende commissie van d'Ed. Heer Gener Jan Pietersen Coen, wegen de Ho. Mo. Heeren Staten Generael, Sijne Exc ${ }^{\text {tie }}$ Prince van Orange \&c. ende de Heeren Bewinthebberen der Vereenichde Oostindische Compagnie gesonden, ende is bij ons alsoo op den $3^{\mathrm{n}}$ [Juni] possessie van de dorpen Waijer, ${ }^{1}$ Laer ende Ada voor de Hooge gemelte Heeren genomen ende de orancais ende volckeren onder de gehoorsaemheijt ende subjectie van de voorn. Heeren begeven ende de prince vlagge ontfangen.

\section{VIII. PERZIË.}

\section{November $1623 .^{2}$}

Reeds korte jaren na de oprichting der O. I. C. van 1602 - in elk geval sedert 1609 - werd bij hare leiders, zoowel hier te lande als in Indië, overwogen de mogelijkheid, met Perzië handelsbetrekkingen aan te knoopen, terwijl ook in de Staten-Generaal (o. a. in 1611, in overleg met de O. I. C.) ter sprake kwam de mogelijkheid ,omme in dese landen te brengen voorby de Cabo Bone Spej den handel van de zyde ende ander Persiaensche goederen." (Onuitgegeven resoluties der Staten-Generaal, 1-4 Juli 1611). Eenigen tijd later (ongeveer 1614) werd door Amsterdamsche kooplieden het plan opgevat, langs den weg door Rusland handelsbetrekkingen met Perzië aan te knoopen. (Vgl. Uhlenbeck, Archieven Rusland, bldz. 19). Tot resultaten leidde dit alles nog niet.

In 1620 echter, na den val dus van Djakatra en de stichting van Batavia, werd Pieter van den Broecke, de grondlegger van onzen handel met Arabië (zie hiervóór, No LVII), door den G.G. Coen naar het Westen van Azië gezonden als vertegenwoordiger der Nederlandsche belangen daar, met standplaats Surat. In Januari 1623 zond hij Hubert Visnich met de Heusden o. a. naar Perzië, om te trachten, dáár „den rijeken handel....te stabuleeren." Deze kwam, na o. a. Mocha te hebben

1 "Aen de Westsijde van 't eijlandt." Laer ligt Zuidelijker, volgens het journaal en Ada nòg Zuidelijker.

${ }^{2}$ Uit het Contractboek. - Vgl. hierbij vooral het tractaat met Perzië van 1642 , hierachter opgenomen. 
bezocht, den 20 Juni te Hormus en ging vandaar naar Ispahan, „met een cargasoen van omtrent hondert ende veertich duysent guldens..... om tegen Persische syde te verhandelen." Hij werd door den Sjah zeer aangenaam ontvangen en sloot met hem den 21 November onderstaande overeenkomst, in hoofdzaak overeenkomende met het door Van den Broecke aan Visnich bij diens instructie meegedeelde concept. Inmiddels was de Heusden den 7 October weder te Surat teruggekeerd en den 16 November zond Van den Broecke weder een tweetal schepen naar Perzië „met een deftich cappitael en cargesoen" ( \pm f 150.000). De medegebrachte specerijen en andere handelsartikelen werden "tot goeden prijs aan 's Konings factoor verkocht" en „een goede party zijde" werd "tot redelycken prijs" ingeslagen. De Nederlanders waren in die eerste tijden „zeer aangenaam" bij Vorst en Grooten. (Vgl. onuitgegeven resolutie Heeren XVII Augustus 1617; ms. journaal van Van den Broecke; onuitgegeven instructie voor Visnich, extract-journaal en missive aan G. G. en R. dd. 18 Januari 1624 van Visnich; onuitgegeven missive der Heeren XVII aan G. G. en R. van 17 October 1624; Dagh-Register 1624-1629, bldz. 29).

In het Contractboek bevinden zich bovendien onderstaande documenten, waarvan de Nederlandsche dagteekening waarschijnlijk onjuist is, maar die in elk geval verband houden met Van den Broecke's poging, in den handel van Perzië deel te krijgen.

Translaet van de commandamenten ${ }^{1}$ van den Chan van Sieraes ${ }^{2}$, ons op den $13^{\text {en }} 8^{\text {ber }} 1622^{3}$ verleent.

Aan den daroga ${ }^{4}$ van Laer ${ }^{5}$ ende op de wegens.

Sult weten, alle die onder mijn regeringe eenigh gebiet hebben, op wat plaetse ook soude mogen wesen, ende int bijsonder ghij

${ }^{1}$ Deze bevelschriften van de daarin genoemde autoriteiten zijn blijkbaar ò aan de Nederlanders ter hand gesteld, om daarvan gebruik te maken, òf aan hen medegedeeld. Van dergelijke bevelschriften bevinden zich meer in het Rijksarchief. Ik druk ze alléén af, indien zij bijzonderheden ons leeren, van elders onbekend en voor deze uitgave van beteekenis.

2 De khan (vorst, „hertog" of gouverneur) van Sjiraas (in het Zuidwesten van Perzië) oefende namens den Sjah gezag uit, behalve over Farsistan, ook over Laristan (Vgl. Hobson-Jobson, p. 386) en over het toen pas verworven eilandje Hormus, dat in het begin van 1622 met behulp der Engelschen op de Portugeezen was veroverd, welke dit eertijds zoo belangrijke handelscentrum op den weg van Oost naar West ruim een eeuw in bezit hadden gehad. (Vgl. Birdwood, India Office, p. 168-170, 213; Danvers, Portuguese, II, p. 211,212$)$.

3 Zie over deze vermoedelijk foutieve dagteekening beneden aan het slot van dit "translaet."

4 Met deze benaming worden in Perzië in den loop der tijden verschillende ambtenaren van hoogeren en langeren rang aangeduid: hier beteekent zij blijkbaar een politie-ambtenaar van niet lagen rang, welke ook het toezicht op de wegen uitoefende (Hobson-Jobson, p. 230).

${ }^{5}$ Lar, in het Zuiden van Laristan. 
die reghter in Laer zijt, dat ick Ul. gebiede, dat men de Nederlandsche natie overall faveur en vriendschap sall betoonen en dat niemandt hem sall vervorderen, van de goederen die zijluijden uijt offte inbrengen sullen, de waerde van eenen penninck te eijsschen, nogh ook radarij ${ }^{1}$ offte wie het soude mogen wesen; begeere ook, dat men deselve natie dienstigh zij in alles, dat deselve soude mogen versoeken: in somma dat deselve in alle hun begeeren hun contentement becomen. Sulcx is mijn gebodt en beveelen. Geschreven in de maendt Sadigia $\mathrm{A}^{\circ} 1032^{2}$.

\section{Aan de Sulltan van Ormus ende Gamron. ${ }^{3}$}

Ick die van wege sijn konincklijcke $\mathrm{May}^{\mathrm{t}}$ gebiede, commandere aen UE., die van mijnent wegen gestelt zij, sulltanij (?) en gouvern ${ }^{\mathrm{r}}$ in (?) Ormus en Gamron, op 't hooghste te bewaren de vriendtschap, die wij met de Nederlandsche natie voorgenomen hebben te houden en wanneer eenige haerder schepen costy arriveeren, deselve sult laten anckeren daer 't hunlieden goedt dunckt; begeere ook, dat niemandt van hunne goederen, die uijt offte in voeren sullen, int minste jets sall eijschen, nogh ook die ontfangen 't reght gousij 4 offte radary offte wie het zoude mogen wezen, in somma dat de Nederlandtsche natie in alles gecontenteerdt, ook in alles, dat (zij) op Ul. versoeken promptelijck gedient werden. Begeere dat het voorschreven aghtervolght ende naergekomen worde. Geschreven nell mese ${ }^{5}$ de Sadigia $A^{0} 1032 .{ }^{6}$

1 Rahdari $=$ doorvoerrechten; tollen (Hobson-Jobson, p. 570). Ook rechten, voor de veiligheid der wegen op te brengen.

${ }^{2}$ Zie over deze dagteekening het slot van dit "translaet."

3 Of Bender Abbas aan de Zuidkust van Perzië, ten Noordwesten van het eiland Hormus.

4 Beteekent blijkbaar hetzelfde, als rahdari.

${ }^{5}$ Italiaansch: in de maand.

6 Vermoedelijk een verbastering van Dsûl-hiddscha. Nu begint deze maand van het Mohammedaansche jaar 1032 den 26 September 1623 A. D., terwijl 13 October 1622 zoude vallen in genoemde maand van het Moh. jaar 1031. (Wüstenfeld, Vergleichungs-Tabellen, S. 42 f.) Er is dus een schrijffout ò in de Christelijke ò in de Mohammedaansche tijdrekening. Vermoedelijk in de Christelijke: immers Visnich komt pas in 't midden van 1623 in Perzië. Het zou mogelijk zijn, dat Van den Broecke reeds in 1622 schriftelijke betrekkingen met Perzië had aangeknoopt, waarvan deze aanschrijvingen dan het gevolg zouden hebben kunnen geweest zijn, maar deze oplossing lijkt mij minder aannemelijk dan het aannemen eener vergissing in de Christelijke tijdrekening. Een soortgelijk bevelschrift werd aan den „Sultaan een geweesene Sultaan van Gamron" gezonden „in de maend Zie'l Hizjeh" (of Huzjeh) „des 
Translaet van de capitulatie aen Sijn May van Persia Chia Abas ${ }^{1}$ overgelevert ${ }^{2}$, waervan den jnhouden, als blijckt bij de andwoorde, ons geconsenteert en met sijn ordinary segell bevestight heefft.

\section{1.}

Dat Sijn $\mathrm{May}^{\mathrm{t}}$ den vrijdom geefft aen de Nederlandtsche natie, te mogen comen ende door alle plaetsen, onder Sijn May ${ }^{t}$ gebiet staende, hunne handelinge drijvende, coopen en vercopen alderley coopmanschappen, geene uitgesondert, sulx als deselve natie sall goet duncken hunne negotie vorderlijck te wesen: Consenteerdt 't selve.

2.

Dat de Nederlandtsche natie niet en sullen gehouden wesen, van eenige persoonen wie het ook soude mogen wesen eenige sorteeringe van coopmanschappen over te nemen tegens haren wille, maar dat onbedwongen sullen handelen, coopen ende verkoopen alle immaginabile sorteeringe en coopmanschappen, sonder aensien van eenige persoonen, van wat qualiteijt deselve soude mogen wesen: Consenteert alsvooren.

3.

Dat de Nederlanders niet en sullen hebben te betalen eenigh reght offte thollen op hare inbrengende offte uytvoerende goederen offte comptanten, maer dat alle comptanten en coopmanschappen, die zij inbrengen offte uitvoeren sullen, sall vrij wesen van alle last ende beswaringe, ten ware de kleine geregtigheden der naerders ${ }^{3}$, allsoo van outs in gebruijck geweest is.

Antwoordt: Niet een penninck meer als de costuyme. Sall ook niemandt, van wadt qualiteyt hij soude mogen wesen, vermogen uwe goederen derhallve openen offte op te houden.

4.

Dat geene minissters ${ }^{4}$ sullen vermogen de coopmanschappen offte jaars 1033" (of 1043?), dus tusschen 14 September en 14 October 1624. (Contractboek Amsterdam, III). Hij moest, aan de Nederlanders „alle eer en respect in den uijttersten graadt betonende, sigh van haer gaede te slaan ende waer te nemen niet vrij en houde[n]": zoo luidt het hierin, naast de bepalingen over vrijheid van rechten, enz.

1 Abbas I, de Groote, sjah van Perzië, 1582-1627 of 1628.

? Nl. door de vertegenwoordigers der O. I. C. Het ontwerp van het tractaat was opgesteld door Van den Broecke.

s Rahdars?: tolbeambten op de wegen (Hobson-Jobson, p. 570).

4 Ambtenaren. 
comptanten van de Nederlandsche natie, soo jncomende als uytkomende, op te houden, onder wadt pretext het soude mogen wesen; veell min in eenige tollhuysen te doen brengen, waer ${ }^{1}$ dat Nederlanders sullen mogen met hunne goederen reijsen door alle steden, wegen offte vasste plaetsen, sonder eenigsints van de gouvern ${ }^{\mathrm{r}}$ offte regeerders, daer t' soude mogen wesen, gemolessteert offte opgehouden te worden, veell min visitatie van hare goederen te gedoogen.

Andwoordt: Niemandt sall vermogen uwe goederen, inkomende offte uytgaende, opte houden, ten ware eenige dingen die generallijck verbooden zijn.

\section{5.}

Dat de Nederlandsche natie sullen mogen gebruycken in t' ontfangen ende uijtleveren van hare coopmanschappen allsulke gewight, elle offte mate, als sij op alle plaetsen, daer hunne handelinge soude mogen vallen, daartoe binnen haeren huyse sullen mogen houden, sonder dat 's landts gezette wegers jets daer tegen sullen hebben, veell $\min$ te pretendeeren eenigh reght offte waeg gelt, gelijck d' ondersaten van sijn $\mathrm{May}^{\mathrm{t}}$ schulldigh zijn, ten ware t' ontfangen ende wegen van de zijde offte grote ende merckelijcke perthijen: Wordt geconsenteerdt.

6.

Offte eenigh Nederlander op eenige plaetsen, onder 't gebiedt van Sijn May ${ }^{t}$ sorteerende, quame te overlijden, sonder dat eenigh compagnon offte andere van zijn landtsluyden bij hem hadden, sall de justitie daer ter plaetse gehouden wesen, de goederen bij den overleden bevonden in bewaringe te nemen, tot dat een ander in des overleden plaets sall worden gestellt offte dat van hunne overheden sullen werden gevordert, aen welcke de justitie sall gehouden wesen alles onvermindert weder te leveren. Maer soo ter plaetse, daer eenigh Nederlander quaemen te sterven, meer offte andere persoonen van deselve natie bevonden wierden, sall de justitie int minste niet vermogen de goederen aen te tassten : Wordt geconsenteerdt.

7.

Dat Sijn Konincklijcke May ${ }^{\mathrm{t}}$ van Persia hem verobligeerdt en beloofft te betalen, volldoen en restitueeren alles dat de Neder-

1 Schrijffout voor „maer." Zie Valentijn, V, 1, a, Persien, bldz. 293. De tekst bij Valentijn bevat niet de antwoorden van den Sjah op het ontwerp der Nederlanders. 
landsche natie binnen de jurisdictie van Sijn May $^{t}$ soude mogen werden. ${ }^{1}$

Andwoordt: Den gouvern ${ }^{\mathrm{x}}$ offte sadaer ${ }^{2}$ ter plaetse, daer de goederen gestolen worden, sijn gehouden den voorschreven artykell te volldoen.

8.

Dat de Nederlanders int minste niet en sullen gegraveerdt worden in de bevraghtinge van de camelen, muylen offte draagpaerden, maer alle de muckers ${ }^{3}$ offte carabaen bassis ${ }^{4}$ sullen gehouden wesen, deselve natie te dienen voor gelijcke betalinge als de jngeboorne van Persia: Wordt geconsenteerdt.

9.

Dat alle officieren ${ }^{5}$ in Persia gehouden sullen wesen, de Nederlandtsche natie te provideeren met huijsvestinge, victualie, paerden als alle het geene dat op haer lieden soude mogen versoght werden; mede soo 't noot ware met volck te accompagneeren van d'een plaets op d'ander tot meerder verseekeringe van haerlieder persoonen en goederen: Consenteert van gelycke.

10.

Dat het huijs van de Nederlandsche natie in Persia sall gepreveligt ${ }^{t}$ weesen met alle vryheeden, sonder eenige subjecte ${ }^{6}$; dat ook niemandt van de justitie sall vermogen, daerinne te komen sonder verloff van die geene, die van wegen die natie 't gebiet hebben zall. Ende zoo ymandt met gewelt daerinne willde comen, dat de Nederlanders sullen vermogen t' sellve met gewellt te resisteren: Consenteeren.

11.

Dat de Nederlanders sullen mogen verkiesen plaetse tot exercitie van haer religie, deselve publickelijck administreren, sonder eenige verhinderinge offte molestie: Consenteerdt.

\section{2.}

Sullen vermogen te koopen ende uijt het landt te voeren Chrissten

1 Hier is het woord "ontnomen" uitgevallen. (Vgl. Valentijn, t. a. p., bldz. 293).

2 Sardar, sirdar. (Vgl. Hobson-Jobson, p. 638, vgl. ook p. 653, sub voce "Sudder".)

3 Mukari $=$ verhuurders van kameelen.

4 Baschy. Het hoofd van een karavaan wordt nog steeds caravanbasji genoemd.

${ }^{5}$ Natuurlijk hier in de meer algemeene beteekenis van ambtenaren.

6 Subjectie bij Valentijn. 
slaven sonder eenige verhinderinge, principalijck ingeboorne van onse landen en subjecten van de Hoge Mogende $\mathrm{H}^{\mathrm{n}}$ Staten Generl der Geunieerde Nederlandsche provintien.

13.

Soo ymandt van de Nederland ${ }^{\text {rs }}$ Mahumetaens wierde, sall den opperste offte president ${ }^{1}$ vermogen, soodanige persoonen met alle hare goederen in sijn gewelt te nemen en met de eerste gelegenth ${ }^{t}$ versenden, daer 't hen zall gelieven.

Andwoordt op den $12^{\mathrm{e}}$ ende $13^{\mathrm{e}}$ artykell.

Soo der eenige slaven van uwe natie bevonden wierden, sult deselve mogen koopen met weten van de justitie, mits doen blyckende, dat een ondersaet van de Hoog Mogende $\mathrm{H}^{\mathrm{n}}$ Staten is.

Dat niemandt $\mathrm{u}$ volck sall vermogen aen te houden offte te bewegen, om Moors te worden ende de geene die tegen uwen wille Moors wierd, sult ghij vermogen te verzenden, daer 't $\mathrm{u}$ beliefft.

14.

Offte geviele, dat Godt verhoede, jemandt van de Nederlandsche natie eenigh persoon, van wadt natie het soude mogen wesen, dootsloege offte eenigh ander crime offte delict committeerde, sullen sodanige persoonen niet staen ter justitie van die van Persia, maer sullen van haren president offte overhooffden gestrafft worden naer gelegenth $^{t}$ van saeken ende gelijck sijlieden goedt sullen vinden te behooren.

\section{5.}

Off eenigh Nederlander bij vrouwen bevonden wierde, dat geen officier sullen vermogen soodanigh persoon te apprehenderen, maer dat van hunne eijgen overhooffden sullen gestraft worden, naer dat schulldigh bevonden wesen.

\section{Andwoorde op den $14^{\mathrm{e}}$ en $15^{\mathrm{e}}$ artijkell.}

Jn cas van dootslagh offte ander delict wordt $\mathrm{u}$ het reght over de uwe vergundt, mits dat ghij 'tselve sullt adminisstreren tot contentemendt en volldoeningh van justitie, gelijck van onser zyde tegen uwe natie alltijt sall gehouden werden.

Soo den officier jemandt van u volck by Moorsche vrouwen vont, sall desellve persoonen in uwe handen leveren, op dat van uwe naer merite des delickte gestrafft worden.

1 Nl. van de Nederlanders, dus de vertegenwoordiger der O. I. C. in Perzië. 
16.

Dat de Nederland ${ }^{\text {rs }}$ sullen mogen verkiesen een plaetse, bequam tot begravinge haerer dooden en hunnen overledenen op hare gewoonlycke maniere ter aerden brengen sonder verhinderinge.

Andwoordt: Ordonneere uwe zepellture ${ }^{1}$ die van de oellfallijnen ${ }^{2}$ allwaer ghy uwe overledenen op uwe maniere sonder verhinderinge moght beaerden.

17.

Dat den tolck offte tercunano ${ }^{3}$ van 't Nederlandt huijs sall gepreviligeerdt wesen met niet minder vrijh ${ }^{t}$ als ymandt van de Nederlandsche natie, sonder dat men denselven jwers in zall mogen beschulldigen offte lasstigh vallen.

18.

Niemandt zall vermogen, aen eenige persoonen, in dienste van de Nederlandtsche natie wesende, eenige overlast te doen offte hinderlijck te zijn, maar dat alle persoonen, Parsianen, Armenien, Turcken, Mooren, Benjanen 4 hun sullen mogen in dienste van de Nederlandtse natie emploijeren, sonder daer over gemolesteerdt te worden.

\section{Antwoordt der $17^{\mathrm{e}}$ en $18^{\mathrm{e}}$ artykell.}

Jck gebiede alle de mijne, van wadt qualiteijt sij soude mogen wesen, uwe huysen offte woningen ende persoonen met alle respect ende beleeffth ${ }^{t}$ te beiegenen ende niemandt in uwe dienst zynde, van wat natie hij soude mogen wesen, te molesteren, als mede dat ghij offte den uwen niemandt van mijn subjecten sullt persuaderen om van religie te anderen.

19.

Bij alldien, dat Godt verhoede, eenige schipbreukinge quame te geschieden aen eenige stranden onder de jurisdictie van Syn $\mathrm{May}^{\mathrm{t}}$, allwaer de goederen soude mogen gevist offte door eenigh jmaginabell middell werden gesallveerdt, sullen alle ministers gehouden wesen, soodanige geviste goederen aen de Nederlandsche

1 Sepultura (Portugeesch: begraafplaats).

2 Een schrijffout voor Djoelfallijnen, nl. de bewoners van Djoelfa ten zuidoosten van Ispahan. Deze plaats was gesticht geworden, toen, na de verovering van Armenië door sjah Abbas, de bewoners van het daar gelegen Djoelfa gedwongeh werden, naar Perzië te verhuizen. Zij waren Christenen.

3 Terguman.

4 Hindoe-Kooplui, vooral nit Guzerat (Gujarat) in het noordwesten van Vóór-Indiè. (Vgl. o. a. de bewijsplaatsen bij Hobson-Jobson, p. 48, f.) 
natie sonder pretentie van eenigh reght weder te geven: Wordt geconsenteert.

20.

Dat de Nederlanders sullen vermogen, uijt Persia te voeren paerden alsmede allderhande soorte van beestiaell, sulcx als hun lieden sall goedt duncken.

21.

Dat men ons van het tegenwoordigh gebroghte cargasoen in Siras offte Ormus namaels geen tollen en sall mogen eyschen, onder wadt pretecxt dat het ook soude mogen wesen.

\section{2.}

Dat geen sadaers ${ }^{1}$ sullen vermogen, ons raddary te eysschen in wadt plaetse daer 't zoude mogen wesen.

\section{Andwoordt op de 3 jongste artykell.}

Allderhande coopmanschappen sult mogen uijtvoeren behallven paerden en wadt generalijck verbooden is, ten ware ick u sulcx consenteerde. Aengaende reght op de goederen, daerop hebbe ick hier vooren geandwoordt ende allsoo Siras en Laer onder 't gebiedt van den hertogh ${ }^{2}$ staet, wadt die u vergunt conformeere ick van gelijcken.

\section{3.}

Den ambassadr uyt Nederlandt comende van wegen de Hooge Mogende $\mathrm{H}^{\text {ren }}$ Staten, sijn princelijcke Ex ${ }^{\text {tie }}$, met last om meerder vrijh $^{t}$ te versoeken als in de voorschreven artykulen begreepen is, beloofft Sijn Koninckl. May ${ }^{t}$ soodanigh versoek naer discrete ${ }^{3}$ en redenen te verwilligen: t'Sall sulcx sijn.

Overgeleverdt in handen van Sijn May ${ }^{t}$ ady $15^{\text {e }} 8^{\text {ber }}$ : ende bevesstight wederom ontfangen ady $21^{\mathrm{e}} \mathrm{g}^{\text {ber }}: \mathrm{A}^{\circ} 1623{ }^{4}$.

1 Schrijffout voor "radaers"?

2 De khan van Sjiraas.

3 Discretie?

${ }^{4}$ Dat de eigenlijke datum der definitieve sluiting is geweest 21 November, blijkt óók uit het Onuitgegeven extract journaal van Visnich. Valentijn heeft: 17 November. Deze datum komt ook voor op enkele andere exemplaren van de overeenkomst. Vermoedelijk is dit de dag der bekrachtiging door den Sjah. Zie echter hierachter het tractaat van 1642 . 


\section{SOLOR- EN TIMOR-GROEP.}

\section{Januari 1624. ${ }^{1}$}

De strijd door ons tegen de Portugeezen in deze gewesten gevoerd werd voortgezet, ook na de hèrinbezitneming van het fort Henricus (Zie hiervóór, No LIX), terwijl de sandelhouthandel zijn gang ging, zij het ook, dat hij geen groote winsten afwierp, doordat vooral de Portugeezen zich geduchte concurrenten bleven toonen. Het sandelhout diende ons in de eerste plaats voor den handel op China en de Kust van Koromandel. Ook slaven hoopte men te kunnen opkoopen. Sedert 1622 stond aan het hoofd van het fort, het garnizoen en den handei Jan Thomaszoon Dayman (1622-1625), maar gebrek aan volk was voor ons een beletsel om de Portugeezen te weerstaan in het drijven der commercie. Ook verschillende onzer bondgenooten voldeden niet altijd aan de contractueele verplichtingen. Zoo was over't geheel de toestand in deze kwartieren alles behalve schitterend en de Hooge Regeering deed weinig , om in die omstandigheden verbetering aan te brengen. $\mathrm{Zij}$ zou den handel op die streken liever in handen van particulieren hebben gezien; maar, zoolang dit niet of niet in voldoende mate plaats vond, meende zij, onze positie te moeten handhaven, hoe goed of kwaad zulks ging. Maar toch, er waren belangrijker betrekkingen te onderhouden dan met dezen uithoek.

Dayman hield zich dan ook staande. Een der uitingen van zijn optreden is onderstaand contract, waarvan hij schrijft: „Op 17 Januari (1624) hebben met die van Woclel ofte Carma aan 't fort, den 22 op hunne strande in presentie van alle d'inwoonderen den pays beswooren, volgens nevensgaand contract." (Onuitgegeven missives van de Hooge Regeering naar Solor van 15 October 1622 en aan Bewindhebbers van 20 Juni 1623 en 27 October 1625 ; van Dayman aan de Hooge Regeering dd. 23 Augustus 1623, $20 \mathrm{Mei}$ 1624).

Dgiany ${ }^{2}$ dan sompa dang ${ }^{2}$ kita orang Karma ${ }^{3}$ souda boat dangan Command ${ }^{r}$ cota Hollanda, dangan chilly Partany, dangan singagy Lamaguera, dan singagie Lamhaly, dang singagy Toureon Adenare, dang singagy Sorbyty ${ }^{4}$, dang singagy Touua dang sacaliamyne (?) ${ }^{2}$ singagy panty dang singagy gonnong, raydt radia Hollanda derry tana Soolor jnnij.

Partama kitorangh Carma dan rayt gonnong kita samoingina ${ }^{2}$ jecot d'giangy Command ${ }^{\mathrm{r}}$ Schot ${ }^{5}$ baggy orangh Soloor samoingina ${ }^{2}$ jecott.

Sybagy lagy kitorangh Carma dangan t'chily Partany dan saccali-

1 Uit het Contractboek.

' Djandji; jang?; sakaliannja?; samoewanja?

3 Een kampong op Solor (of die op Andonare?)

4 Vgl. hiervóór, No LIX.

• Apollonius Schotte (Vgl. hiervóór, bldz. 119, 138). 
anngue singagy patty ${ }^{1}$ derry tanna Soolor nangh jecot mouson ${ }^{1}$ frangij, dat barangh sawata secard giangia Hollanda dangh radia Molucco pontgue di bava anguin jnij.

Sawatu laggij d'gica adda barrangh orrangh pomgue outtan kallou barrangh demguanguie (?) derry negry satou capada negry laing, raijt kita samoingine tuangine tiada menboole tancapgue passar melainckangh minta jangh chiapia peggan passar jny, aggar gianguan gampar dallam passaramgue (?) callou barrangh mantchourij ${ }^{1}$, barrangh parlente o barrangh chiapa bonnongh orangh sammougnij candatij command ${ }^{\mathrm{r}}$ cota Hollanda desinij sourou tancap deaamgue caulo barrangh orangh laingh boat candaty tiady bry touw daulou capada capala passar atas segala orrangh dan capala nangh pomguie pantingh menbounongh desitou depan tongall radia Hollanda o callou barrangh hoccon laingh candaty seggalla orangh dan touaingue nangh pegan panting dang passar jttou.

Sawaty laggy barrangh calou sammoingine callou Lauweijong, Lamaquere, Adenarij, Serbyte, Tourron, o Lomhala o callou orrangh Hollanda candirij maijrousacan d'giangy dan sompa jnny, mana bitchara orrangh sammoingnie nang tida adda bersala boat $\mathrm{p}^{\mathrm{r}}$ dea d'allam cota Hemdricque de tanna Soloor pada tauwan Zijseherrij baulangh Roobij agher ${ }^{2}$ Jesene naminanguie quirij kitta orangh tauwen 1624 den $22^{\mathrm{e}}$ dagh Janwary ende was onderteekent J. Tz. Dayman, Jan de Gorney ${ }^{3}$, semgagij Lamaquery, Cristoffell, allvres ${ }^{4}$, Anthonij, allvres ${ }^{4}$, semgagie Lamhala, semgagie Tourron, kitchyll Partanij.

\section{KUST VAN KOROMANDEL.}

\section{Augustus 1624. 5}

In 1624 werd Maarten IJsbrantszoon of IJsbrantsz. directeur of gouverneur van de Kust van Koromandel. Ook hij beleefde moeilijke tijden.

1 Panti? = pantai. - Moesoeh feranggi? - Měntjoeri. - Van den zeer bedorven tekst worden eene verbetering en eene vertaling beproefd in het Aanhangsel hierachter.

2 De maand Rabi' al-âchir.

3 Jan de Horney. Deze werd een der opvolgers (1626-1629) van Dayman, toen deze in 1625 met zijn gezin naar de Portugeezen overliep. (Vgl. TieleHeeres, Bouwstoffen, II, bldz. XXIII, noot 3).

- Vermoedelijk het Portugeesche alféres = vaandeldrager. Het woord is nog in de Molukken gebruikelijk. (Vgl. De Clereq, Ternate, bldz. 324.)

5 Uit het Contractboek.

7• Volgr. III. 
Behalve allerlei ernstige onaangenaamheden door de Nederlanders, juist vóór zijne komst, te Mazulipatam ondervonden (Vgl. Dagh-Register $1624-1629$, bldz. 33, 58, 189; onuitgegeven missive van Visnich uit Ispahan aan G. G. \& R. 18 Januari 1624: hij had de Kust in 1623 bezocht), bleven ook onder zijn bestuur de binnenlandsche "troublen in de landen van Paliacatte alsnoch continueeren." (Vgl. hiervóór, bldz. 158, v.) Dit alles verklaart voldoende onderstaande overeenkomst.

Accoordt tusschen Comp ${ }^{\mathrm{s}}$ gouvern $^{\mathrm{r}}$ op Chormandell ende Tchickitakora Pedderagijn ${ }^{1}$ cum s $^{8}{ }^{2}$, aengegaen jnt jaer $58^{\mathrm{e}}$ den $5^{\mathrm{e}}$ der $6^{\mathrm{e}}$ maendt naer Jentive rekeninge en naer onse jnt jaer 1624 den $19^{\mathrm{e}}$ Augustij stijlo novo.

Aen $\mathrm{S}^{\mathrm{r}}$ Marten $^{3}$, cap $^{\mathrm{n}}$ der fortresse van de Holland ${ }^{\mathrm{rs}}$ in Palleacatta, hebben wij ondergeschreven Tchikatacora Pedderagie, Pouckapilla, Naripiraguariddy, gegeven een brieff van verdragh, met eede bevestight, dat wij met UE. ende ghy met ous in alles sullen continueeren als vrienden in vriendschap eeuwelijck, waerover wij van onser sijde belooven in alle den tijt van UE. ende daernaer aen allen den geenen die in UE. plaets zoude mogen komen te succederen tot allen tijden ons te dragen als voorschreven, en soo in dese plaetse $\mathrm{U}$ eenige negotieren begeerdt door ymandt te gebieden offte verrighten, zall t'selve beter als in U plaets door ons ten goeden eynde gebraght worden. UE. eenige moeyte, overlast, oorlogh offte eenigh int welck $U$ ons zou mogen van doen hebben overkomende, belooven wij $\mathrm{U}$ t'allen tijden, daer toe versoght zijnde, te assisteren met alle ons maght ende vermoogen.

Belooven mede, judien onder ons drie voorgenoemde persoonen hem in eenige deelen deses ymandt misgreep, verliep offte eenige jmbruliado ${ }^{4}$ soghte, sullen met hullpe van UE en de ander twee de saeke wederom tenreghten brengen ende met alle middelen sien te effenen nae $U$ wellgevallen. Mede belooven wij, dat van nu voortaen aengaende de coopluyden Asstopachittij ende den Patnamswanij ende alle de jnwoonderen der steden Palliacatta wij tot allen tijden in vriendschap met hun sullen blijven ende in alle travailgien ${ }^{5}$ zullen helpen.

1 Vgl. over hem hiervóór, bldz. 159.

2 Cum suis.

3 Marten IJsbrantsz.

4 Embrulhado (Portugeesch): oneenigheid, twist.

5 Trabalho (Port.): moeilijkheid. - Geheel deze zinsnede der overeenkomst is alleen van belang, voorzoover daaruit blijkt, dat de binnenlandsche twisten te Pulicat en omgeving ook de Nederlanders in hunnen handel bemoeilijkten. 
Dit alles belooven wij, gelijck UE. ende nakomen ordonneert, in alle dilligentie ende oodtmoet naer te komen. Hier op zweeren wij bij ons vader ende moeder, dat hierinne niet nalatigh sullen zijn. Getuijgen hier aff is do Eckanbargie ende Asstapachittij Patmanaba, Secretaris. Was onderteekent T'chickitacora, Pouckapilla, Narripiraguariddij. ${ }^{1}$

\section{CHINA.}

\section{2-24 Angustus 1624. 2}

Reeds dadelijk bij den aanvang onzer pogingen, deel te krijgen in den handel van het Oosten, stonden de „eoninchrijeken van China” op het program onzer kooplui en pioniers. En lang duurde het niet, of het Hemelsche rijk werd door de onzen bezocht: en wel in 1601 door schepen van de vloot van Jacob Corneliszoon van Neck, onder diens eigen leiding. Sedert dien tijd heeft men wel nimmer deze aangelegenheid uit het oog verloren, maar toch zou het geruimen tijd duren, dat men haar zeer beslist een tijdlang op den voorgrond bracht. Coen toch wilde niet alleen aandeel in dien handel hebben, maar hem monopoliseeren door andere natiën er van uit te sluiten en op die wijze de Chineesche producten (zijde in de eerste plaats) op de Europeesche en Aziatische markten (Japan, Vóór-Indië, enz.) te brengen. In 1622 werd een flinke vloot gereed gemaakt onder bevel van Cornelis Reijersen, aan wien werd opgedragen, te trachten: zich van het Portugeesche Macao meester te maken, van de Chineesche autoriteiten der kustplaatsen den vrijen handel en het monopolie te verkrijgen en zich te vestigen op de Pescadores of op Formosa om den handel der Spanjaarden van Manila op China zoodoende te kunnen verhinderen, enz. enz. „Soo na de insinuatie de Chineeszen handel zonder uitstel van tijd niet vererijgt ende geen behulp, vriendschap, noch alle nootlijekheden van de Chynesen becompt, maar niet dan uitstel of quaet bescheet verneempt, zal UEd. soo haest op deen plaetse off dander redelijekerwijs verseeckert zijt..... de Chineesen d'openbaren oorloch verclaren ende haer alle mogelijcke aff breuck doen, geen plaetsen, joncken, noch volck van de Chynesen verschonende..... Trachtende soo veel volex, mannen, vrouwen en kinderen te becomen als doenelijck is, zoo om U daer mede te behelpen, als omme Batavia, Amboyna ende Banda te peupleren....." Zoo Coens' instructie voor Reyersen.

De expeditie heeft niet aan de daarvan gekoesterde verwachtingen voldaan. De aanval op Macao mislukte en men begaf zich naar de Pescadores, terwijl men tevens een onderzoek instelde naar de gelegenheid van Formosa. Voorloopig besloot men, een fort op de Pescadores te

1 Ik heb niet de moeite genomen, te trachten deze namen van voor ons geheel ondergeschikte beteekenis terecht te brengen. Over "Asstripachittij" Zie hierachter $\mathrm{n}^{\circ} \mathrm{XCII}$.

${ }^{2}$ Overgenomen uit Groeneveldt, Nederlanders in China; $\mathbf{i}$, bldz. 287, v.v. 
vestigen, met welks bouw in Augustus 1622 werd begonnen, en wel op het eilandje Pehoe (Pong-hoe).

Bij de onderhandelingen met de Chineesche autoriteiten begon onze nieuwe vestiging het punt te worden, waarom alles zich bewoog. Wij wilden Pehoe niet verlaten, de Chineezen wilden de vreemdelingen niet dulden op deze eilandengroep, die behoorde tot "de jurisdictie van China." En de vijandelijkheden namen een aanvang. Deze hebben geleid tot onze verdrijving uit de Pescadores, maar tevens tot onze vestiging (1624) op Formosa. Onderstaand schrijven, dat wel een unilateraal karakter heeft, maar waarbij de Nederlanders zich hebben moeten neerleggen, geeft het eindresultaat der onderhandelingen weer tusschen de Nederlandsche en Chineesche autoriteiten. Ik neem het dáárom hier over. Het schrijven (22 Augustus) is van den totok ${ }^{1}$ te Amoy. (Vgl. Groeneveldt, Nederlanders in China, I, passim; Dagh-Register 1624-1629, o. a. bldz. 139 v.v.)

Soo als UEd. ${ }^{2}$ bij de sijne versouckt te treden in een vrundelijck accoort mette Chineese natie, sal UEd. gelieven te verstaen hoe dat het voorleden jaer den Commandeur Reijersen, comende inde plaetse van Hockcheu ${ }^{3}$, aen den Combon ${ }^{4}$ Sion ende Toutock Sou ${ }^{5}$ versocht heeft, dat syluyden souden gelieven te senden joncken met coopmanschappen naer Calappa ${ }^{6}$, om aldaer den vorder Chineesen handel te contracteeren, beloovende ondertusschen het fort te breken, de plaetse van Pehou te verlaeten ende sich naar sijn land te vervoegen, sweerende hiermede in geen gebreke te sullen blijven. ?

Mijn Coninck in sulcke vaste belofte vertrouwende heeft terstont naer Calappa voor gesanten afgevaerdicht Cenchon Tansouyn ende Wangsan ${ }^{8}$, met eenige coopmanschappen ende waren om aldaer te coopen ende vercoopen, zulcx dat wy in alles woort hebben gehouden.

$\mathrm{Nu}$ compt UEd. ende seght, dat [gij] een ambassadeur medebrenght om herwaerts naer Amoy aen te seynden, versoeckende

1 To-tok, opperbevelhebber der troepen in de provincie. (Groeneveldt, t. a. p. bldz. 139 , noot 2,154 , noot 1 ).

2 Deze brief was gericht aan $\mathrm{D}^{\mathrm{r}}$ Martinus Sonck, die in 1624 door den Raad van Indië was aangewezen als opvolger van Reijersen, welke om zijne vervanging had verzocht. (Groeneveldt, t. a. p., bldz. 255).

$s$ Hok-tsioe of Foochow, de zetel van den gouverneur der provincie Hokkiën of Foekiën (Groeneveldt, bldz. 17, noot 2).

4 Combon is eigenlijk gouverneur-generaal, maar wordt hier gebruikt voor den gouverneur van Hokkiën (Groeneveldt, bldz. 17, noot 2, 117, noot), Siong.

${ }^{5}$ De to-tok van Amoy.

- Soenda Kalapa, Djakatra, Batavia.

7 Wat inderdaad gebeurd was. (Vgl. Groeneveldt, t. a. p., bldz. 156, 288).

8 Vgl. Groeneveldt, bldz. 164,241 , v.v. 
UEd. dat daerop een van onse mandorijns naer Pehou mochte gesonden worden om met UEd. te spreken. Sijn alreets geen gesanten naer Calappa gesonden geweest om van den handel te spreken? Wat ist noodich daer meer van te repeteren?

'Tschijnt UEd. nyet anders int sin hebt als den tijt van jaer tot jaer te prolongeren, als nyet eens thoonende genegentheyt te hebben omt fort te breken nochte Pehou te verlaeten, in vougen dat wij ons versekert houden dat op 't woort van de Hollantse natie niet veel is te vertrouwen.

Ino Chioppyn ' heeft onlangs herwaerts geschreven hoe dat den Heer Commandeur hadde belooft de plaetse van Pehou binnen den tijt van vier weecken te verlaeten ende sich naer Tayouwan soude vervoegen, waerin andermael sijn woord nyet gehouden heeft. Wat vertrouwen wil UEd. dat wij in sulcke beloften stellen sullen?

Doch dies alles nyettegenstaende soo UEd. nu noch compt met eene goede meeninge om met ons in onderhandelinge te comen ende dat met geene valsheyt off bedroch besindt sijn, verlatende op t'alderspoedichste de plaets van Pehou, sijn wij bereyt persoonen derwaerts te senden om de waarheit van alles te ondertasten.

Aldaer is nu in Pehou Siomping ${ }^{2}$, die van ons alle volle macht heeft; alles wat UEd. met hem contracteert, sullen wij ons verbinden alhier volcomentlijck te confirmeeren.

De Chineesche generael (tsong-ping) in de Pescadores zond den 23 Augustus nog den volgenden brief:

Gelijck wij vertrouwen in de goede intentie ende goetharticheyt van UEd., soo seggen wij van onse sijde, soo UEd. het fort afbreekt, vertreckende met de navale macht ende wederom overleverende Pehou, vertreckende alsoo naar Ilha Formosa ofte Tayouwan, dat wij ons verbinden den handel van coopmanschap voor. UEd. te sullen openen, sonder oyt meer van voorgaende oorlogs ofte vijandlijcke feyten te verhaelen, met sulcke conditien dat UEd. navale macht de onse noch ter zee nochte met invasien int lant van China niet sullen beschadigen. ${ }^{3}$

'Hiermede wordt zeker dezelfde bedoeld als met "Siomping": zie beneden; noot 2 .

2 Tsong-ping, een generaal; hier de bevelhebber der Chineesche krijgsmacht in de Pescadores. (Groeneveldt, bldz. 136, noot 3, 280, noot 1).

s $\mathrm{Na}$ nòg een vruchtelooze poging tot verdere onderhandelingen, hebben de Nederlandsche autoriteiten in de Pescadores zich hierbij moeten neerleggen. Den 26 Augustus begon men met de slooping van onze sterkte 


\section{MOLUKKEN.}

\section{November 1624. 1}

Ternate had aan zijn gezag onderworpen Kalongan op Groot-Sangi. Het viel echter in 1624 weder van Ternate af en dit rijk vroeg thans hulp van de O. I. C. Vandaar onderstaand contract. (Vgl. Tiele-Heeres, Bouwstoffen, II, bldz. 40, v., 43, v. 79). De tocht mislukte jammerlijk, doordat het schip de Trouw, naar Kalongan gezonden, dáár verging.

Accoordt geraemt ende beslooten tusschen de groot maghtighe Moedafar, coninck van Ternaten etc ${ }^{\mathrm{a}}$, kitchill Aly, cap ${ }^{\mathrm{t}}$ laout, ${ }^{2}$ eenige principale overhooffden ter eender ende $\mathrm{d}^{\prime} \mathrm{H}^{\mathrm{r}}$ Jacques Lefebure, ${ }^{3}$ raedt van Jndien, gouvern ${ }^{\mathrm{r}}$ en directeur over de Moluccos wegen d'Hooge Mogende $\mathrm{H}^{\mathrm{n}}$ Staten Gener ${ }^{1}$, syne princelycke Excellentie van Orangien etca., de $\mathrm{Ed}^{\mathrm{e}} \mathrm{H}^{\mathrm{rn}}$ Bewindhebberen der Vereenighde Oostjndische Comp ${ }^{e}$ ende den Ed ${ }^{e} \mathrm{H}^{r}$ Gouvern ${ }^{r}$ Gener ${ }^{r}$ van Jndien sampt die van syn $\mathrm{Ed}^{\mathrm{en}}$ raden ter andere zijde, te weten:

\section{1.}

Eerstelijck voorengem ${ }^{t} \mathrm{H}^{\mathrm{r}}$ Gouvern ${ }^{\mathrm{r}}$ Lefebure met die van synder $E d^{n}$ rade staen toe en belooven, den coninck van Ternaten, Cap ${ }^{t}$ laut, sampt eenigh synder orangkaijs, op haer furieus ${ }^{4}$ versoek en lanck aenhouden, met 't schip de Trouw, geprovideert met volck van oorloge, ammonitie, vivres als andere noodtdrufften, t'assisteren, om een explojet op die van Coulougo, ${ }^{5}$ hun rebellen, met gemeender maght te doen, alle den buijt, die Godt Allmaghtigh int generl $^{1}$ soude verleenen, geeue uijtgesondert, soo van slaven als andere goederen, daer in te laden, ten eynde deselve naer behooren op de wedercomste allhier magh gedistribueerdt werden.

2.

Te weeten van alles hij, coninck, Cap ${ }^{t}$ laout, tsampt orangkays, d'eene, ende gem $^{\text {te }} \mathrm{H}^{\mathrm{r}}$ Gouvern ${ }^{\mathrm{r}}$ d'ander helffte; tot wellcken eynde sullen gedoogen, visite soo alldaer ter plaetse als allhier op de wedercomste in haer correcorren, ander vaertuygh, huysen, hutten,

aldaar, en daarop vertrok Sonck naar Formosa, om maatregelen te nemen voor onze definitieve vestiging op dit eiland. (Groeneveldt, bldz. 290; DaghRegister 1624-1629, bldz. 144).

1 Uit het Contractboek.

2 Kapitein laoet: admiraal, vlootvoogd.

3 Jacques Lefebvre of Letebure was Nederlandsche gouverneur der Molukken van 1622-1628 (Tiele-Heeres, Bouwstoffen, II, bldz. II).

4 Vermoedelijk schrijffout voor: serieus.

s Kalongan. 
gehughten gedaen en alles naer behooren ten overstaen der gecommitteerde aen wederzijde gejnventariseerdt, opdat niemandt van sijn gereghtigh $^{t}$ gefrusteerdt ende emulatie g'eviteerdt werde.

\section{3.}

Sullen mede hij, cap ${ }^{t}$ laout, ende oranghkays gehouden wesen, ten tijde van de repartitie te betalen de helfft van alle de oncossten ende vivres, die tot behoeffte van de veroverde persoonen, gedurende den tijt dat de deylinge niet geschiet is, door d'onse soude mogen verstreckt wesen.

\section{4.}

Van gelycken alle 't gundt gedurende de vojagie Capt laut, eenige andere orangcays offte hun dienaers souden mogen t' haren versoecke en behoeffte genooten hebben, alle welcke voor de repartitie van 't gros sullen gedoogen, sonder wederspreken affgetrocken te worden.

5.

Cap $^{t}$ laout voorn ${ }^{t}$ sall sigh met eenige van de sijne int voorschreven schip embarcqueren en soo haest' selve met Godes hullpe ter gedestineerde plaetse gearriveerdt sij, dadelijck sonder vertoeven [en] uijtvlught soecken noghte onnutte pitcaringen te maeken, t' voorgenomen exployct int werck stellen opdat soo costelycken schip geenen tijt te vergeeffs .....

6.

Belovende mede hij, coninck, Cap ${ }^{t}$ laout ende orangcayen voorn ${ }^{t}$ gedurende dese reyse te water offte te lande geenige secreete noghte openbaringe pitcaringhen te houden, noghte van eenige andere hun ondersaten gedoogen te doen, sonder onse gecommitteerde, tot vollvoeringe van 't exployct geordonneerdt, present te wesen, opdat alles oprechtelijck, sonder oorsaeke van aghterdoght te geven, magh geschieden.

7.

Verbinden sigh mede, gedurende d'absentie van 't schip in tijde van noodt en sulx van voorengem ${ }^{t} \mathrm{H}^{r}$ gouvern ${ }^{r}$ versoght wesende, met allderley vaertuygh, daer sulcx van doen zij, syn Ed ${ }^{\text {en }}$ t'assisteren, t'zij om advysen naer 't schip te zenden offte eenige plaetse te secoureren, als ware bondtgenoten toestaet te doen.

1 Hier staat "questie", wat natuurlijk een zonderlinge sehrijffout is. 
8.

Beloovende mede, geduijrende de reijse geenige exployten, 'tzy te water offte te lande op geenigerley wyse, onder wat pretext sulcx soude mogen geschieden, voor te nemen nogh te laten doen, sonder advys van de voornoemde gecommitteerde.

9.

Sullen datellijck alle prinsen sonder vertoeven gejnventaryseert ende voorschreven gecommitteerde in bewaernisse gegeven worden, jn conformite van 't $2^{\mathrm{e}}$ artykell deses accoords.

Alle welcke hier voorengem ${ }^{t}$ artykeleu wy ondergeschreven Moedafar, coninck van Ternaten, citchill Aly, cappiteyn laout en Jaques Lefebure, Raedt vau Indien, Gouvern ${ }^{\mathrm{r}}$ en directeur over de Molucques, sampt voorengem ${ }^{\text {te }}$ raden, beloven aen wederzyden op onse woorde en waerh ${ }^{t}$ vast en onverbreckelijck sonder eenige contraventie naer te comen. Soo waerlijck hellpe ons Godt Allmaghtigh. Tot dien eynde hebben twee accoorden met ons eijgen handt, alleens luijdende, t'eene in Maleyse en desen in onse Nederlandtsche taele, onderteekent.

Alldus gedaen ende gearresteerdt t'onser vergaderinge in de stadt Malleye op 't eylandt Ternaten, deesen $12^{\text {en }} 9^{\text {ber }} A^{\circ} 1624$.

\section{BANDA.}

23 December 1624. ${ }^{1}$

De Oostkust van Ceram en de eilanden ten Zuidoosten daarvan waren een wijk- en schuilplaats geworden voor de Bandaneezen, welke voor de Nederlanders van hunne eilanden waren gevlucht, vooral na de gebeurtenissen van 1621. Zij kregen dáár grooten invloed en waren er, van Nederlandsch standpunt gezien, zéér gevaarlijke elementen, zoodat pogingen werden aangewend, hen van dáár te verdrijven. (Vgl. Tiele, Bouwstoffen, I, bldz. 316; onuitgegeven missives van Izaak de Brune, tijdelijken gouverneur van Banda, aan den G.G., 16 Mei 1623, van Van Speult aan den G.G. 5 Juni 1623, enz.) In 1624 gelukte het aan Van Speult, het gezag der O. I. C. gewapenderhand te doen gelden: onderstaand contract was daarvan het resultaat.

1 Overgenomen uit Valentijn, Ambon, II, b, bldz. 54 v.v.

Ik plaats dit stuk onder Banda, omdat in 's Compagnie's tijd de Oosthoek van Ceram en de eilanden ten Zuidoosten daarvan meest van Banda uit bestuurd werden. 
Op huiden dezen 23 December A. 1624 compareerden in 't Kasteel van Amboina voor den E. Heer Herman van Speult, Raad van Indie, ende Gouverneur van Amboina, wegens de E. doorlugtige Hoog Mogende Heeren Staten Generaal, den Heere Mauritius, bij der gratie Gods, Prince van Orangie enz. ende de E. Heeren Bewindhebberen der vereenigde Oost-Indische Compagnie, ende die van den Raade, Orang Kaja Sobo, wegens die van Ceram-Laoet, en Orang Kaja Simon Bal, uit den naam, en van wegen die van Heralieu , ${ }^{1}$ Keffing, Goram, Goeli Goeli, Oerong en Coac, ${ }^{2}$ met volkomen magt en authoriteit, omme haer met den gemelden Heer Gouverneur te reconcilieren, alzoo de vorige hostiliteiten en ongevallen verklaaren ontstaan te weezen door instigatie der Bandanesen: om met den anderen in goede, vaste, sincere en onverbrekelyke vriendschap te treden, ter presentie en overstaan van Capitein Hitoe, nevens de hoofden en Orang Kaja s van de Oelisiva's en Oelilima's, als intercesseurs en getuigen op naarvolgende conditien.

1.

Eerstelyk, dat de onderdanen van de Ed. gemelde Hoog Mogende Heeren Staten Generaal vry ende vrank hare stranden zonder verhinderinge zullen mogen frequenteren, 't $\mathrm{zy}$ om te handelen, verversinge ofte water te halen.

2.

Item, ten tweeden, dat gemelte Orang Kaja's niet en zullen vermogen eenige alliantien, ofte verbonden te maken met Spanjaards, Tidoresen, Macassaren, Bandanesen, Engelschen, Deenen, Franschen, ofte andere natien, buiten expres consent, en voorweten van gemelde Gouverneur, ofte zyne successeurs.

3.

Dat gemelde Orang Kaja's, ofte hare gecommitteerden, het zy dat zy waaren of geene en hebben om te handelen, jaarlyx ten minste eeus in 't laatste van 't wester Moesson aan 't Kasteel

1 Deze plaats kan ik niet terecht brengen.

2 Koewakoe, de Zuid-Oosthoek der Elpapoeteh-baai, waar wij in 1621 het fort Harderwijk hadden gebouwd bij Amahei. (Bouwstoffen, I, bldz. XLVIH, $296,312,315,327)$. - Of is hier met Coac bedoeld poeloe Gofa? 
zullen gehouden wezen te komen omme met gemelde Heer Gouverneur, de Oelisiva's en Oelilima's, te pitsjaren, op dat aan wederzyden de klagten van mishandelingen mogen gehoort, en naar behooren gecorrigeerd werden.

4.

Beloven mede gemelde Orang Kaja's van Ceram, dat zy geene andere plaatzen en zullen aan doen, maar regt aan het Kasteel komen, op dat $\mathrm{zy}$, op andere plaatsen willende handelen, behoorlyke pas-cedulle van den Gouverneur voornoemd mogen obtineren, en daar door voor schade van de heenkomende schepen mogen bevryd zyn.

5.

Item, dat zy die van Key, en Aroe, ${ }^{1}$ als alle andere onze onderdanen, vry ende onverhinderd hare stranden sullen laten frequenteren, zoo in 't herwaards komen, als in het wederkeeren.

6.

Item, dat alle de overloopers en slaaven, het zy van wat natien het zoude mogen wezen, zoo van hier, als van Banda, naar datum deze zouden mogen weglopen, weder omme zullen gerestitueerd worden, mits dat men voor yder perzoon zal betalen de waardye van twintig Ryxdaalders tot een vereeringe, en voor een overloper, te weten, een Hollander, 40 Ryxdaalders, dat van beide zyden over en weder zal onderhouden worden, te weten naar dato dezes contracts.

\section{7.}

Item, dat van nu voortaan alle roovinge, en hostile actien aan wederzyden zullen cesseren, op poene, dat men de overtreders als schelmen, en perturbateurs van de gemene ruste, metter dood zal straffen, als ook alle de gene, die daar van kennisse, en wetenschap zullen gehad hebben.

8.

Item, zoo het den nood vereischte, dat gemelde Gouverneur hare hulpe verzogt, ofte van doen hadde, zoo beloven zy lieden naar haar uiterste vermogen, 't zy te water of te lande, zyne E. te assisteren, gehouw en getrouw te wezen.

Alle welke bovengemelde artikelen de voorgenoemde Orang Kaja's van Ceram uit den naam ende van wegen de voorsz. eilanden ende

1 Vgl. hiervóór, bldz. 182. 
steden, voor haar, ende haare onderdaanen, beloven en zweren, gelyk zy zweren en beloven mits dezen, op haren Moshhâf onveranderlyk ende getrouwelyk naar te komen, en by zoo verre zij in eeniger deelen deze bovengeschreven artikelen overtreden, ofte infringeren mogten, zoo geven zy den gemelden Heer Gouverneur, nevens zyne geassocieerden, ende onderdaanen, volkomen magt en authoriteit, dat zy zulx op haare perzoonen, onderdaanen en landen, geweldiger hand mogen verhaalen.

Hier en tegen, beloofd de gemelde Heer Gouverneur haar hier in Amboina vryen handel en pas-cedulle op eenige plaats te verleenen, ouder welke bescherminge zy vry en onbeschadigt van onze schepen zullen mogen gaan ende keeren, en haar in alle geregtigheid onpartydig naar behooren voorstaan, ook de gemelde vrindschap over en weer te onderhouden, en doen onderhouden.

Aldus gedaan en besloten ter goeder trouwe, buiten arg of list, ter presentie ende overstaan van alle de ondergeschrevene Oelisiva's en Oelilima's, in 't Fort van Amboina dezen 23 December A. 1624. Was getekent, 't merk van Orang Kaja Cauwera ${ }^{1}$, 't merk van Orang Kaja Keliwaroe ${ }^{2}$, 't merk van Derus van Deuwon ${ }^{3}$, 't merk van Bali van Kelemala ${ }^{3}$; ter zyden stonden als getuigen 't merk van Capitein Hitoe, en 't merk van Pati Toeban.

Ook verklaren Hatib, Pati van Iha, Senghadji Moessa, mede van Tha, Soeba Tsjina van Moelato ${ }^{*}$, Loenitoeni, radja Nollot ${ }^{5}$, en Goela van Kellewaroe op haren Moshhâf, dat zij volkomen kennisse, ende wetenschap hebben, dat gemelde Gecommitteerden van Ceram volkomen magt hebben van hare superiores, omme met den Heer Gouverneur voornoemd te contracteren, de alliantie betreffende.

Aldus gedaan in 't Kasteel van Amboina dezen 23 December A. 1624.

\section{MOLUKKEN.}

17 Juni 1625. 6

De verklaring van deze overeenkomst is te zoeken in onaangenaamheden, welke Batjan's vorst had met de bewoners van Makian, omdat

1 Deze plaats (?) kan ik niet terecht brengen. Misschien poeloe Kivar.

2 Op Ceram Laoet.

3 Ik kan deze plaatsen niet terecht brengen.

4 Poeloe Marloe of Marlaoet?

5 Op Saparoea.

- Uit het Contractboek. 
deze sagoe kwamen kloppen in zijn gebied. Hij beklaagde zich daarover bij den Nederlandschen gouverneur der Molukken. (Vgl. Onuitgegeven missive van Lefebure aan den G.G. 25 Juli 1626).

Allsoo Batchian met d'omleggende eylanden van dien seer vrughtbaer ende wel versien sijn met menighvulldige sagouboomen, daerdoor de Macquanesen en meer andere dagelyckx coomen, groote quantiteijt van versche sagou maeken ende vervoeren, sonder den Coninck offte eenige van d'onse aen te spreeken offte te kennen, veell min eenige exactie offte tollen daervoor te betalen, daerdoor Sijne May $^{\mathrm{t}}$ verarmt ende de $\mathrm{H}^{\mathrm{n}}$ Meesters ${ }^{1}$, die soo vele jaren dese plaetse tot groote lasten en oncossten hebben onderhouden, geen verlightinge offte soulagiement tot onderhoudt van dit guarnisoen alhier genoten hebben en buijten alle reden is, het selvige langer te gedoogen en toe te staen, maer volgens alle reght en costuymen van landen, plaetsen ende steden sulcx te beletten en te verhinderen, soo veell doenelijck sall wesen,

Soo ist, dat wij, door last van d'Edle $\mathrm{H}^{\mathrm{r}}$ Jaecques le Febure, raedt van Indien, Gouvern ${ }^{\mathrm{r}}$ en directeur over de Molucques, met Syne May ${ }^{t}$ hebben gecontracteerdt en geaccordeert, zoo well tot ontlastinge van d'E. Comp ${ }^{e}$ als tot onderhoudt van den Coninck allhier, dat alle den genen, die van buyten incomen, t'zij Mooren offte vrije luijden, onder sijn gebiet om sagou te macken en deselvige te vervoeren, sullen gehouden wesen aen te spreeken en den Coninck voorschreven te betalen voor sijn gereghtigheijt en toll $10 \mathrm{p}^{\mathrm{r}}$ cento, te weten, d'eene helffte voor Sijn Maij ${ }^{t}$ en d'ander helfft ten proffijte van d'E. $\mathrm{H}^{\text {ren }}$ Meesters, en bij gəbreck offte weijggeringe van dien sij eenige gewelt offte hostiliteijt aen den Coninck toonden, sullen op syn versoeck hem gehouden wesen met eenige soldaten te assisteeren, de prauwen met alle datter in is alles aen te slaen ende te verbeuren ten proffijte van de contracten. ${ }^{2}$ Van gelijcken zullen gehouden en verplight wesen, alle vreemdelingen buijten Comp dienst, die met joncken, correcorren offte eenigh ander vaertuigh van buijten allhier incomen, onder des Conings gebietdt, geladen met eenige waren, 't zij cleeden, padij, olie offte anders, aenspreeken ende vertollen, van gelycke betalende van jncomen tien $\mathrm{p}^{\mathrm{r}}$ cento, d'een helfft ten proffijte van d'E. Compe en dander helft voor den Coninck als vooren, tot naerder ordre ende advoij van d'E. $\mathrm{Ed}^{\mathrm{n}} \mathrm{H}^{\mathrm{r}}$

1 De Bewindhebbers der O. I. C.

${ }^{2}$ Vermoedelijk een schijffout voor: contractanten. 
Gener. 1 En omdat [van] weder zijden alles tot meerder seekerh ${ }^{t}$ te bevestigen en volcomentlijck t'aghtervolgen, hebben twee jnstrumenten gemaeckt van eenen jnhoudt, het eene van ons onderteekent en aen Sijne $\mathrm{May}^{\mathrm{t}}$ overgelevert en het ander met sijn zegell gecacheerdt ${ }^{2}$, en ons behandight, om naer dit gemaeckt contract het sellvige int werck gestelt te werden.

Alldus gedaen op 't eylandt Laboua in Batchian ter vergaderinge van ons, den Coninck met sijnen adell, ady $17^{\mathrm{e}}$ Junij $\mathrm{A}^{\circ} 1625$ en was onderteekent, het eene Gregorij Cornelij ${ }^{3}$ en Lambert Vermeer, ende het andre Nourou Slaedt ${ }^{4}$, coninck van Bachian.

\section{KUST VAN MALABAAR.}

\section{Januari 1626. 5}

$\mathrm{Na}$ het tractaat van 13 October 1608 (hiervóór, no XXU) waren vóór en na betrekkingen met de Westkust van Vóór-Indië, ook met den Samudri van Kalikoet, onderhouden en, ofschoon deze niet van groot gewicht waren, had de O. I. C. toch in die streken twee belangen onder de oogen te zien: den handel met die streken en het feit, dat op die Westkust het centrum was gelegen der Portugeesche macht in het Oosten, Goa.

Den 14 September 1625 ging een eskader onder Herman van Speult, Raad van Indië en oud-gouverneur van Ambon, naar het Westen van Azië, om in vereeniging met andere schepen, ${ }_{n}$ met des te vigoureuser macht de rijcke middelen van de Comp ${ }^{\bullet}$ in voorseijde quartieren, ende haren handel aldaer sonder verhinderinge te verseeckeren. Gelijck mede omme den vijant met een gesignaleerde macht allen mogelijoken af breuck te doen, daer sulex in de voijagie soude mogen voorvallen." " Van Speult kwam in December 1625 te Kalikoet en het.bleek, dat de Samudri oorlog voerde met den vorst van Cochin, in welks rijk de Portugeezen, reeds in 1503, een fort hadden gebouwd, en die steeds in oorlog was met den beheerscher van Kalikoet. (Danvers, Portuguese, I, p. 99). De Samudri ontving Van Speult zeer gastvrij, drong er bij hem op aan dat de Nederlanders een factorij te Kalikoet zouden vestigen en wilde hun het monopolie (o. a. in de peper) schenken, maar de "Moorsche" koop-

1 Gouverneur-generaal.

2 Gecacheteerd.

$s$ Gregorius Corneliszoon of Cornelii was een ambtenaar, Lambert Vermeer waarschijnlijk een officier, in dienst der O. I. C. in de Molukken. (Tiele-Heeres, Bouwstoffen, II, bldz. XL, 43, 119. - Vgl. hiervóór, bldz. 142.)

4 Noer Salat.

${ }^{5}$ Overgenomen uit Valentijn, V, 2 (Malabar), b, bldz. 25, v.

6 Van Speult overleed op dezen tocht den 23 Juli 1626 te Mokka. 
lieden weerhouden dit. Onderstaande voorloopige overeenkomst werd gesloten. (Dagh-Register 1624-1629, bldz. 193, 303; onuitgegeven missive van Van Speult aan den G.G., 15 April 1626.)

Accoort, ofte contract, gemaakt met den doorlugtigen grootmagtigen Keizer van Malabar, en den Koning van Calicoet, etc. ter eenre, en den Edelen Heer Herman van Speult, Raad van Indiën, en gewesen Gouverneur in Amboina, en die van zijnen Raade, commanderende over de schepen en comptoiren van Surata, Persien, en Mocha, wegens de Ed. doorlugtige Hoog Mog. Heeren Staaten Generaal, den Heer Prince van Orangien, etc. ende de Ed. Nederlanse Oostindische Compagnye, onder het beleyd van den Ed. Heer Pieter de Carpentier ${ }^{1}$, ter anderer zyde.

Eerstelyck, zyn beyde de Partyen met den anderen over eengekomen, en verdragen, dat Zyn Majesteit al de Peper, soo onder zyn heerschappy en dominen valt, zal gehouden wesen te doen leveren aan den persoon, die de Ed. Heer Gouverneur voornoemd daar toe nomineren of stellen zal, ten pryse van seven en twintig Realen van agten het Candi ${ }^{2}$, bestaande in vyf honderd en twintig Ponden, te weten, ider Pond tot seventien Spaansche Realen gekoft, wel verstaande, dat de voorsz. Peper ook zuiver en zonder eenige maculen ${ }^{3}$, Valsheyd, of bedrog, behoorlyk gedroogd, en op de bequame tyd geplukt wesen sal.

Ten tweede, dat al de Gember, te weten, grof, schoon en droog, goed, en zyn gemelde Majesteit gehouden wesen zal, die te doen leveren in handen van den voorsz. genomineerden persoon, te weten, 't Candi van vyfhonderd en twintig pond tot elf Realen van achten.

Ten derden, is de conditie, dat de gemelde waaren, als Peper, Gember, en alle andre, zullen vry en vrank zonder eenigs tollen of geregtigheden, hoedanig zy zouden mogen genoemd zyn, te betalen, en dat zy zullen gescheept, en vervoerd werden, zonder eenige contradictie van zyn Majesteit, of andre subalterne Hoofden; van gelyken zullen mede Tolvry, en buiten lasten, soodanige goederen of waaren, van wat quantiteyt en qualiteyt die zouden

1 Gouverneur-Generaal van 1623-1627.

? Candy, een gewicht, nog in het Zuiden van Vóór-Indië gebruikelijk. (Hobson-Jobson, p. 119). - De prijsbepaling is mij overigens niet duidelijk.

s Portugeesch : macula $=$ vlek. 
mogen wesen, zyn, die wy hier aan land zouden mogen brengen, om te verhandelen, of te verkoopen, gelyk mede verstaan werd van alle Provisie en eetbare waaren, die de Compagnyes-dienaars, of gaande en komende schepen, zouden mogen van doen hebben, zonder dat zyn Majesteit imand van zyn onderdaanen, ter oorzake van zulx, of onder wat naam of Titel het zoude mogen wezen, hen lieden zal mogen verhinderen of lastig vallen, waar voor zyn Majesteit toezegt en beloofd werd (soo hast de aggreatie uit het Vaderland, of Batavia, zal gekomen zyn, die gepresumeerd werd binnen anderhalf of twee Jaar ten uitersten hier zal wesen) zal genieten ider Jaar een metaele halve kartouw, van omtrent vier duisend Pond gewicht, en dat in recompense en voldoening van de voorsegde vryheid van Tollen, wel verstaande, dat zulx niet eer zal gegeven werden, als 't Jaar na de approbatie.

Ten vierden beloofd zyn Majesteit, dat hy zal voorkomen, dat geen Peper of Gember zal vercogt of vervoerd werden, als alleen aan onse gecommitteerden wegens de Ed. Nederlandse Oostindische Compagnye, uitsluitende niet alleen alle Portugeesen, Engelsen, Deenen, Franssen, Guzeratten, Persiaanen ', of andere Natien, hoedanig die zouden mogen genaamd wesen, maar ook zyne eigen onderdanen; beloofd daar by neffens, om zulk effect te doen sorteeren, dat niemand van zijn onderdanen zal vermogen, ten tyde als de Peper zal ryp geworden zyn, dezelve by hem te houden, op verbeurte van de voorsz. Peper, en arbitrale correctie van Zyn Majesteit, soo die by gemelde Persoonen sou mogen gevonden werden, tot welken einde zyn Majesteit beloofd, op ons versoek, tydelyk insinuatie te doen, dat by soo verre quam te gebeuren, dat imand bevonden wierd op vervoering van de Peper en Gember, dat de selve niet alleen zal verbeuren de Peper of Gember, maar ook na gelegenheid van saken als een overtreder, en violateur van dit contract, ten exempel van anderen gestraft, zal werden.

Ten vyfden, beloofd zyn Majesteit van gelyken de Gecommitteerden wegens de Ed. Oostindische Nederlandsche Compagnie een goede groote bequaame steene brandvrye wooning in de stad Panani ${ }^{2}$ omtrent de Rivier te versorgen, om de Peper, ende de andre waaren,

1 Het is niet te verwonderen, dat de Moorsche kooplui, onder wie die van Voor-Indië zelf en van Perzië zulk een belangrijke plaats innamen, tegen deze bepaling in verzet kwamen.

2 Ponani, tusschen Kalikoet en Cochin, aan de kust, een belangrijke zeehaven. 
voor brand, en andre ongevallen te bevryden, welke huising wy gehouden sullen zijn alle Jaar tot een redelyke Prys te betaalen, in welke huising, of logie, de onderdaanen van Zyn Majesteit sullen gehouden wesen de Peper, Gember, en alle andre waren, te leveren, en te wegen op hun eigen kosten. Van gelyken beloofd Zyn Majesteit voorsz. Gecommitteerden van de Ed. Nederlandse Oostindische Compagnie, en hunne goederen, onder zyn protectie en bescherminge te nemen voor alle overlast, outrage, en geweld, dat hem sou mogen werden aangedaan.

Ten sesden beloofd Zyn Majesteit, soo 't quam te gebeuren, dat imand van de Ed. Compagnies dienaars door eenig misbruik quam weg te loopen, en onder zyn Majesteits onderdanen op gehouden te werden, soo zal zyn Majesteit in dien gevalle gehouden wesen de selven wederom te doen leveren in handen van den Opperkoopman van de Ed. Nederlandse Compagnie, en of 't gebeurde (dat God verhoede) dat eenig ongeval van doodslag, door toorn of misverstand van de onsen geschiede, soo zal zijn Majesteit, den gemelden delinquant in handen krygende, gehouden zyn dien te leveren in handen van den voornoemden koopman, ten einde hy daar bewaard en geslooten gehouden werde, ter tyd en wyle dat de Ed. Heer Generaal van de misdaad volkomen verwittigt en voldaan is, om als dan na verdienste van saaken gestraft te werden.

Alle welke boven gemelde artikelen en conditien, die beyde de partyen over en weder beloven en zweeren by solemneelen Eede, ider op zyne wyse, te agtervolgen, en te doen onderhouden- voor den tyd van ses agter een volgende Jaaren, wel verstaande, soo zulx by de Ed. Nederlanse Compagnie, of de Ed. Heer Generaal, geapprobeerd, en goedgevonden zal werden binnen den tyd van anderhalf of twee Jaaren, en soo deselve zulx niet approbeeren, zullen de Ed. Compagnies Gecommitteerden met hunne goederen onverhinderd mogen vertrekken, blyvende des niet te min onse vorige Vriendschap in zyne volkomen vigeur en kracht onverminderd.

Aldus gedaan ter goeder trouwe in Schetua ${ }^{1}$, in 's Keizers Huis, desen 3 January $A^{\circ} 1626$.

1 In Van Speult's brief van 15 April 1626 is sprake van Zentuwa, waarheen hij door den Samudri was uitgenoodigd. Deze lag daar toen te velde tegen den vorst van Cochin. Vermoedelijk wordt hiermede bedoeld Chetvai of Chetyai, (ten zuiden van Ponani), toen een plaatsje van eenige beteekenis. 